Prepared in cooperation with the U.S. Army Corps of Engineers

\title{
The Shallow Stratigraphy and Sand Resources Offshore of the Mississippi Barrier Islands
}

Open-File Report 2011-1173

Version 1.1, March 2014

U.S. Department of the Interior

U.S. Geological Survey 
This page has been left blank intentionally. 


\section{The Shallow Stratigraphy and Sand Resources Offshore of the Mississippi Barrier Islands}

By David Twichell, ${ }^{1}$ Elizabeth Pendleton, ${ }^{1}$ Wayne Baldwin, ${ }^{1}$ David Foster, ${ }^{1}$ James Flocks, ${ }^{2}$ Kyle Kelso, ${ }^{2}$ Nancy DeWitt, ${ }^{2}$ William Pfeiffer, ${ }^{2}$ Arnell Forde, ${ }^{2}$ Jason Krick, ${ }^{3}$ and John Baehr

Open-File Report 2011-1173

Version 1.1, March 2014

1U.S. Geological Survey, Woods Hole, MA 2U.S. Geological Survey, St. Petersburg, FL

3 U.S. Army Corps of Engineers, Mobile, AL

U.S. Department of the Interior

U.S. Geological Survey 


\section{U.S. Department of the Interior \\ KEN SALAZAR, Secretary}

\section{U.S. Geological Survey \\ Marcia K. McNutt, Director}

U.S. Geological Survey, Reston, Virginia: 2011

For product and ordering information:

World Wide Web: http://www.usgs.gov/pubprod

Telephone: 1-888-ASK-USGS

For more information on the USGS-the Federal source for science about the Earth, its natural and living resources, natural hazards, and the environment:

World Wide Web: http://www.usgs.gov

Telephone: 1-888-ASK-USGS

Suggested citation: Twichell, David, Pendleton, Elizabeth, Baldwin, Wayne, Foster, David, Flocks, James, Kelso, Kyle, DeWitt, Nancy, Pfeiffer, William, Forde, Arnell, Krick, Jason, and Baehr, John, 2011, The shallow stratigraphy and sand resources offshore of the Mississippi Barrier Islands (ver. 1.1, March 2014): U. S. Geological Survey Open-File Report 2011-1173, at http://pubs.usgs.gov/of/2011/1173/.

(Supersedes ver. 1.0 released August 4, 2011.)

Any use of trade, product, or firm names is for descriptive purposes only and does not imply endorsement by the U.S. Government.

Although this report is in the public domain, permission must be secured from the individual copyright owners to reproduce any copyrighted material contained within this report. 


\section{Contents}

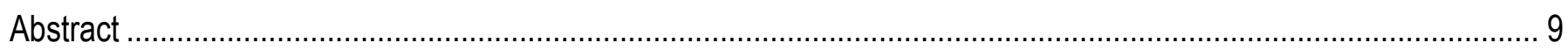

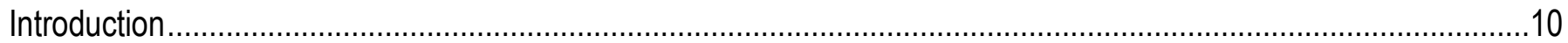

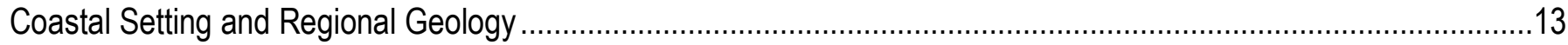

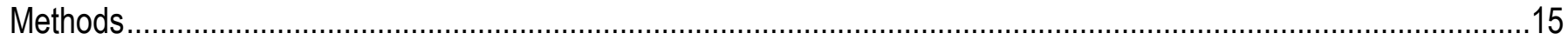

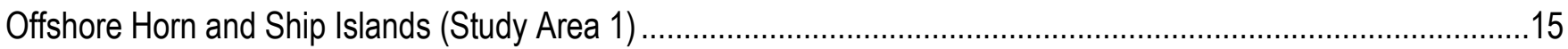

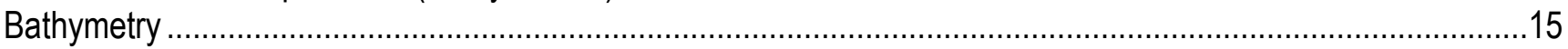

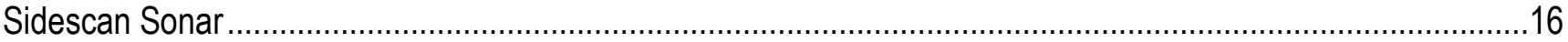

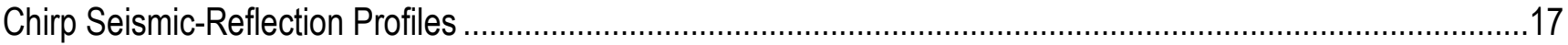

Offshore Petit Bois Pass and Ship Island Pass adjacent to Cat Island (Study Areas 2 and 3) ..............................18

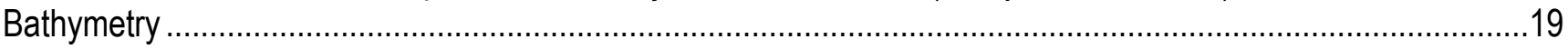

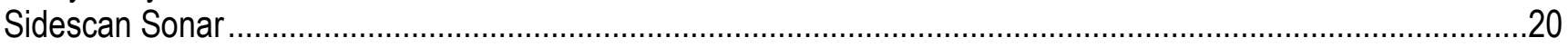

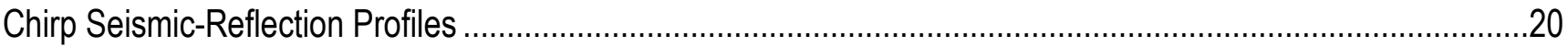

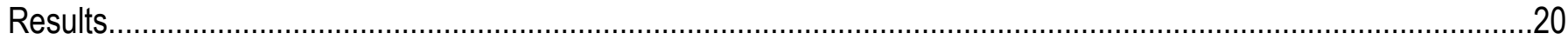

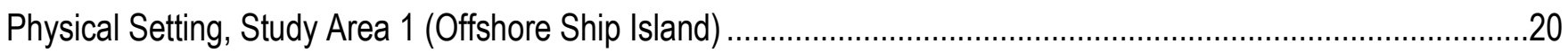

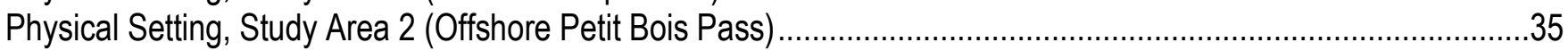

Physical Setting, Study Area 3 (Ship Island Pass at Cat Island) .........................................................................

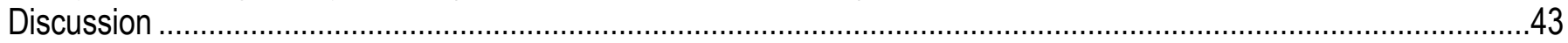

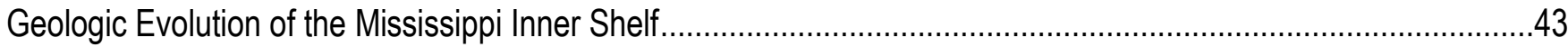

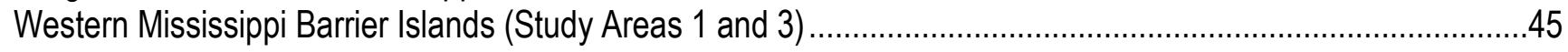

Eastern Mississippi Barrier Islands (Study Area 2) ...............................................................................46

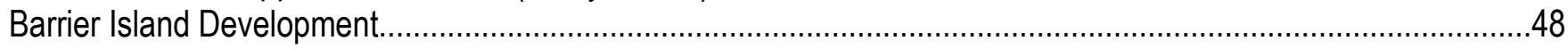

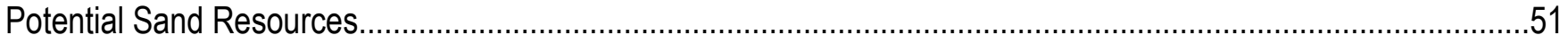

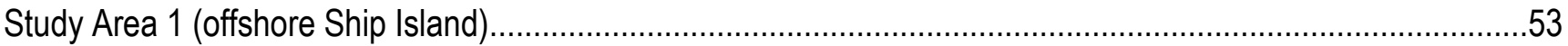

Study Area 2 (Offshore Petit Bois Pass) ………………………………………………………......56

Study Area 3 (Ship Island Pass at Cat Island) ....................................................................................5

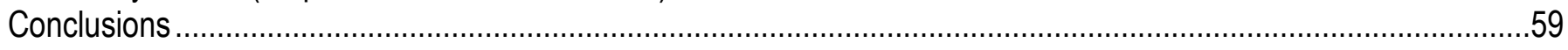

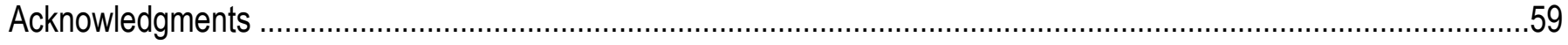

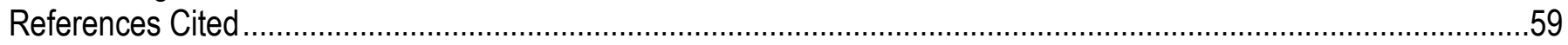

\section{Figures}

Figure 1. Satellite map showing land and inlet features discussed in this report ..................................................11

Figure 2. Map showing the tracklines for geophysical data collected ................................................................12

Figure 3. Location map showing the barrier islands off the Mississippi and Alabama coast. ....................................14

Figure 4. Map showing the distribution of gas within Study Area 1................................................................. 18

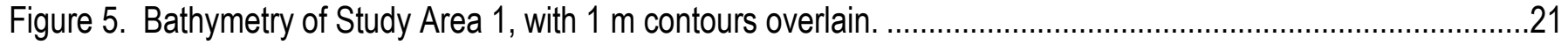

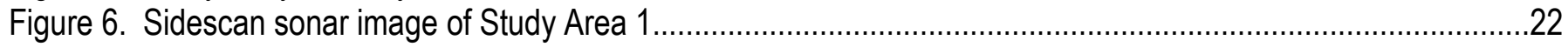

Figure 7. Interpretive map of Study Area 1 showing areas of varying backscatter intensity based on the

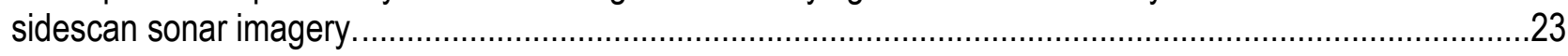

Figure 8. Collapse feature adjacent to dredge spoil mounds on the eastern side of the Gulfport Ship Channel..

Figure 9. Map of Study Area 1 showing the depth to the lowstand surface that was formed during the latest Pleistocene..

Figure 10. Map of Study Area 1 showing the total thickness of Holocene sediment..............................................27 
Figure 11. Chirp profile showing the six units that compose the Holocene sedimentary section in Study Area 1 plus pre-Holocene deposits.

Figure 12. Map showing the distribution and thickness of sediment contained in the valleys in Study Area 1 that were cut during the last lowstand of sea level

Figure 13. Two north-south trending chirp profiles across the buried shoal in Ship Island Pass $(A)$ and the exposed tidal delta off East Ship Island (B).

Figure 14. Map showing the location and thickness of the southern part of the Ship Island Shoal deposit and the tidal delta deposit off East Ship Island.

Figure 15. Seismic profiles showing $(A)$ the acoustically finely laminated nature of the St. Bernard Delta deposits.....

Figure 16. Map showing the distribution of the four Holocene units that are exposed on the seafloor within Study Area 1.

Figure 17. Map showing the distribution of dredge spoil that exceeds $0.5 \mathrm{~m}$ in thickness and seismic profile showing the bathymetric expression and acoustic nature of the deposit.

Figure 18. Bathymetry, in meters below sea level (mbsl), of Petit Bois Pass and offshore shoals (Study Area 2) with profiles of transects A - D.

Figure 19. Isopach perspective (A) and example chirp profile (B) of offshore shoals in Study Area 2.

Figure 20. Bathymetric Digital Elevation Models (DEMs) for three time periods.

Figure 21. Sidescan sonar mosaic of the offshore shoals

Figure 22. Bathymetry of Study Area 3 showing shoals and spoil deposits.

Figure 23. Shaded relief map of Ship Island Pass (Study Area 3) with location and isopach of shoal deposit (hateched area).

Figure 24. Chirp profile across shoal and interpretation show the two units that comprise the shoal

Figure 25. Isopach map of the upper unit of the shoal in Study Area 3.

Figure 26. Conceptual illustration showing the five major steps in the Holocene evolution of the western

Mississippi inner shelf

Figure 27. Trackline locations where buried distributary deposits are identified in Chirp profiles.

Figure 28. Map showing the distribution of the mean-grain size of surface sediment samples contained in the USGS usSEABED database

Figure 29. Locations of potential sand resources identified in this study.

Figure 30. Map showing the distribution and thickness of four potential sand resource targets within Study Area 1.

Figure 31. Isopach perspective of the seaward end of Dog Keys Pass ebb-tidal delta in Study Area 1

Figure 32. Isopach map of Ship Island Pass Shoal, interpreted from Chirp profiles

Figure 33. Regional shaded-relief perspective surrounding Study Area 2

Figure 34. Chirp profile (top) and vibracores along a transect within Mississippi Sound....

\section{Table}

Table 1. Characteristics of potential sand-resource deposits located on the shelf offshore of the barrier islands off the western Mississippi coast 


\section{Conversion Factors and Acronyms}

\begin{tabular}{lcl}
\multicolumn{1}{c}{ SI to Inch/Pound } & \multicolumn{1}{c}{ By } & \\
\hline & Length & \\
\hline centimeter $(\mathrm{cm})$ & 0.3937 & To obtain \\
millimeter $(\mathrm{mm})$ & 0.03937 & inch (in.) \\
meter $(\mathrm{m})$ & 3.281 & foot $(\mathrm{ft})$ \\
kilometer $(\mathrm{km})$ & 0.6214 & mile $(\mathrm{mi})$ \\
\hline & Area & \\
\hline square kilometer $\left(\mathrm{km}^{2}\right)$ & 0.3861 & square mile $\left(\mathrm{mi}^{2}\right)$ \\
\hline & Volume & \\
\hline cubic meter $\left(\mathrm{m}^{3}\right)$ & 35.31 & cubic foot $\left(\mathrm{ft}^{3}\right)$ \\
cubic meter $\left(\mathrm{m}^{3}\right)$ & 1.308 & cubic yard $\left(\mathrm{yd}^{3}\right)$ \\
cubic kilometer $\left(\mathrm{km}^{3}\right)$ & 0.2399 & cubic mile $\left(\mathrm{mi}^{3}\right)$ \\
\hline & Flow rate & \\
\hline meter per second $(\mathrm{m} / \mathrm{s})$ & 3.281 & foot per second $(\mathrm{ft} / \mathrm{s})$ \\
\hline
\end{tabular}

Specific conductance is given in microsiemens per centimeter at 25 degrees Celsius $\left(\mu \mathrm{S} / \mathrm{cm}\right.$ at $\left.25^{\circ} \mathrm{C}\right)$. 


\section{Acronyms}

\begin{tabular}{ll} 
ASCII & American Standard Code for Information Interchange \\
DEM & digital elevation model \\
DGPS & Differential Global Positioning System \\
ETD & ebb-tidal delta \\
FSSB & Full Spectrum Sub-Bottom \\
GUIS & Gulf Islands National Seashore \\
HSX & HYPSWEEP raw data format \\
IMU & Internal Motion Unit \\
MAFLA & Mississippi-Alabama-Florida \\
MBMAX & HYPSWEEP's Multibeam Max editor \\
Mbsl & meters below sea level \\
MLLW & mean lower low water \\
MsCIP & Mississippi Coastal Improvement Project \\
NAVD 88 & North American Vertical Datum of 1988 \\
NGDC & National Geophysical Data Center \\
NGOM & Northern Gulf of Mexico \\
NOAA & National Oceanic and Atmospheric Administration \\
OSL & Optically Stimulated Luminescence \\
SEG Y & Society of Exploration Geophysicists Y \\
SIPS & Sonar Information Processing System \\
SOS & Speed of sound \\
SVP & Sound velocity probe \\
SVS & Sound Velocity Sensor \\
SXC & SEA Swath Processor Coverage File \\
SXR & SEA Swath Processor Raw File \\
USACE & U.S. Army Corps of Engineers \\
USGS & U.S. Geological Survey \\
WGS84 & World Geodetic System 84 \\
XTF & Extended Triton Forma \\
\hline ST &
\end{tabular}




\section{The Shallow Stratigraphy and Sand Resources Offshore of the Mississippi Barrier Islands}

By David Twichell, Elizabeth Pendleton, Wayne Baldwin, David Foster, James Flocks, Kyle Kelso, Nancy DeWitt, William Pfeiffer, Arnell Forde, Jason Krick, and John Baehr

\section{Abstract}

Coastal Mississippi is protected by a series of barrier islands ranging in length from 10-25 kilometers that are less than 2 kilometers wide. The majority of these islands comprise the Gulf Islands National Seashore (GUIS), an ecologically diverse shoreline that provides habitat for wildlife including migratory birds and endangered animals. The majority of GUIS is submerged, and aquatic environments include dynamic tidal inlets, ebb-tide deltas, and seagrass beds. The islands are in a state of decline, with land areas severely reduced during the past century by storms, sea-level rise, and human alteration. Morton (2008) estimates that since the mid-1800s up to 64 percent of island surface area has been lost. Heavy damage was inflicted in 2005 by Hurricane Katrina, which passed by as a Category 3 storm and battered the islands with winds of more than 160 kilometers per hour and a storm surge up to 9 meters.

Since 2007, the U.S. Geological Survey (USGS), in collaboration with the National Park Service, has been mapping the seafloor and substrate around the islands as part of the USGS Northern Gulf of Mexico Ecosystem Change and Hazard Susceptibility project. The purpose of these investigations is to characterize the near-surface stratigraphy and identify the influence it may have on island evolution and fate. In 2009, this effort provided the basis for a collaborative effort with the U.S. Army Corps of Engineers (USACE) to expand the investigation outside of GUIS boundaries as part of the Mississippi Coastal Improvement Project (MsCIP). The MsCIP program consists of structural, nonstructural, and environmental project elements to restore portions of coastal Mississippi and GUIS affected by storm impact. The project includes the placement of sand along the islands, both on the present beaches and within the littoral zone, to mitigate shoreline erosion and breaching. This action requires the location and assessment of offshore sand or sediment deposits that can provide suitable material for shoreline renourishment. The geophysical and sample information collected by the USGS during geologic investigations provides this information.

As part of the MsCIP program, in March 2010 the USGS mapped approximately 300 square kilometers of seafloor around GUIS. Interferometric swath bathymetry, sidescan sonar, and Chirp sub-bottom profiling were used to characterize seafloor elevations, texture, and the underlying stratigraphy. On the basis of this information, potential sediment resources were identified. The most promising offshore deposits for beach restoration include shoals, lowstand valley fill, tidal delta deposits, abandoned barrier deposits, and dredge spoil. Of these, lowstand valley fill deposits and dredge spoil are less desirable; lowstand deposits are buried under a 2- to 4-meter blanket of mud, and dredge spoil volume is small. A relict tidal delta and submerged shoals are the most desirable deposits; the tidal delta contains a large volume of material still exposed on the seafloor, and parts of submerged shoals have modest volume and thin mud cover. 


\section{Introduction}

The Mississippi Sound barrier islands are Dauphin, Petit Bois, Horn, East Ship, West Ship, and Cat (fig. 1). Major inlets within the island system are Petit Bois Pass, Horn Island Pass, Dog Keys Pass, Camille Cut, and Ship Island Pass. The islands have eroded, and the passes widened, significantly over historical time (Otvos, 1970; McBride and others, 1995; Morton, 2008), and the long-term fate of this critical habitat is uncertain. Rising sea level, severe storms, and engineering activities (for example, dredging of shipping channels) all threaten their sustained subaerial presence. Perhaps the most visible impacts that have occurred during historical time are the repeated breaches caused by hurricanes on Dauphin and Ship Islands (Morton, 2008; Flocks and others, 2011). A particularly problematic breach that cut through Ship Island in 1969 during Hurricane Camille split the island into distinct eastern and western segments. This breach, called Camille Cut (fig. 1), widened significantly during Hurricane Georges in 1998. Hurricane Katrina in 2005 had a particularly heavy impact on East Ship Island (Morton, 2010) and widened the breach further. Concerns over damage to National Park Service infrastructure on Ship Island and the likelihood of increased damage to coastal communities shoreward of the islands during future storms resulted in the development of a comprehensive coastal improvement plan for the Mississippi coast (U.S. Army Corps of Engineers, 2009). One aspect of this plan proposes filling Camille Cut.

The U.S. Geological Survey (USGS), in collaboration with the U.S. Army Corps of Engineers (USACE), mapped much of the inner shelf offshore of the Mississippi barrier islands in order to define the shallow stratigraphy of the region and assess the distribution and extent of sediment deposits that could be mined for the large volume of material needed to fill Camille Cut. Geophysical data collected by the USGS and vibracores collected by the USACE were integrated to provide a detailed understanding of the regional shallow stratigraphy and the lithology of its various units. The navigation tracklines and core locations are shown in figure 2. This report summarizes the results of the data collected. For clarity the main features are separated into three Study Areas: (1) seaward of Ship Island, (2) seaward of Petit Bois Pass, and (3) Ship Island Pass at Cat Island. 


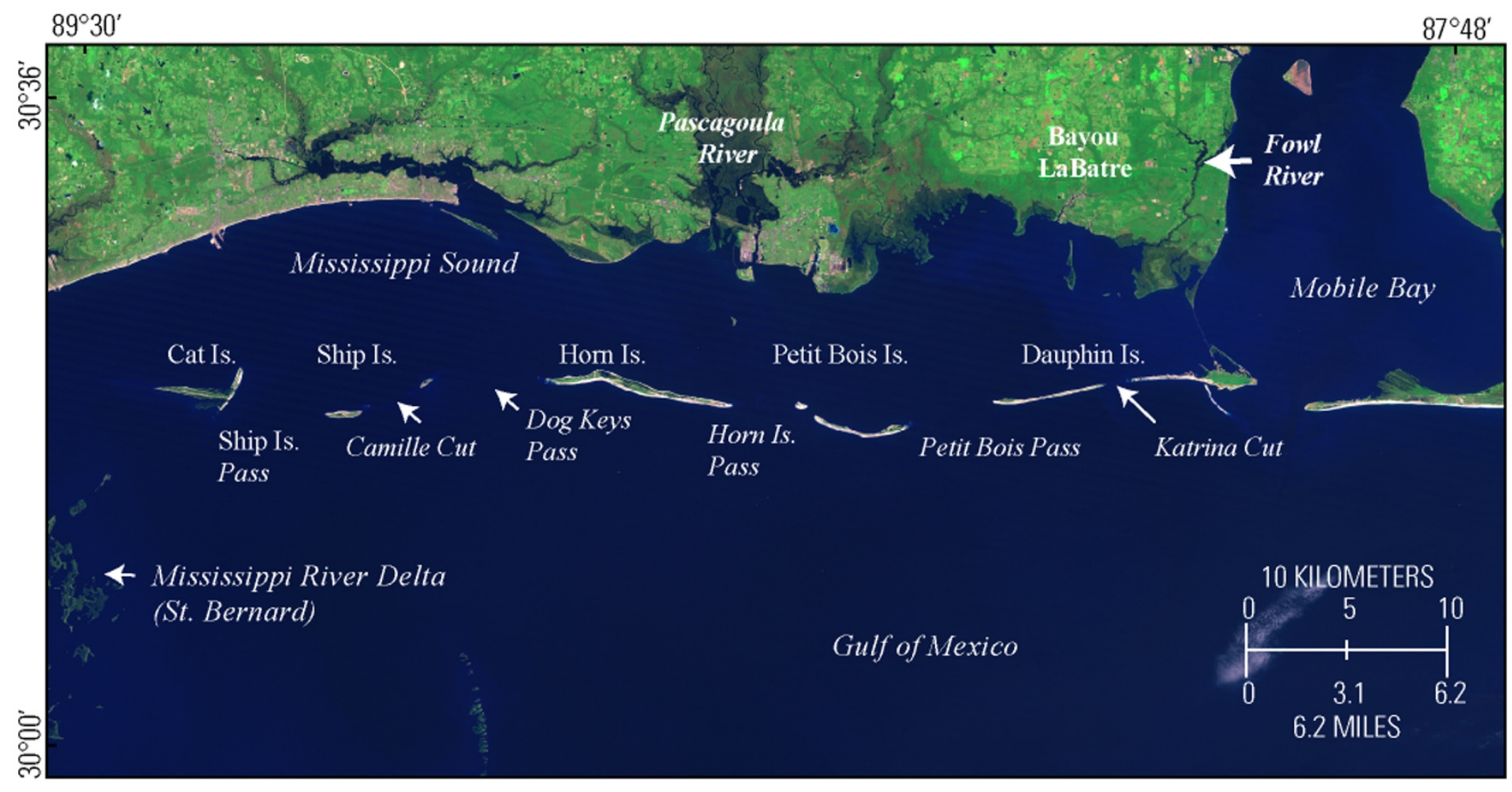

Figure 1. Satellite map showing land and inlet features discussed in this report. The islands of Petit Bois, Horn, Ship (East and West), Cat (western part), and surrounding waters comprise the Gulf Islands National Seashore (GUIS). 


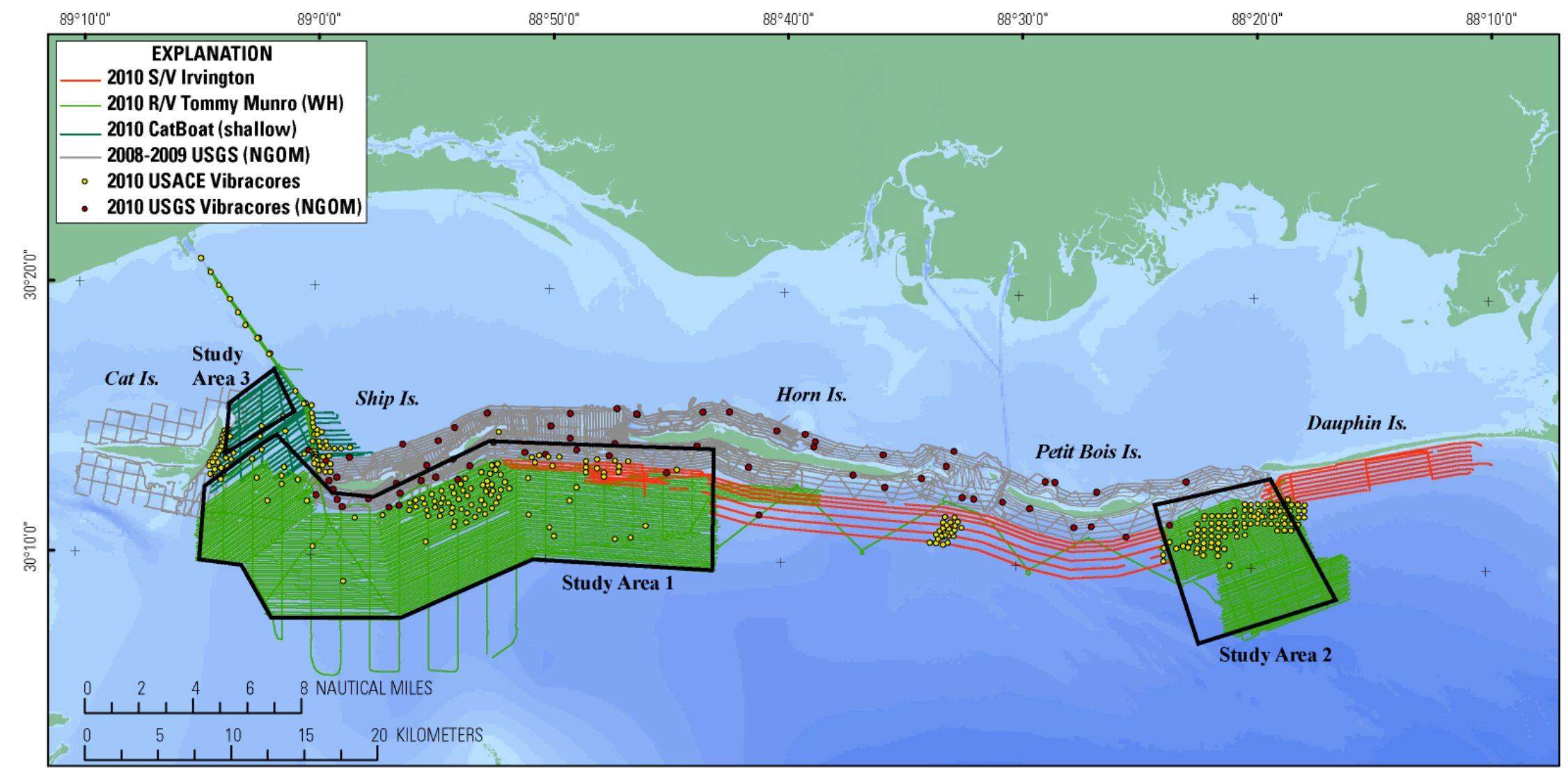

Figure 2. Map showing the tracklines for geophysical data collected. Vibracores collected by the USACE for the MsCIP project and the USGS for the Northern Gulf of Mexico (NGOM) project are shown. Main features were separated into three Study Areas. 


\section{Coastal Setting and Regional Geology}

The barrier islands offshore of the Mississippi coast include Petit Bois, Horn, East Ship, West Ship, and Cat Islands (fig. 1). The major passes between the islands (Petit Bois Pass, Horn Island Pass, Dog Keys Pass, and Ship Island Pass) have existed throughout historical time, but Camille Cut, which separates East and West Ship Islands, initially formed in 1969 during Hurricane Camille and has widened during more recent hurricanes (Georges in 1998 and Katrina in 2005; Morton, 2008). Petit Bois Pass originated at the turn of the $19^{\text {th }}$ century, when a hurricane breached Dauphin Island. The western remnant of Dauphin Island became Petit Bois Island. Two of these passes, Horn and Ship, have ship channels dredged through them.

The islands stand 11-20 kilometers (km) offshore of the mainland coast and form the seaward edge of Mississippi Sound. They are part of a longer island chain that initially formed about 4,000-5,000 years before present (yr B.P.) and extended from the mouth of Mobile Bay westward to New Orleans (fig. 3, inset; Otvos, 1981; Stapor and Stone, 2004). The eastward advance of the St. Bernard Delta from the Mississippi River and the southward advance of the Pearl River Delta largely buried the islands west of Cat Island by approximately 2,000 yr B.P. (Otvos and Giardino, 2004). Once the St. Bernard Delta was abandoned, coastal processes reworked the sandy components of its seaward edge to form the Chandeleur Islands. The northern extent of these islands is about $20 \mathrm{~km}$ south of East Ship Island. The "T" shape of Cat Island has been attributed to a response in shoreline orientation to the change in wave approach angle caused by advance of the St. Bernard Delta and formation of the Chandeleur Islands (Rucker and Snowden, 1989). The topographic influence of the St. Bernard Delta is reflected in the bathymetry of the inner shelf. The seafloor gradient is greatest offshore of Petit Bois Island, where it dips at a slope of 2 meters per kilometer $(\mathrm{m} / \mathrm{km})$ to the south. To the west, off Cat Island, the seafloor slope is gentler and dips at $0.4 \mathrm{~m} / \mathrm{km}$ to the southeast. The change in seafloor slope and dip orientation is the result of the eastward advance of the St. Bernard Delta (fig. 3, inset).

During the last lowstand of sea level (20,000-10,000 yr B.P.), rivers incised a dense network of valleys into the exposed shelf surface. As sea level rose, the valleys were flooded and filled with a mixture of sand and muddy deltaic and estuarine deposits (8,000-5,000 yr B.P.). With the continued rise in sea level, a thin $(<4 \mathrm{~m})$ blanket of mud and sandy mud was deposited across large parts of this flooded shelf prior to the formation of the Mississippi barrier islands ( 5,000 yr B.P.). These islands and the intervening shoals and tidal deltas initially stood seaward of their present location. During the eastward advance of the St. Bernard Delta (4,000-2,000 yr B.P.), the western part of the shelf and barrier islands (Cat and West Ship Islands) was largely buried by prodeltaic mud. Once this delta was abandoned and the Mississippi River redirected deltaic sedimentation farther south, the barrier islands continued to retreat shoreward, and parts of the original barrier island and a tidal delta were left stranded on the inner shelf (2,000 yr B.P. to present). Finally, dredging of the Gulfport Ship Channel has resulted in the local redistribution of sediment on the shelf. 


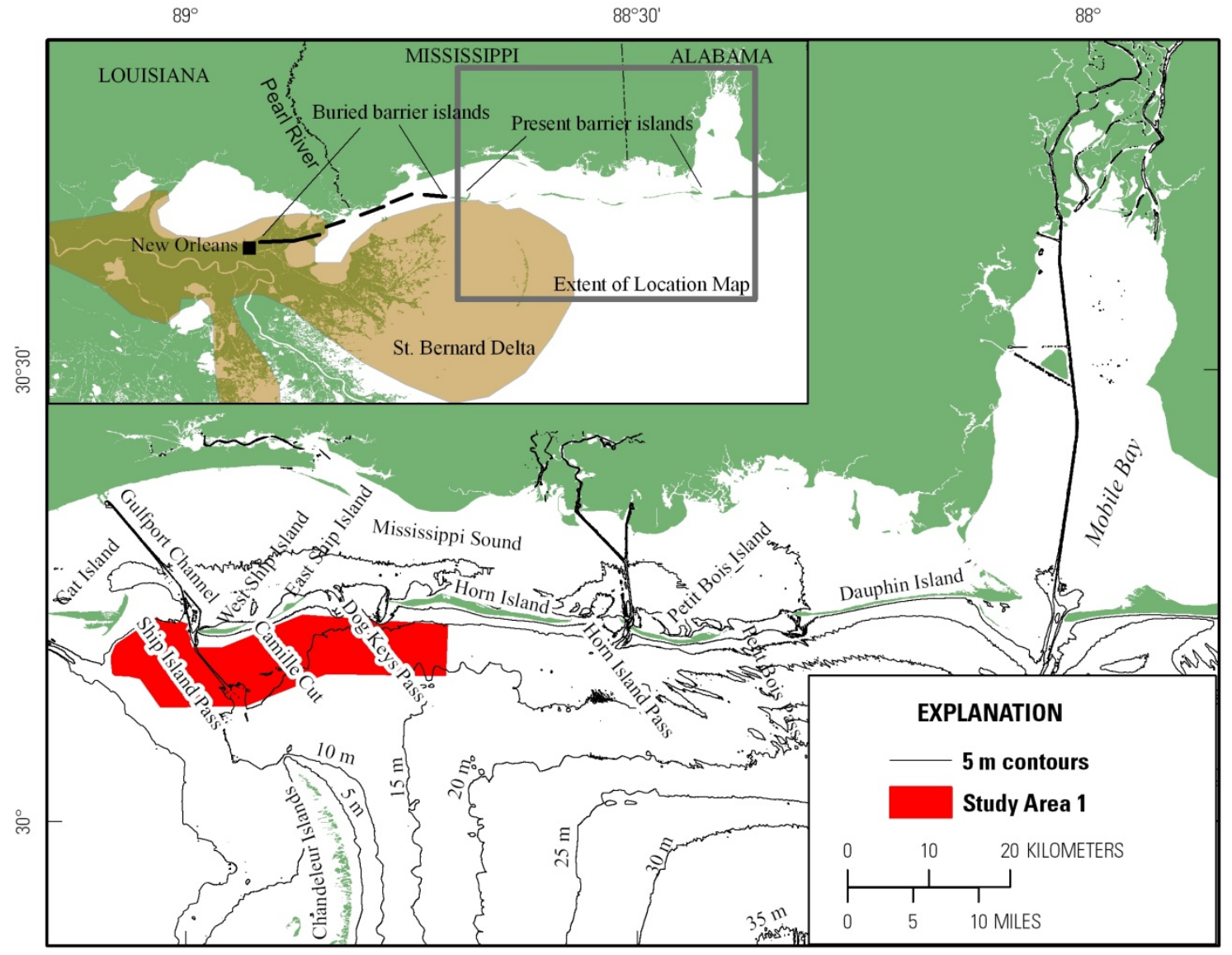

Figure 3. Location map showing the barrier islands off the Mississippi and Alabama coasts. The focus of Study Area 1 is the area highlighted in red. Inset map shows the extent of the original barrier island chain that extended westward to New Orleans. The black dashed line shows the portion that was buried by the Pearl River and St. Bernard Deltas. The extent of the St. Bernard Delta is shown by the tan color (modified from Otvos and Giardino, 2004). 


\section{Methods}

In-depth explanations of the equipment and processing steps used to produce the data used in this report are given by Pendleton and others (2011), Forde and others (in press), and Pfeiffer and others (2011). These publications represent the formal USGS archives of geophysical data collected for the MsCIP project. Here we provide just a summary of the tools and processing techniques.

Approximately 300 square kilometers $\left(\mathrm{km}^{2}\right)$ of the inner continental shelf offshore of the Mississippi barrier islands were surveyed in March 2010 (fig. 2). In general the surveys focused on three areas: Offshore of Ship Island (Study Area 1), offshore of Petit Bois Pass (Study Area 2), and within Ship Island Pass, adjacent to Cat Island (Study Area 3). Three vessels were used during the collection of data: the large offshore sections were acquired aboard the University of Southern Mississippi research vessel (R/V) Tommy Munro. Additional data were collected offshore in April 2010 onboard the USACE survey vessel (S/V) Irvington. The area within Ship Pass Shoal was surveyed in March 2010 using a small, shallow-draft USGS boat. Interferometric-sonar, sidescan-sonar, and Chirp seismic-reflection systems were deployed simultaneously during each leg. The survey areas are adjacent to GUIS waters that were surveyed by the USGS in 2008 and 2009 (fig. 2). Geographic location of the ship and geophysical systems were determined using Differential Global Positioning System (DGPS) navigation. During acquisition, the vessels maintained speeds between 1.5 and 2.5 meters per second $(\mathrm{m} / \mathrm{s})$. The survey legs are described below.

\section{Offshore Horn and Ship Islands (Study Area 1)}

Data were collected along approximately $2,000 \mathrm{~km}$ of tracklines spaced approximately $150 \mathrm{~m}$ apart in the shore-parallel direction and about $2 \mathrm{~km}$ apart in the shore-perpendicular direction (fig. 2). Shore-parallel trackline spacing was chosen to ensure overlap of at least 10 percent on adjacent sidescan sonar swaths. Shore-perpendicular tracklines were chosen to facilitate internal comparison and correlation of bathymetric and Chirp seismic-reflection data with shore-parallel versus shoreperpendicular orientations.

All three data types were not acquired along the entire length of the tracklines. During the first leg of the cruise, interferometric-sonar, sidescan-sonar, and Chirp seismic-reflection data were acquired along 1,321 km, 1,332 km, and 1,523 km of trackline, respectively. During the second leg, approximately $445 \mathrm{~km}$ of sidescan-sonar data, $455 \mathrm{~km}$ of bathymetric data, and $492 \mathrm{~km}$ of sub-bottom data were collected within the survey area. Data gaps resulted from system malfunctions caused by rough sea state, and subsequent survey-time considerations (for example, sidescan-sonar and bathymetric data were not acquired over several shore-perpendicular lines, in order to increase vessel speed).

\section{Bathymetry}

Bathymetric data were acquired using a 234-kilohertz $(\mathrm{kHz})$ Systems Engineering and Assessment, Ltd. (SEA, Ltd.) Swathplus interferometric sonar during the first leg, and a 468-kHz SEA Ltd. Swathplus interferometric sonar during the second leg. The instrument was mounted on a rigid pole, along the starboard side of the vessel, about $2.5 \mathrm{~m}$ below the sea surface. A DGPS antenna was mounted directly above the sonar head. Swathplus acquisition software was used to fire the system at a 0.25 -second (s) ping rate and digitally log the data at a $1,500-\mathrm{kHz}$ sample rate (Systems Engineering and Assessment, Ltd., 2011). Ship motion (heave, pitch, roll, and yaw) was recorded continuously with a Coda Octopus F180 attitude and positioning system during the first leg and a Coda Octopus F190 attitude and positioning system equipped with Omnistar HP during the second leg (Coda Octopus 
Group, Inc., 2011). Sound-velocity profiles were acquired approximately once every 8 hours (h) during each survey using an AML Oceanographic SV Plus Sound Velocimeter (AML Oceanographic, 2011).

The interferometric sonar system acquired bathymetric soundings over swath widths ranging from 20-115 m, in water depths between 3 and $16 \mathrm{~m}$. Data gaps resulted between adjacent swaths because tracklines were planned to optimize seafloor coverage with the towed sidescan-sonar system, which achieved consistent swath widths of $200 \mathrm{~m}$ during the first leg and 100-200 $\mathrm{m}$ during the second leg. Consequently, bathymetric data gap widths ranged from $0-100 \mathrm{~m}$ and varied as a function of water depth. Accordingly, swath bathymetric data were acquired over approximately 40-50 percent of the entire survey area.

Swathplus acquisition software and CARIS (2011) swath bathymetry processing software were used to process the bathymetric soundings. Navigation data were inspected and edited, sounding data were rectified for ship motion, and spurious soundings were eliminated. Corrections for sound-velocity changes within the water column (sound-velocity profile data) and tidal offsets (utilizing a National Oceanic and Atmospheric Administration (NOAA) discrete tidal zoning model and tidal observations from two Mississippi tide stations) were also applied to the raw soundings. Processed soundings were referenced to mean lower low water (MLLW). The difference between North American Vertical Datum of 1988 (NAVD 88) geoid height and MLLW at the Gulfport Harbor, Miss., and Bay Waveland Yacht Club, Miss., tidal stations is 13.0 and 9.9 centimeters $(\mathrm{cm})$, respectively, and is within the vertical resolution of the interferometric sonar. Processed soundings yielded a final bathymetric surface area of about $265 \mathrm{~km}^{2}$, which was gridded at a resolution of $50 \mathrm{~m}$ per pixel.

\section{Sidescan Sonar}

Sidescan-sonar (acoustic backscatter) data were acquired during the first leg using a Klein 3000 dual-frequency sidescan-sonar system (100 and $500 \mathrm{kHz})$, which was towed approximately $3 \mathrm{~m}$ astern from a starboard-side davit (Klein Associates, Inc., 2011). During the second leg, data were acquired using a Klein L3900 dual-frequency sidescan-sonar system (445 and 900 kHz). Klein SonarPro acquisition software was used on both legs to log the data digitally at a sample rate resulting in raw pixel resolutions of approximately 0.18 and $0.14 \mathrm{~m}$ in the across-track and along-track directions, respectively. Horizontal offset values between the sidescan-sonar towfish and DGPS antenna were entered into the SonarPro software, which calculated towfish position dynamically during acquisition. The Klein systems produced usable data over swath widths of $200 \mathrm{~m}$ during the first leg, and swath widths between 100 and $200 \mathrm{~m}$ during the second leg.

XSonar/ShowImage software was used to correct for geometric and radiometric distortions in the raw sidescan sonar data (Danforth, 1997) and PCI Geomatica software was used to create georeferenced mosaics of the final processed data. Gray-scale GeoTIFF images of the mosaics were produced at 1- and 5-m resolutions. The total area imaged with sidescan sonar was approximately $260 \mathrm{~km}^{2}$. 


\section{Chirp Seismic-Reflection Profiles}

Approximately 2,015 km of high-resolution Chirp seismic-reflection profiles were collected using an EdgeTech Geo-Star Full Spectrum Sub-Bottom (FSSB) system and SB-0512i towfish (0.5-12 kHz) (EdgeTech, 2011). During the first leg, SonarWiz.MAP +SBP acquisition software (Chesapeake Technology Inc., 2011) was used to control the Geo-Star topside unit and digitally log trace data in the Society of Exploration Geophysicists Y (SEG Y), revision 1, standard format (Norris and Faichney, 2002). The SB-0512i towfish was mounted on a catamaran and towed astern of the starboard side of the vessel. Navigation coordinates were obtained from a DGPS antenna mounted on the catamaran and logged to the SEG Y trace headers. Data were acquired using a $0.5-$ to $8-\mathrm{kHz}$ frequency sweep, 5-millisecond (ms) pulse length, 0.25-s shot rate, 46-microsecond ( $\mu \mathrm{s})$ sample interval, and a 100-ms record length. During the second leg, EdgeTech DISCOVER acquisition software was used to control the Geo-Star topside unit and digitally log trace data in the SEG Y, revision 1, standard format (Barry and others, 1975). The SB-0512i towfish was towed astern of the vessel approximately $3 \mathrm{~m}$ below the water surface. DGPS navigation coordinates were obtained from the Coda Octopus F190 attitude and positioning system antenna and logged to the SEG Y trace headers. Data were acquired using a $0.5-$ to $8-\mathrm{kHz}$ frequency sweep, a 5-ms pulse length, 0.25 -s shot rate, a 46- $\mu$ s sample interval, and a 100-ms record length.

SIOSEIS (SIOSEIS, 2011), Seismic Unix (Stockwell and Cohen, 2007) and SeisVision (Halliburton, 2008) were used to post-process the raw Chirp seismic-reflection data. Navigation data were inspected and edited, static corrections were applied to correct for fish depth beneath the sea surface, seafloor reflections were identified by peak amplitude, and sea-surface heave was removed. Final trace data were plotted as PNG images for digital viewing and printing. For digital interpretation, SEG Y trace data were imported into SeisVision, where key reflectors representing the seafloor and other subsurface stratigraphic contacts were identified and digitized. The interpretations were exported from SeisVision as XYZ point files and imported into ArcMap (ESRI, 2011), where surfaces of the interpreted horizons were interpolated and gridded. A 1,500 m/s speed of sound was used to convert the vertical scale of the seismic data from milliseconds of two-way travel time to depths in meters. Grid surface calculations were used to compute the thickness and volume of different stratigraphic units. Gas was extensive in the sediment under much of the western part of Study Area 1 and limited the interpretation of deeper horizons (fig. 4). 


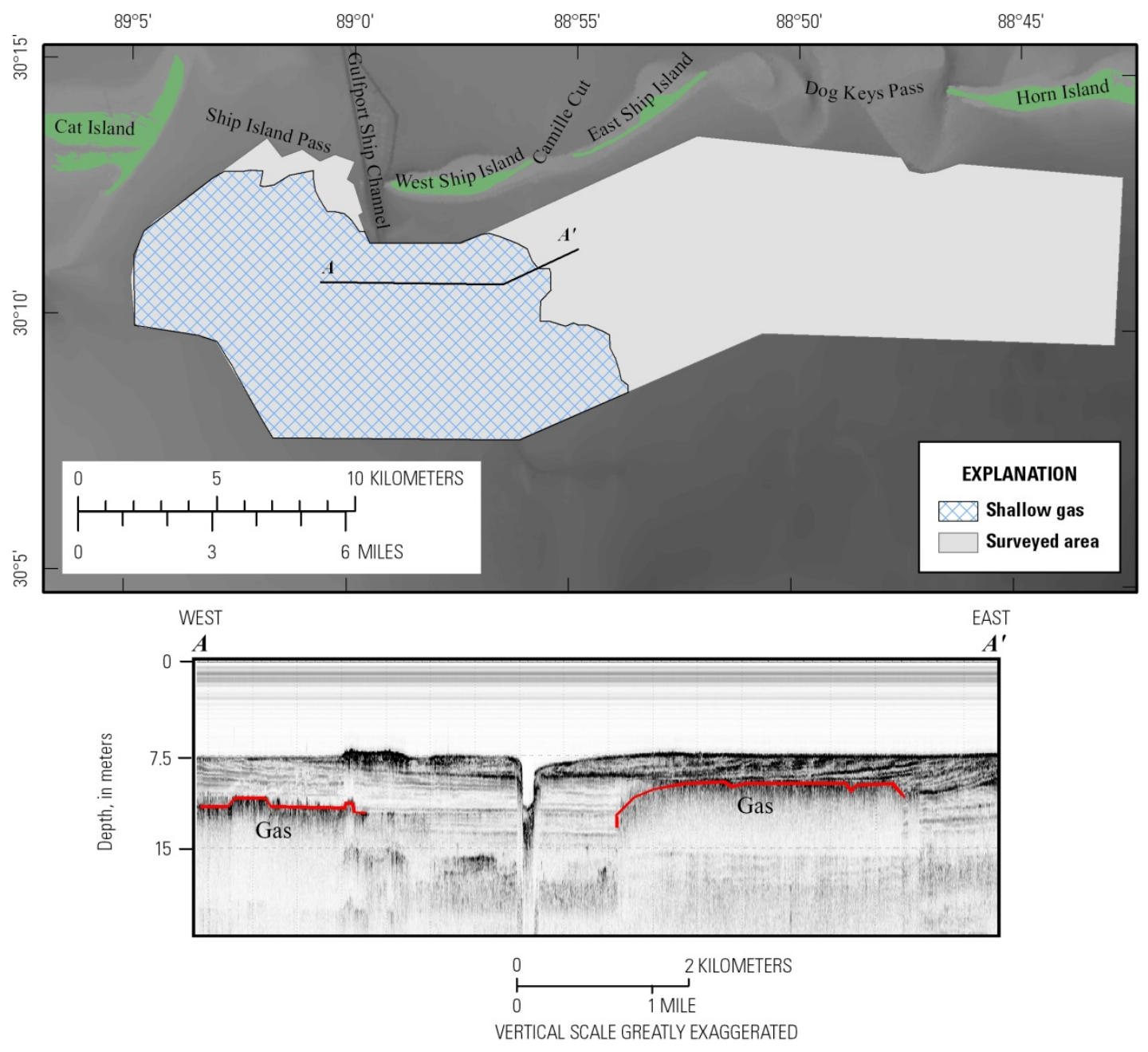

Figure 4. Map showing the distribution of gas within Study Area 1 and seismic profile showing the effect that gas has on the acoustic signal. Zero (0) on the vertical scale of the seismic profile is relative to the sea surface.

\section{Offshore Petit Bois Pass and Ship Island Pass adjacent to Cat Island (Study Areas 2 and 3)}

In Study Area 2, geophysical data were collected using the R/V Tommy Munro. In the shallow waters adjacent to Cat Island (Study Area 3), the USGS 8-m Glacier Bay catamaran with twin 115-horsepower (hp) outboard engines was used as a platform. Elsewhere the data were collected using the USACE S/V Irvington catamaran. The equipment and deployment methods for each platform were the same, except the interferometric swath system was pole-mounted on the starboard side of the R/V Tommy Munro and rail-mounted between the keels of the Glacier Bay catamaran. A multibeam bathymetry system was used on the R/V Irvington with the pole mounted between the keels. 


\section{Bathymetry}

The swath bathymetry was collected using the 468-KHz SEA Ltd. Swathplus-H Interferometric system and SEA Swath Processor software version 3.6. Vessel motion was recorded using a CodaOctopus Octopus F190 precision and attitude positioning system's sensor and antennae. Differentially corrected positions were supplied from OmniSTAR and recorded by the Octopus F190 and output in the World Geodetic System 84 (WGS84) datum. A Valeport Mini Sound Velocity Sensor (SVS) was attached to the transducer head to supply speed of sound (SOS) measurements simultaneously. The SEA Swath Processor Session File SXS used during setup and calibration was used during the survey to record all streaming data into the SEA Swath Processor Raw File (SXR) format and the SEA Swath Processor Coverage File (SXC) format. During the survey, three SOS casts were measured using a Valeport Mini sound velocity probe (SVP) and recorded manually. All data were backed up digitally onto Blu-ray media and terabyte servers. The swath bathymetry was post-processed using SEA Swathplus version 3.07 and edited using CARIS HIPS/SIPS. In CARIS, the Load Tide feature was implemented to reference the swath bathymetry measurements to MLLW using a tide zone model and verified tide data from two tide stations: Pascagoula, Miss., station ID 8741533 and the Gulfport, Miss., station ID 8745557. The tidal zone definition was created and supplied by NOAA. All files were then merged to apply all corrections.

The multibeam bathymetry was collected aboard the S/V Irvington using the RESON SeaBat 8125 System. This system uses a frequency of $455 \mathrm{kHz}$ with a maximum swath angle of 120 degrees. The Applanix POS MV provided boat motion from the Internal Motion Unit (IMU) and heading from the Novatel 531 Choke Ring antennas. GPS for navigation was acquired using the Trimble DSM 212 antenna with a beacon receiver. The Trimble antenna received the broadcasted correction from the NGS CORS reference beacons (Mobile, Ala., and English Turn, La.), which provided the differential navigation at 1 pings per second for multibeam operations. HYPACK, Inc. HYPSWEEP version 10 was used for the multibeam data acquisition, system calibration, and data post-processing. A patch test was performed at the beginning of the survey to calibrate the SEABAT 8125 and included latency, roll, pitch, and yaw. This involved collecting multibeam data along lines over a sloping surface for the latency, pitch, and yaw tests and over a flat surface for the roll test. All multibeam lines were collected in HYPSWEEP raw data format (HSX). The HSX lines were imported into the patch test module of HYPSWEEP's Multibeam Max editor (MBMAX) and converted into HYPSWEEP edited binary file formats (HS2). The resulting offsets from the patch test were applied to the hardware configuration file prior to survey data acquisition. The Applanix POS MV is not a gyro and therefore did not need calibration. During data acquisition, the differentially corrected positions supplied through the Trimble DSM 212 interface were recorded in the WGS84 datum. Ship heading and motion (roll, pitch, heave) were measured by the Applanix POS MV motion unit. Sound velocity was recorded at the multibeam sonar head. Additional sound-velocity casts were conducted at the start and finish of each survey day and as needed throughout the survey. All respective data strings were captured and streamed in real time via HYSWEEP onto a Dell 690 precision shipboard computer. Multibeam data post-processing was completed at the USACE in Mobile, Ala., using HYPACK Inc., HYSWEEP version 10. The raw HSX data files were imported into MBMAX editor for post-processing. Data for tide correction were obtained from automated tide gages maintained by the USACE and applied at this point within MBMAX. The sound velocity cast data were also applied in MBMAX at this point. The processed XYZ data files were exported in American Standard Code for Information Interchange (ASCII) format and referenced to WGS84 for the horizontal datum and MLLW for the vertical datum. 


\section{Sidescan Sonar}

A Klein 3900 dual-frequency sidescan sonar system was towed on the port side of each vessel to collect information about surface sediment material. Sidescan sonar was acquired and recorded using SonarPro software in an Extended Triton Format (XTF). Differential GPS position from OmniSTAR was recorded by the Octopus F190 Precision Attitude and Positioning System and output in the World Geodetic System of 1984 (WGS84). The towfish altitude varied during the cruise because of shallowwater surveying operations. The XTF files collected were converted into CARIS data format for processing using Sonar Information Processing System (SIPS) to edit and create sidescan mosaics. All horizontal positions were offset relative to the position of the Octopus F190 precision attitude and positioning system antennae.

\section{Chirp Seismic-Reflection Profiles}

The seismic source employed in Study Area 3 consisted of an EdgeTech SB-424 towfish running EdgeTech's DISCOVER version 3.5.0 acquisition software and towed about $3 \mathrm{~m}$ behind the GPS antenna. The 8-m Glacier Bay catamaran was used as a platform. The data were acquired using a 4- to $16-\mathrm{kHz}$ frequency sweep, $43-\mathrm{kHz}$ sample frequency, and approximately $100-\mathrm{ms}$ record length. The source utilized in Study Area 2 and elsewhere consisted of an EdgeTech SB-512i towfish also running DISCOVER version 3.5.0 acquisition software, which was towed about $18 \mathrm{~m}$ behind the GPS antenna on the R/V Tommy Munro and $6 \mathrm{~m}$ on the S/V Irvington. The data were acquired using a $0.5-$ to $8-\mathrm{kHz}$ frequency sweep, 43-kHz sample frequency, and approximately 75-ms record length. The trace data are in standard SEG Y, revision 1, standard format. The gained SEG Y data were imported into OpendTect software for interpretation and volume estimates.

\section{Results}

\section{Physical Setting, Study Area 1 (Offshore Ship Island)}

The seafloor off the western part of the Mississippi barrier islands is smooth with a gentle south to southeastward slope (fig. 5). Water depths range from 4-14 m, with the shallowest depths along the western and northwestern edges of Study Area 1, offshore of Cat Island and between Cat and Ship Islands. The deepest water depths are along the southeastern edge of this Study Area, south of the western end of Horn Island. A second shoal area that is identified on navigation charts and labeled Loggerhead Shoal occurs south of Camille Cut. A large part of Loggerhead Shoal is less than $6 \mathrm{~m}$ deep. With the exception of anthropogenic features (for example, dredged channels and dredge spoil deposits), most of the seafloor has gradients between 0.0001 and 0.2 degrees $\left(^{\circ}\right)$. Only along the front of the ebb-tidal delta at Dog Keys Pass do seafloor gradients locally exceed $2^{\circ}$. 


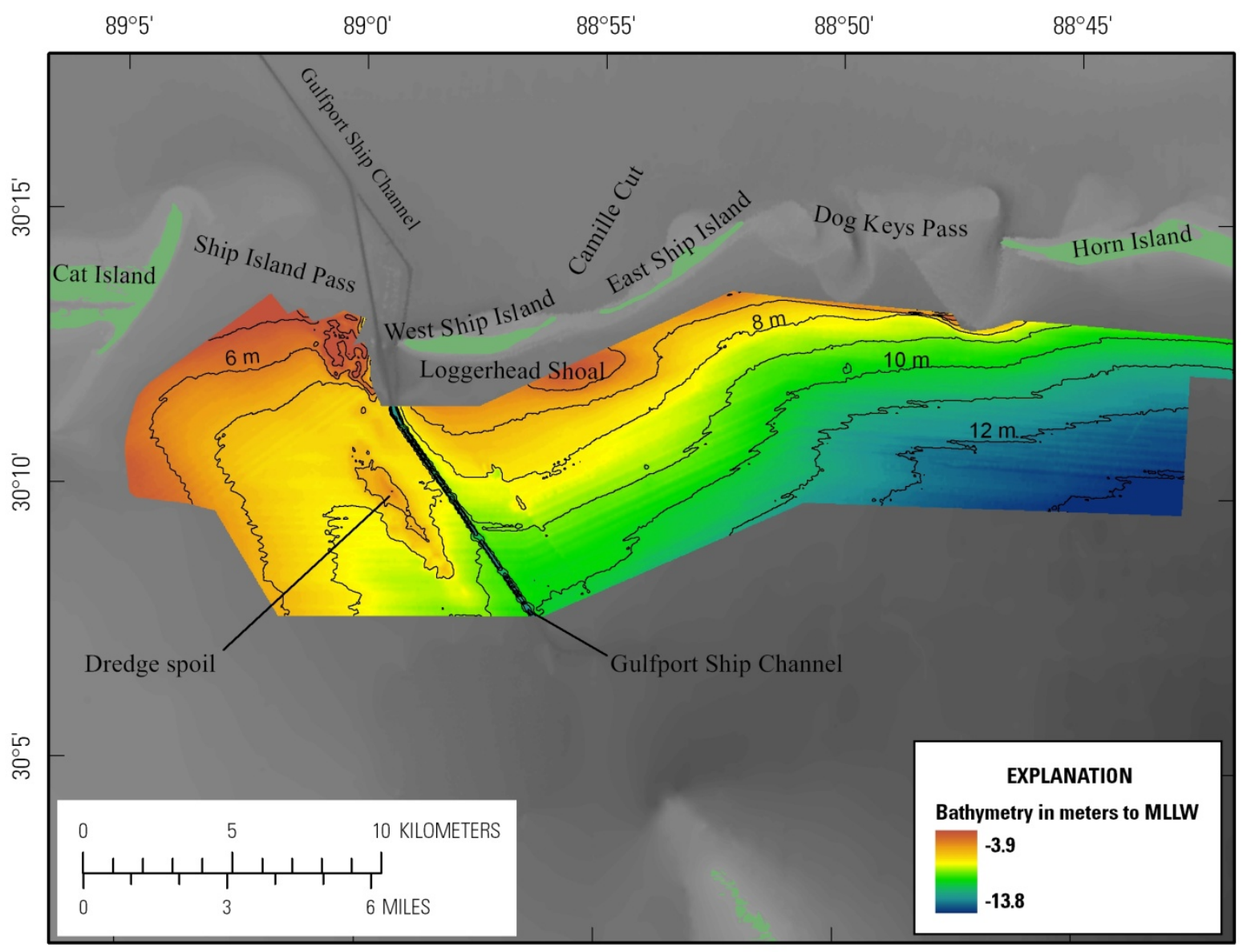

Figure 5. Bathymetry of Study Area 1, with 1-meter $(\mathrm{m})$ contours overlain. Depths relative to mean lower low water (MLLW).

Features that have the greatest local relief and some of the steepest slopes are manmade. These include the Gulfport Ship Channel and dredge spoil deposits. The Gulfport Ship Channel is cut $4 \mathrm{~m}$ into the seafloor at the northern edge of Study Area 1, its relief decreases to $2.5 \mathrm{~m}$ at the southern edge, and the slopes of its walls mostly exceed $1^{\circ}$. Dredge spoil deposits occur on both sides of the channel, but the deposit east of the channel has less than $0.4 \mathrm{~m}$ relief, while deposits to the west stand as much as 2 $\mathrm{m}$ above the surrounding seafloor. The southern dredge spoil area west of the channel has relief less than $1.4 \mathrm{~m}$ and slopes that do not exceed $0.2^{\circ}$. The northern dredge spoil area has as much as $2 \mathrm{~m}$ relief and slopes that approach $1^{\circ}$.

Sidescan-sonar imagery was used to identify five distinct seafloor types within Study Area 1 (figs. 6 and 7). The definition of the seafloor types was based mainly on variations in intensity and granularity of the acoustic backscatter. Previously collected surface sediment samples (Williams and others, 2007) and the bathymetry aided in the interpretation of the sidescan-sonar imagery (fig. 7). Two of the identified facies (Gulfport Ship Channel and dredge spoil) are of anthropogenic origin, and the other three (collapse feature and high and low backscatter) have resulted from natural processes. 


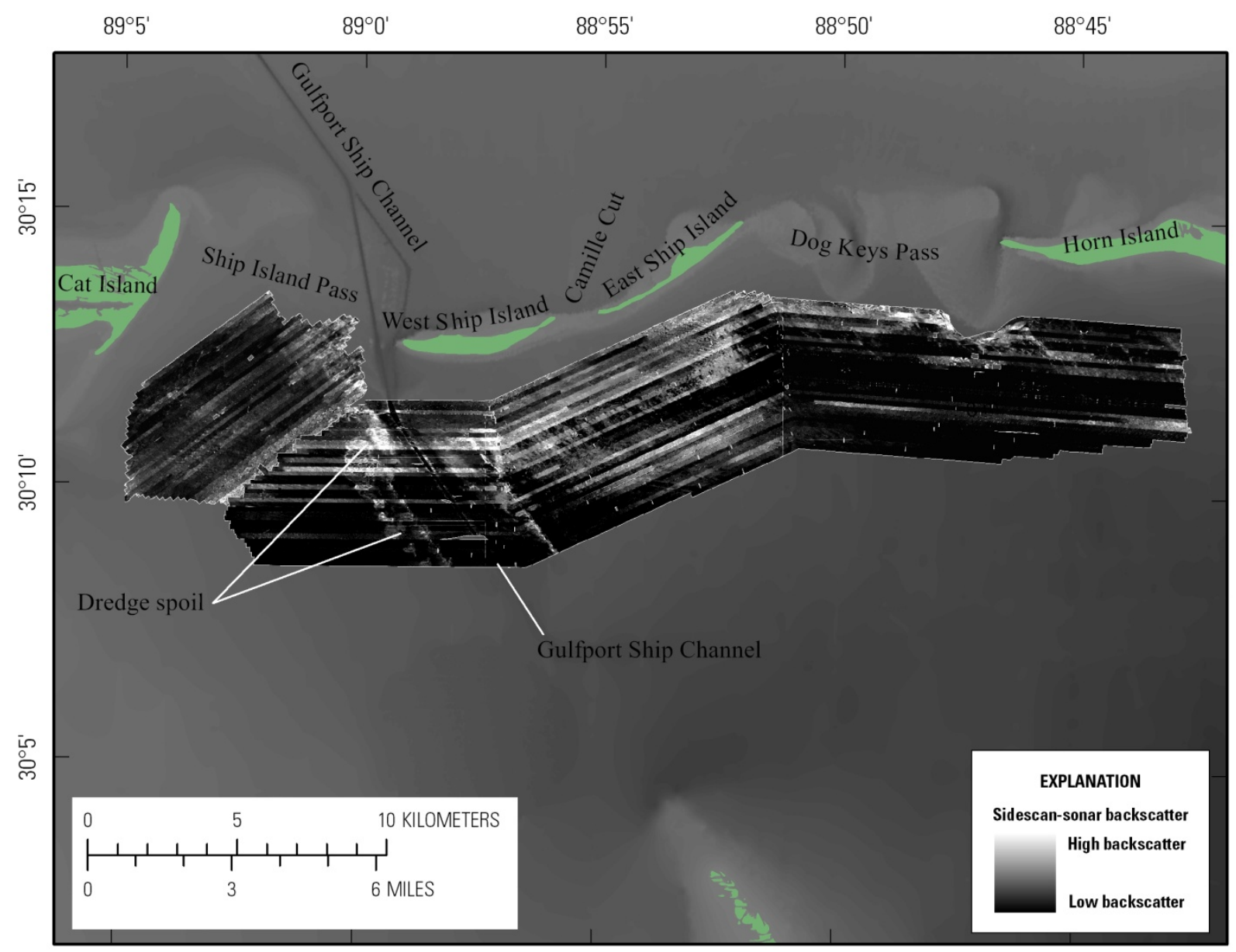

Figure 6. Sidescan sonar image of Study Area 1. Areas of high backscatter are shown as light tones and areas of low backscatter as dark tones. 


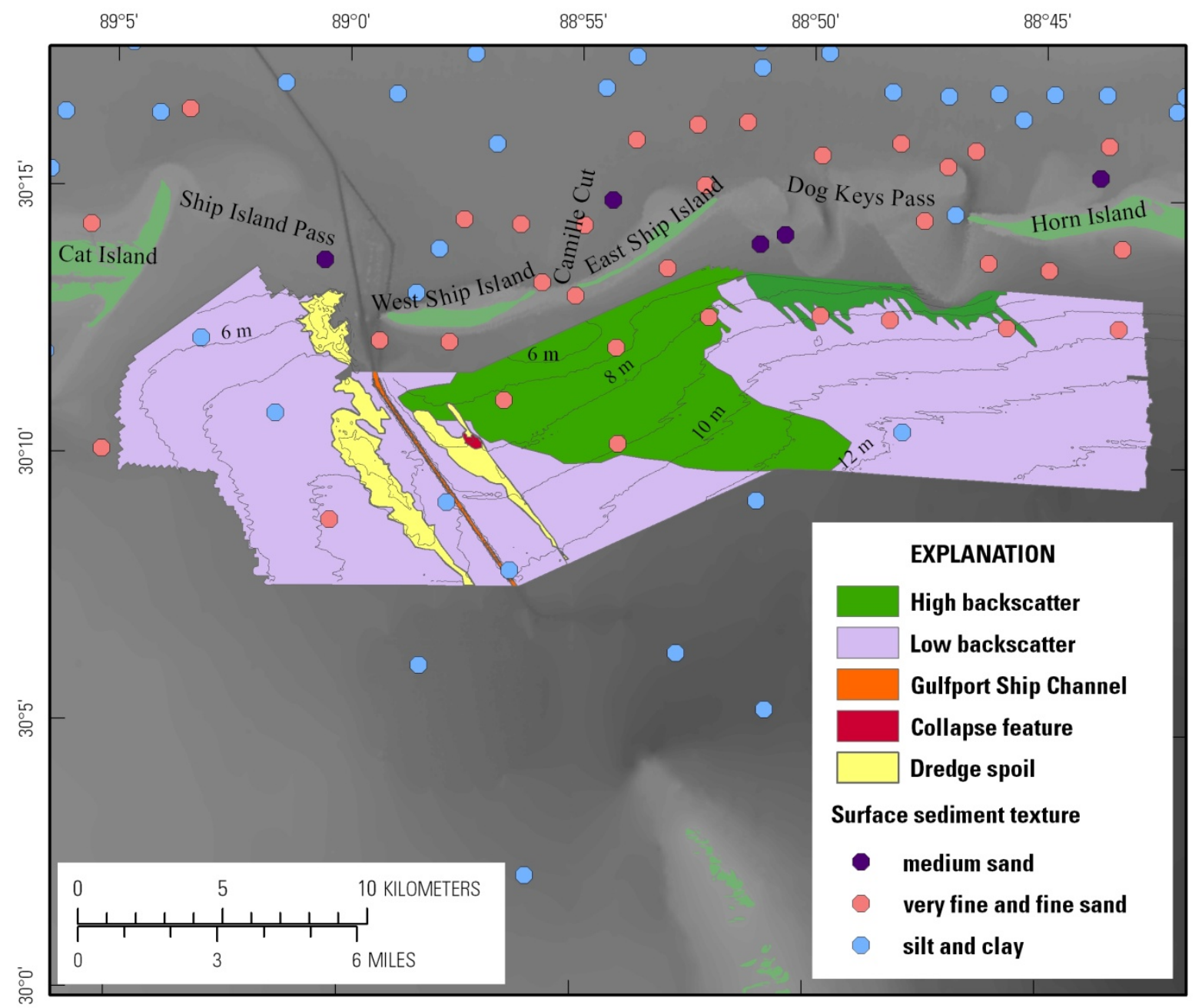

Figure 7. Interpretive map of Study Area 1 showing areas of varying backscatter intensity based on the sidescansonar imagery, and grain size of surface sediment samples from the USGS uSSEABED database overlain (Williams and others, 2007).

A large area with a high backscatter signature extends approximately $12 \mathrm{~km}$ along the shoreward edge of the survey area off East and West Ship Islands and as much as $8 \mathrm{~km}$ offshore of East Ship Island (figs. 6 and 7). Samples collected from this area show that the surface sediments have a mean grain size of very fine to fine sand (fig. 7), and the highest sand content and coarsest sand are in samples nearest to shore (Williams and others, 2007). A second high-backscatter area lies along the northeastern edge of the survey area immediately offshore of Dog Keys Pass (figs. 6 and 7). This high-backscatter area coincides with and extends slightly offshore of the steep seaward limit of the Dog Keys Pass ebb tidal delta. The few surface samples collected in this area indicate that the high-backscatter area is also composed of very fine to fine sand (fig. 7).

Uniform low backscatter zones dominate much of Study Area 1 west of the Gulfport Ship Channel and east of the ship channel seaward of the high-backscatter areas off the Ship Islands and Dog Keys Pass (fig. 6). Surface sediment samples from the low-backscatter areas recovered silt and clay for the most part (fig. 7). 
A small depression interpreted as a shallow collapse feature is located east of the Gulfport Ship Channel about $4 \mathrm{~km}$ south of West Ship Island (figs. 5, 7, and 8). The feature is approximately $400 \mathrm{~m}$ wide and $800 \mathrm{~m}$ long, and bathymetry shows that its steep edges lead to a shallow floor about $1 \mathrm{~m}$ below the surrounding seafloor. The edge of the feature produces a high-backscatter rim, while its predominantly low-backscatter floor is interrupted by discrete high-backscatter targets (fig. 8). The feature looks similar to other collapse features mapped on the inner shelf of the Mississippi Delta (Coleman, 1988; Twichell and others, 2009).

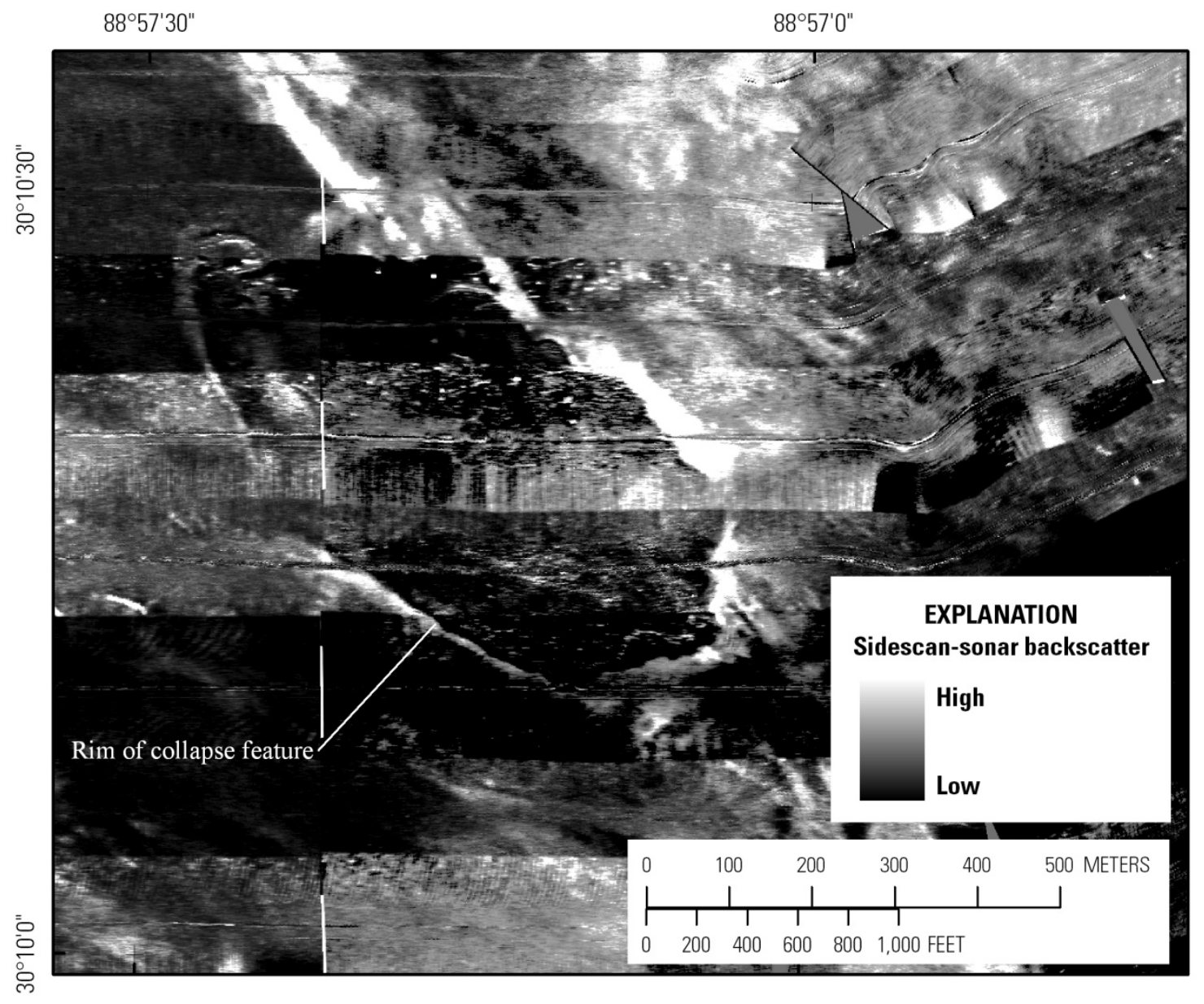

Figure 8. Collapse feature adjacent to dredge spoil mounds on the eastern side of the Gulfport Ship Channel. Location of the collapse feature is shown on figure 7.

Two manmade features imaged in the sidescan-sonar imagery are the Gulfport Ship Channel and the dredge spoil deposits that flank it on either side (figs. 6 and 7). The channel extends southeastward from the western tip of West Ship Island across the survey area. The sidescan imagery shows that its walls produce moderate backscatter, while the very low backscatter of the channel floor suggests that it is covered by mud (fig. 6). The dredge spoil deposits produce irregular moderate- to high-backscatter areas to either side of the ship channel. The deposits east of the ship channel are smaller and of lower relief than those to the west. 
A reconstruction of Holocene stratigraphy has been interpreted from the dense grid of seismic profiles collected in Study Area 1 (fig. 2). Gas in the sediment prevented imaging of the deeper stratigraphy for much of the area south of West Ship and Cat Islands (fig. 4), so the stratigraphic descriptions in this zone are limited to the shallow portions of the profiles that were not obscured by the gas. Consequently, our understanding of the early Holocene stratigraphy is limited to approximately the eastern two-thirds of Study Area 1.

The deepest horizon mapped is an erosional surface that is interpreted to have formed during the last lowstand of sea level during the Quaternary. This surface could be mapped completely only in the eastern part of Study Area 1, where it was not masked by gas (fig. 9). The surface dips gently to the south, increasing from $13 \mathrm{~m}$ below sea level along the shoreward edge of the survey area to $17-19 \mathrm{~m}$ along the offshore edge of the survey area. It is incised by several valleys with thalweg depths as deep as $29 \mathrm{~m}$ below sea level. It is likely that additional channels incise this surface south of West Ship Island and between West Ship and Cat Islands, but gas interfered with imaging of the deeper subsurface in each of these areas. 


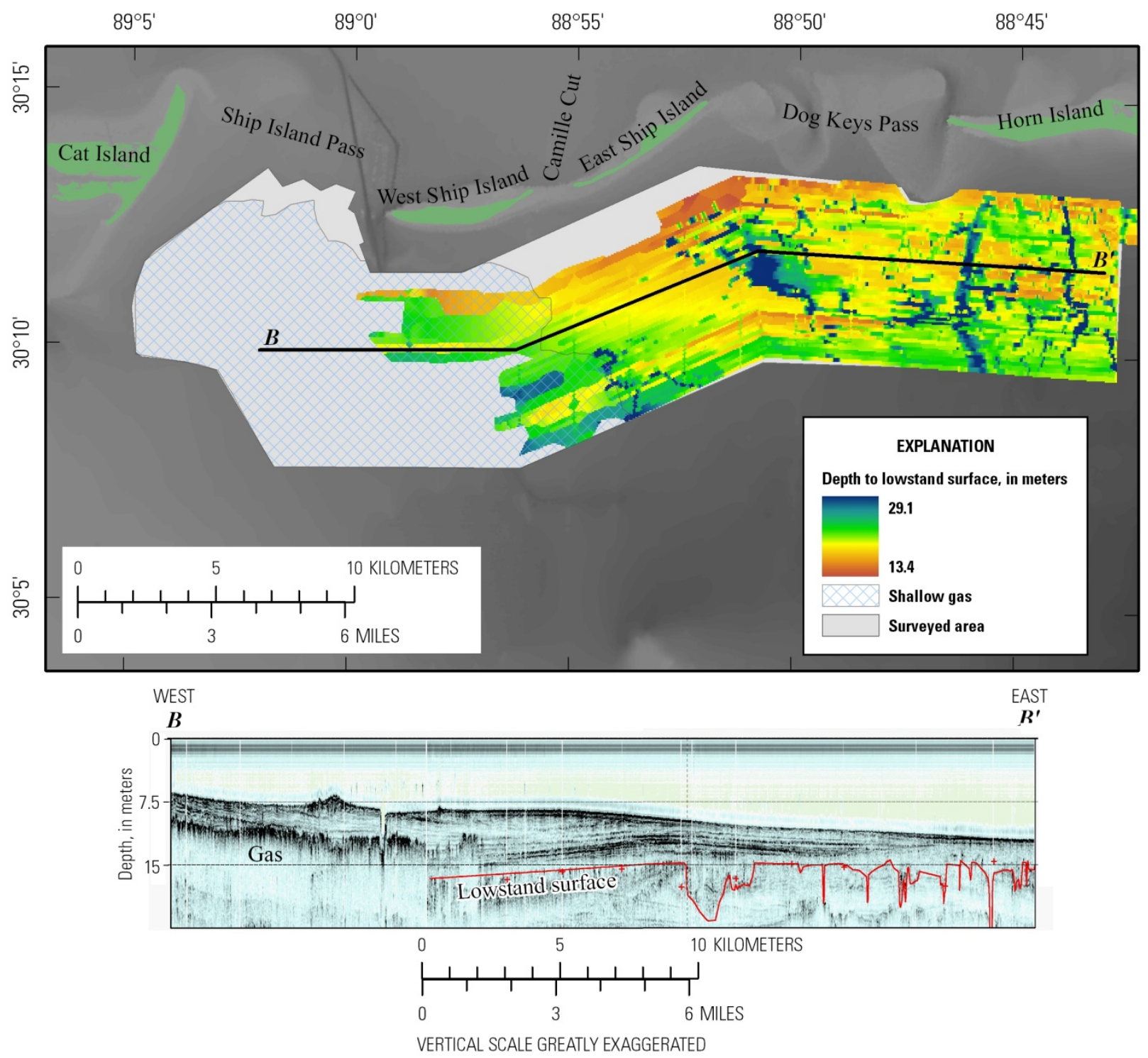

Figure 9. Map of Study Area 1 showing the depth to the lowstand surface that was formed during the latest Pleistocene. The lowstand surface is highlighted in red on the seismic profile. Zero (0) on the vertical scale of the seismic profile is relative to the sea surface.

Holocene sediment thickness above this erosional unconformity is shown in figure 10. The thickest accumulations, up to $20 \mathrm{~m}$, fill lowstand valleys. Aside from the valley fills, Holocene sediments generally thicken to the west from 3-5 m near the eastern edge of Study Area 1 to 8-10 m south of West Ship Island. It is unclear how sediment thickness trends westward of central West Ship Island, where the profiles are obscured due to gas blanking.

The Holocene sedimentary section is characterized by six seismic units (fig. 11). The units were defined based on seismic character, spatial geometry, sedimentary facies observed in cores, and the sidescan-sonar backscatter produced by units exposed at the seafloor. 


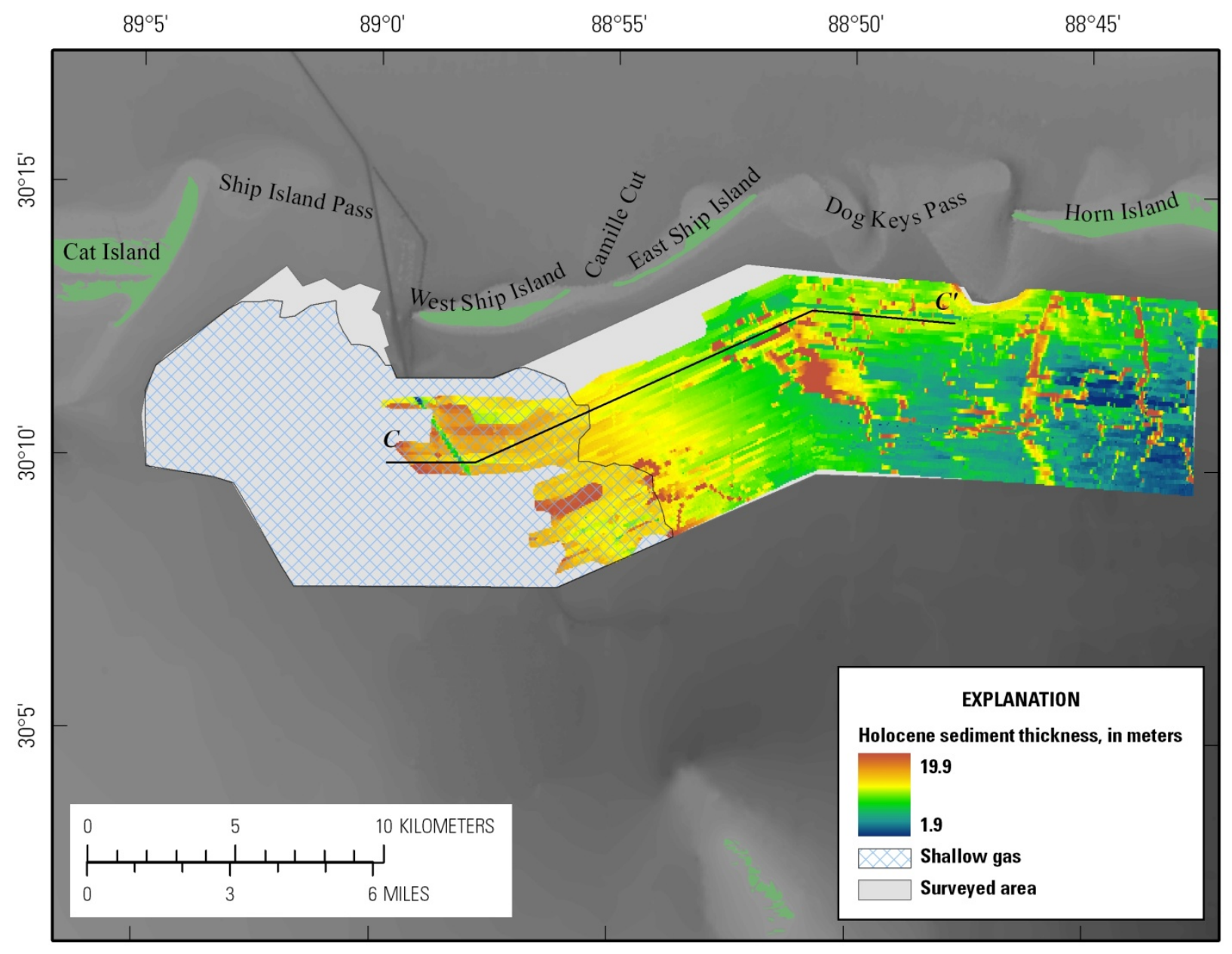

Figure 10. Map of Study Area 1 showing the total thickness of Holocene sediment. Excluding the fluvial valleys, where the Holocene sediment is thickest (eastern region), there is a general increase in Holocene sediment thickness toward the west. Profile C-C' is shown in figure 11. 


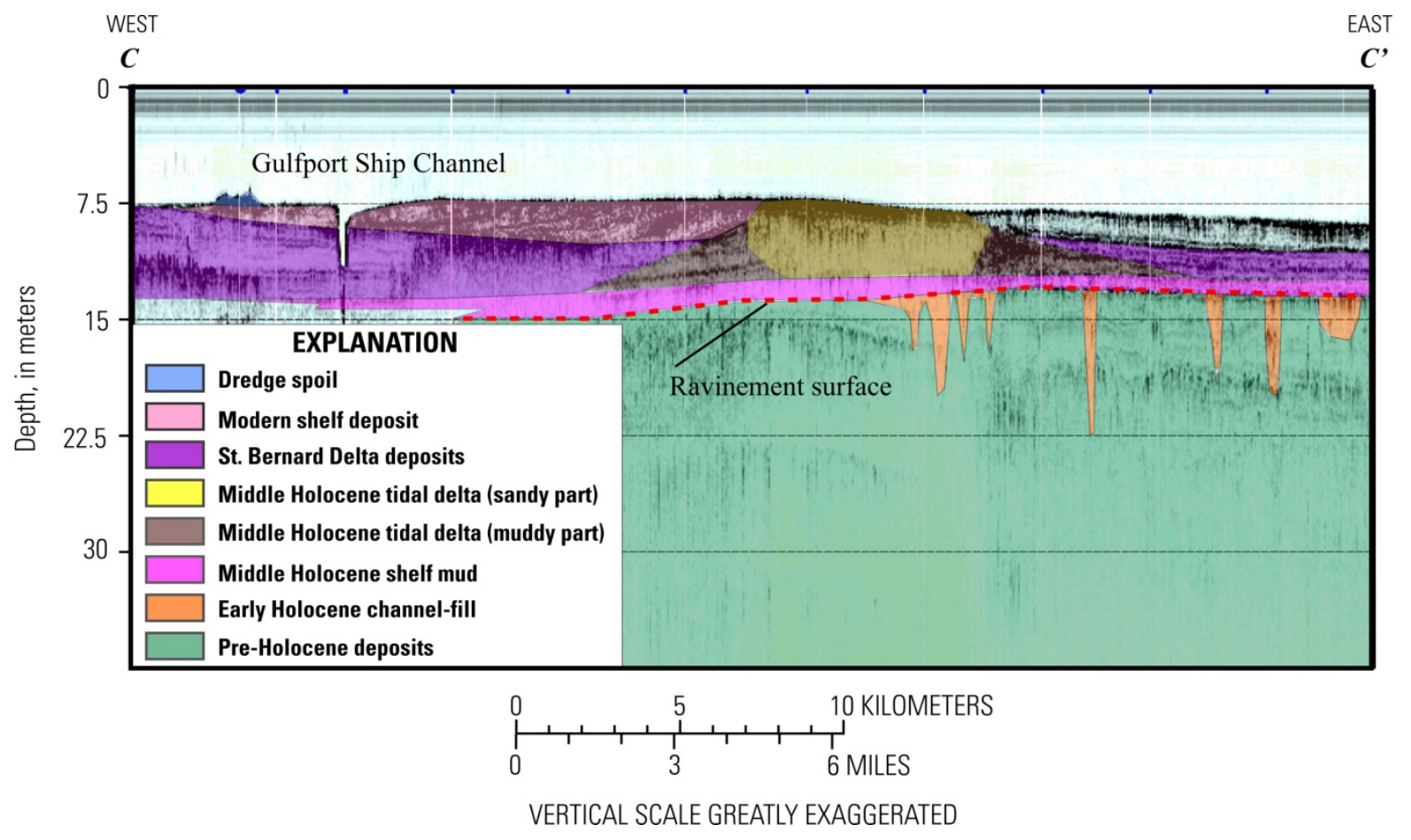

Figure 11. Chirp profile showing the six units that compose the Holocene sedimentary section in Study Area 1 plus pre-Holocene deposits. Profile location shown on figure 10. Zero (0) on the vertical scale of the seismic profile is relative to the sea surface. Chirp data from Pendleton and others (2011).

The oldest Holocene unit fills the valleys in the lowstand unconformity. These fluvial valleys were incised during the last lowstand of sea level and display both sinuous and dendritic patterns in map view (fig. 12). The valley-fill sediments compose gently to steeply dipping foreset beds that are commonly interrupted by cut-and-fill structures (fig. 12, profile). Cores recovered sand and muddy sand from the valley-fill interval, and visual descriptions indicate that the sand is mostly fine to medium grained. This unit is capped by a ravinement surface, an unconformity that formed while the shoreline transgressed across the shelf during the Holocene sea-level rise (fig. 11). 


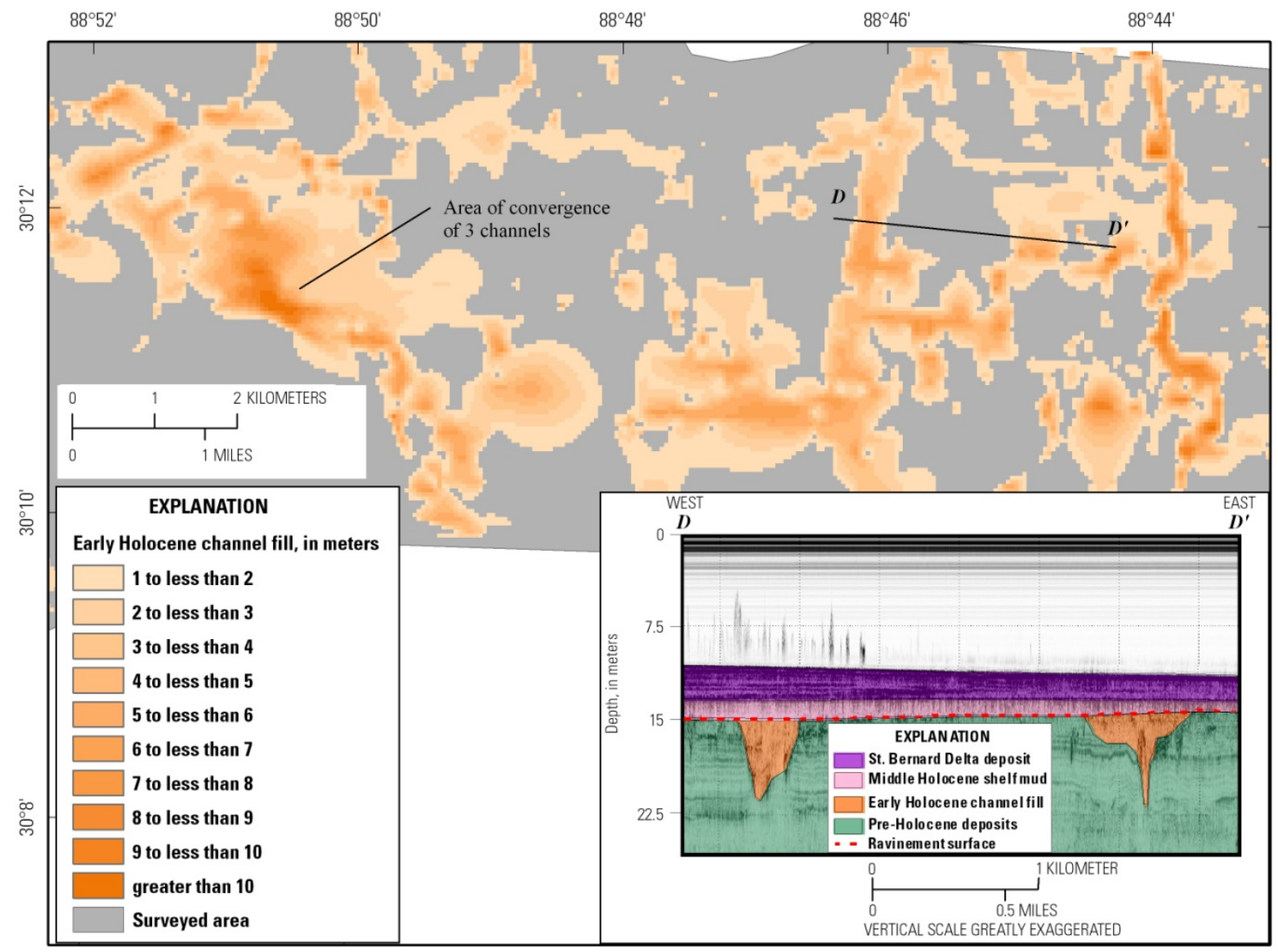

Figure 12. Map showing the distribution and thickness of sediment contained in the valleys in Study Area 1 that were cut during the last lowstand of sea level. The seismic profile shows that these early Holocene valley-fill deposits are buried by a thick cover of muddy sediment. Zero (0) on the vertical scale of the seismic profile is relative to the sea surface. Chirp profile from Pendleton and others (2011).

The second unit, which rests on the ravinement surface throughout much of Study Area 1, is a thin (1-3 m), acoustically transparent deposit (fig. 11) that vibracores show to be composed of muddy sediment. This interval is interpreted to be equivalent to an interval described by Otvos (1981) in cores from the Mississippi barrier islands that consisted of muddy shelf deposits resting directly on the ravinement surface.

The third unit is an acoustically massive deposit that is divided into two parts: the east-west trending Ship Island Pass shoal and Ship Island shoal and tidal delta (figs. 13 and 14). The Ship Island Pass shoal rests directly on the ravinement surface (fig. 13A). The deposit extends beyond the survey area, and its description is based on observations from two locations that lay within the Study Area 1. The seaward edge of the Ship Island Pass shoal is less than $4.5 \mathrm{~m}$ thick, and its southern edge pinches out abruptly along a trend that connects West Ship Island with the central part of Cat Island (fig. 14). The feature was mapped for over $5 \mathrm{~km}$, and cores indicate that it is composed of fine sand. 

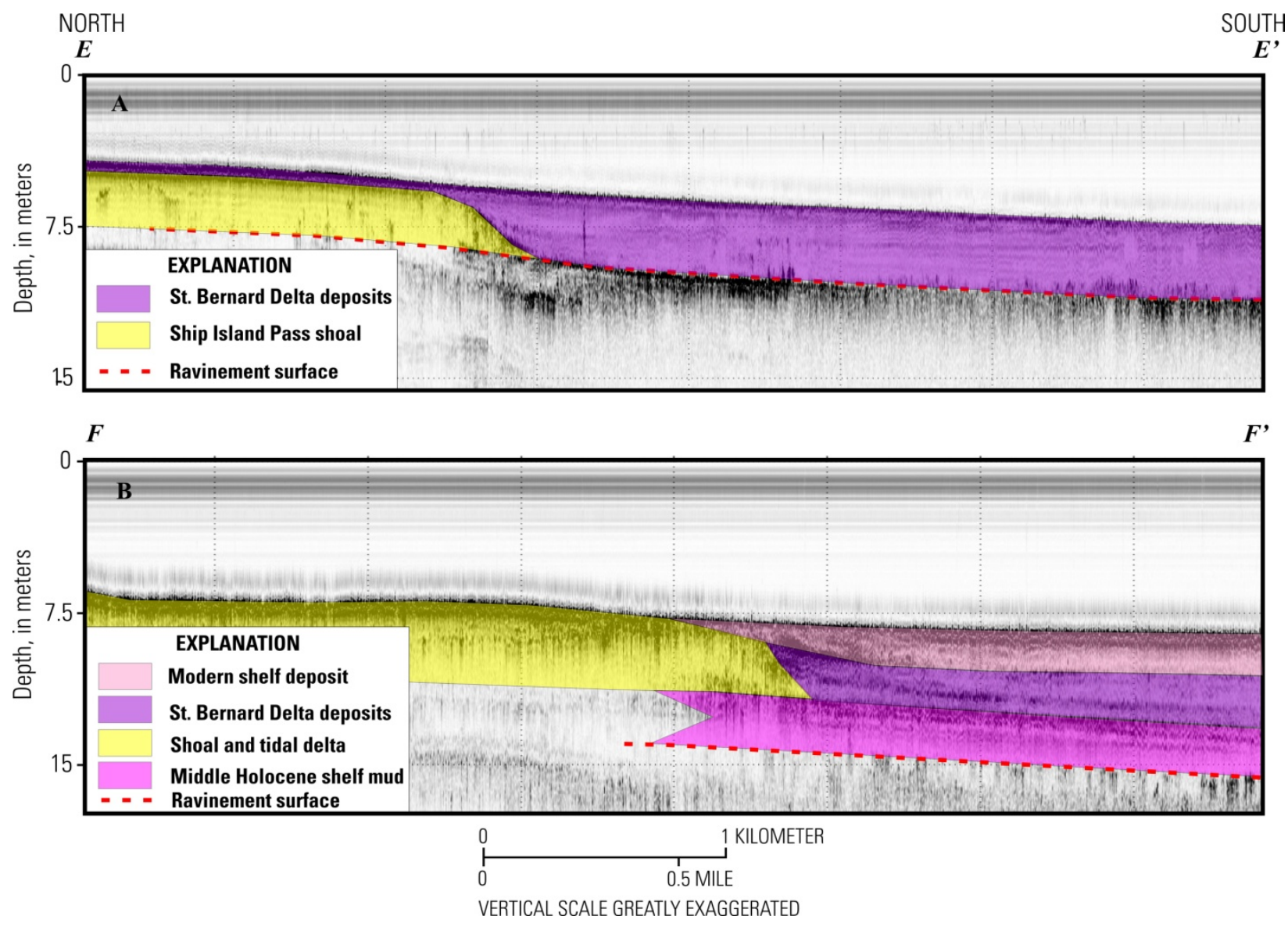

Figure 13. Two north-south trending Chirp profiles across the buried shoal in Ship Island Pass (A) and the exposed tidal delta off East Ship Island (B). Profile locations are shown in figure 14. Zero (0) on the vertical scale of the seismic profiles is relative to the sea surface. Chirp data from Pendleton and others (2011). 


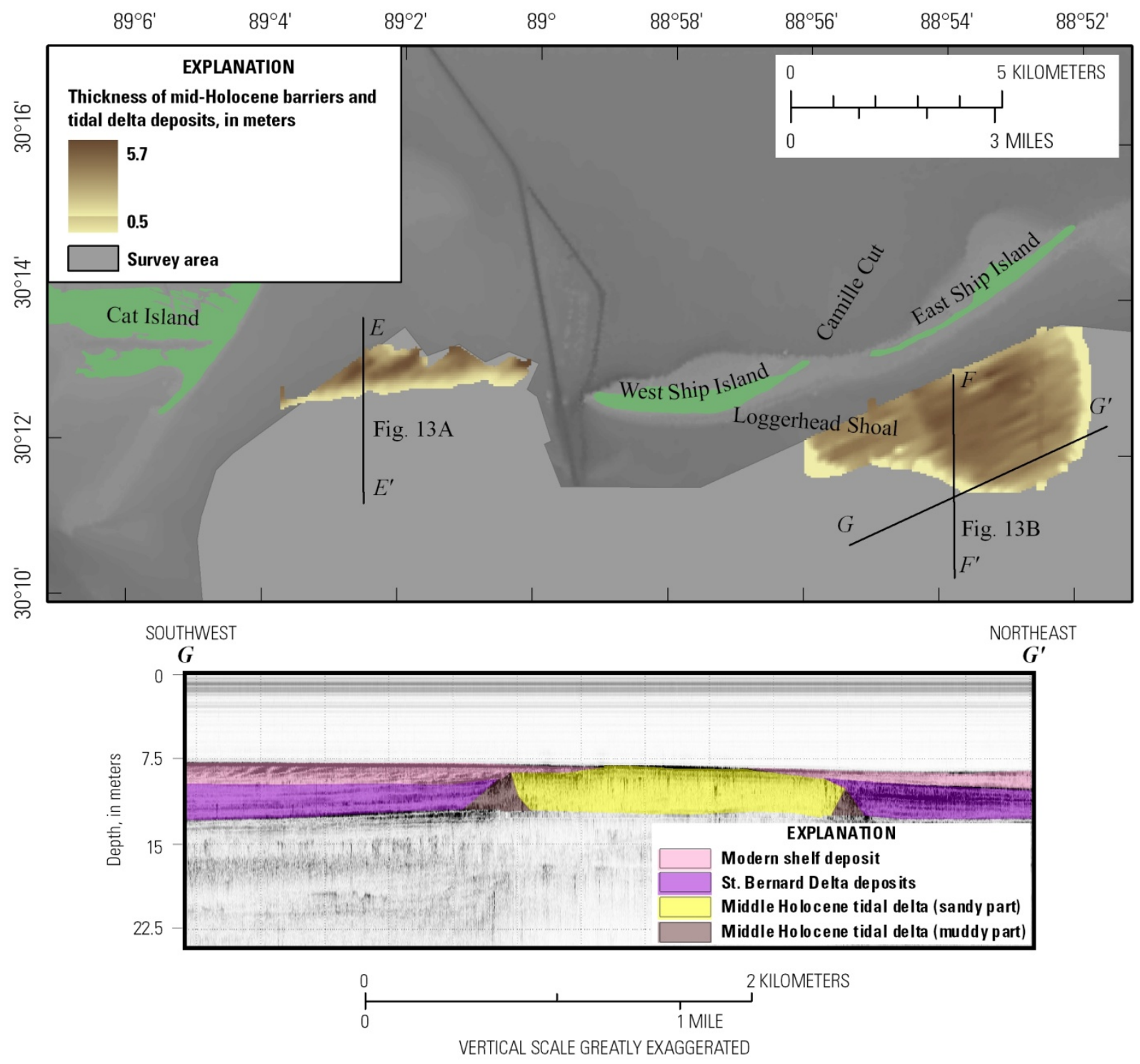

Figure 14. Map showing the location and thickness of the southern part of the Ship Island Shoal deposit and the tidal delta deposit off East Ship Island. Zero (0) on the vertical scale of the seismic profile is relative to the sea surface.

The second part of this acoustically massive unit lies south of East Ship Island and Camille Cut. This part of the deposit is semicircular with a narrow westward extension along the northern edge of the survey area (fig. 14). The semicircular part is approximately $4.5 \mathrm{~km}$ in diameter, and the narrow extension trends an additional $2.5 \mathrm{~km}$ to the west. The maximum thickness of the deposit is approximately $5.5 \mathrm{~m}$. In cross section, the semicircular part has a flat base and a mounded top (figs. 13B and 14, profile). The acoustically massive central portion is fringed on either side by narrow intervals of closely spaced subparallel reflectors that dip gently away from it. Cores show that the acoustically massive central portion consists of medium to fine sand with scattered shell fragments, 
while the fringing areas are composed of mud. The massive unit, where it is exposed on the seafloor, produces high backscatter in sidescan-sonar imagery (fig. 6). The westward extension is also acoustically massive and corresponds with the location of Loggerhead Shoal (fig. 5). This part of the deposit stands 1-1.5 m above the surrounding seafloor (fig. 5), and cores indicate that it is composed of medium to fine sand.

The fourth seismic unit, the St. Bernard Delta deposit, is characterized by acoustic laminations (fig. 15A) and covers the entire southern part of Study Area 1 (fig. 16). This unit onlaps and partially or completely buries the acoustically massive units in Ship Island Pass (fig. 13A) and south of East Ship Island (fig. 13B). Seismic profiles show that this unit is $1-2 \mathrm{~m}$ thick in the southeastern part of the area and increases to more than $6 \mathrm{~m}$ thick to the west (fig. 11). The maximum thickness of this deposit is unknown because gas masks the base of the deposit throughout much of its extent in the western part of Study Area 1. Cores show that this unit is composed of clay or silty clay.
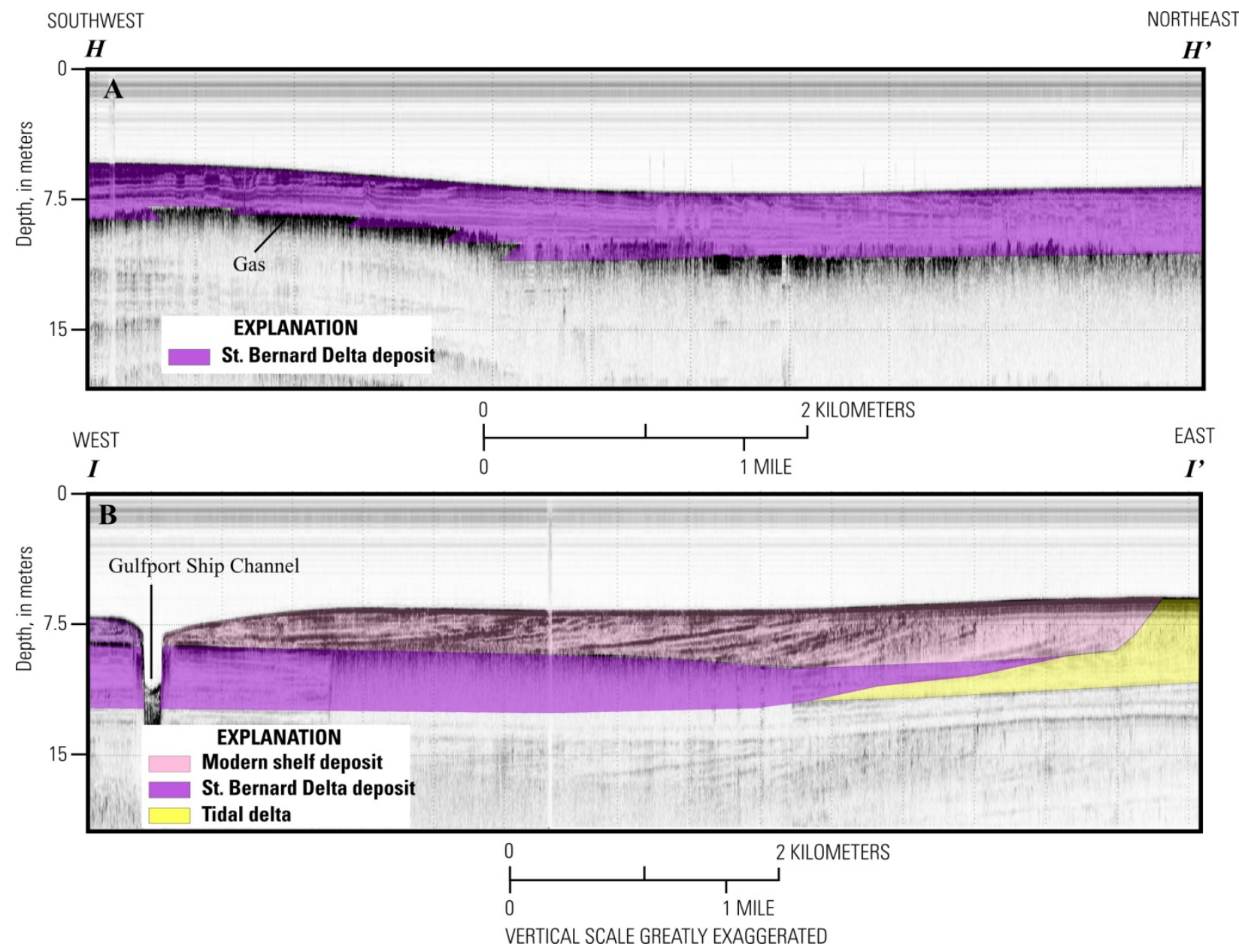

Figure 15. Seismic profiles showing $(A)$ the acoustically finely laminated nature of the St. Bernard Delta deposits, with the base of these deposits commonly being masked by gas, and $(B)$ the modern shelf deposit off West Ship Island that is characterized by the westward-dipping foreset beds. Zero (0) on the vertical scale of the seismic profiles is relative to the sea surface. Profile locations shown in figure 16. 


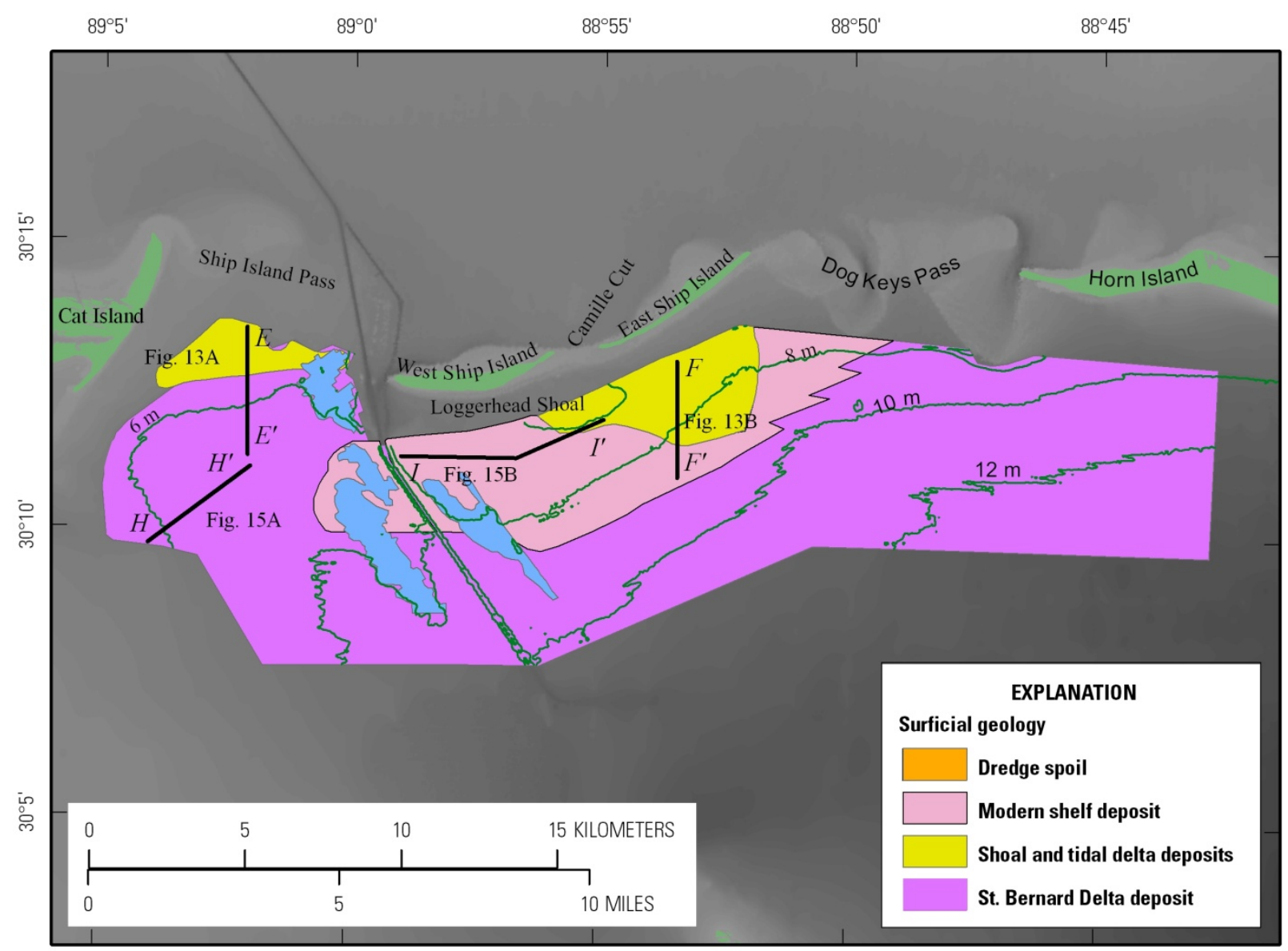

Figure 16. Map showing the distribution of the four Holocene units that are exposed on the seafloor within Study Area 1. The eastern edge of the modern shelf deposit is drawn as a jagged line because its precise location could not be resolved with available data.

The fifth seismic unit, the modern shelf deposit, is characterized by parallel westward-dipping reflectors and covers a large part of the inner shelf, extending between East Ship Island and just west of the Gulfport Ship Channel (figs. 15B and 16). This deposit is up to $3 \mathrm{~m}$ thick south of West Ship Island and gradually thins offshore and to the west. To the east it thins more abruptly where it onlaps the underlying Ship Island shoal/tidal delta deposit south of East Ship Island (fig. 11). The top of the deposit is exposed at the seafloor except in areas where it is covered by dredge spoil on either side of the Gulfport Ship Channel (fig. 16). Cores indicate that the deposit is primarily composed of silty clay, which produces mostly high backscatter in the sidescan imagery (fig. 6).

The sixth, and youngest, unit has an acoustically chaotic signature and is identified as dredge spoil on either side of the Gulfport Ship Channel (figs. 16 and 17). These deposits are thicker nearshore and thinner offshore, and the thickest and most extensive accumulations (up to $2.9 \mathrm{~m}$ ) lie along the west side of the ship channel. Cores indicate that the spoil deposits primarily consist of fine sand. They generally produce high backscatter in the sidescan-sonar imagery (figs. 6,7), and the linear trend of the dumpsite west of the ship channel is easily identified in the bathymetry (fig. 5). While the dredge spoil 
deposits east of the Gulfport Ship Channel are identifiable from high-backscatter signatures in the sidescan-sonar imagery, they are too thin to be resolved by the seismic profiles.

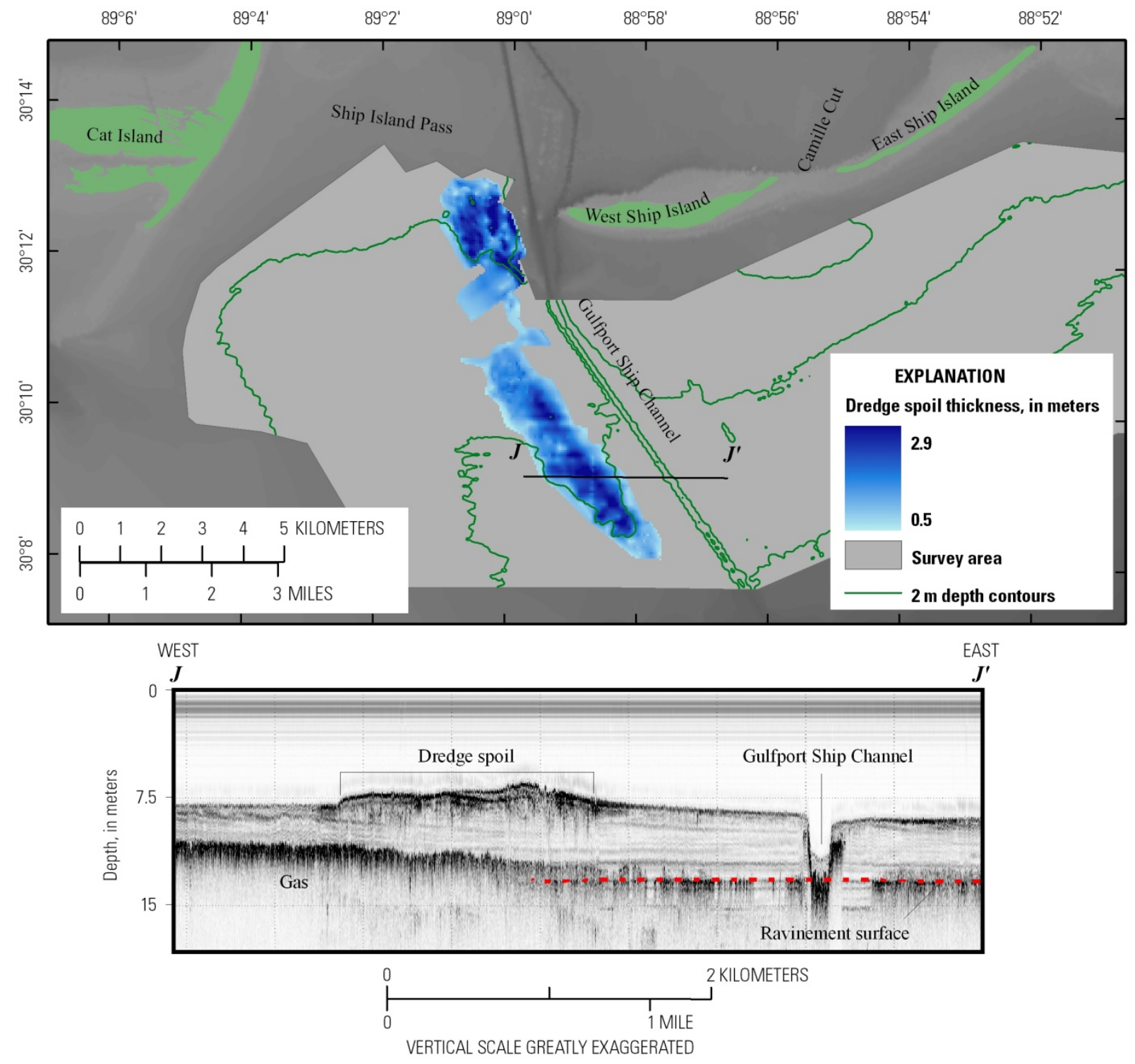

Figure 17. Map showing the distribution of dredge spoil that exceeds 0.5 meter in thickness and seismic profile showing the bathymetric expression and acoustic nature of the deposit. Zero (0) on the vertical scale of the seismic profile is relative to the sea surface.

Of the six Holocene units identified in the seismic profiles, the surfaces of four are exposed on the seafloor. Figure 16 illustrates the spatial distribution of these four units, as determined through integrated interpretation of the seismic, vibracore, and sidescan-sonar data. The early Holocene channel fill and middle Holocene shelf mud deposits are not exposed on the seafloor. 


\section{Physical Setting, Study Area 2 (Offshore Petit Bois Pass)}

The western half of Dauphin Island is an actively prograding spit less than $0.5 \mathrm{~km}$ wide, with an elevation of at most a few meters (Otvos and Carter, 2008). Between 1850 and 1960, westward growth exceeded $7 \mathrm{~km}$; however, since 1960, this rapid lateral accretion has been disrupted by breaching and overwash of the island from storms. Petit Bois Island originated as a narrow spit extending from Dauphin Island (Hardin and others, 1976). By the turn of the 19th century, Dauphin Island was breached and Petit Bois began migrating west as the eastern end eroded, widening Petit Bois Pass. From 1917 to 2005 the eastern $5 \mathrm{~km}$ were submerged and thus Petit Bois Pass was expanded. Rapid erosion has slowed as a vegetated beach-ridge complex on the eastern end of Petit Bois Island has acted to somewhat stabilize the remaining island and limit the expansion of the adjacent pass. The portions of the islands adjacent to Petit Bois Pass are characterized as beach and active overwash zones (Morton and Rogers, 2009). Beach sediment texture is 90-100 percent light-colored medium-grained sand. Petit Bois Pass is one of only two main passes within GUIS that does not have a deep channel that is maintained for shipping. During normal hydrodynamic conditions, currents from tidal exchange are the dominant processes affecting the morphology of the pass (McBride and others, 1991). However, tropical storms frequently rework the island flanks and the floor of this shallow pass.

Bathymetric surveys in Pfeiffer and others (2011) record water depths for the pass that average $3 \mathrm{~m}$, with 4-5-m-deep channels immediately adjacent to the island flanks (fig. 18, profile A). While the eastern channel remains offshore from Dauphin Island (McBride and others, 1991), a younger western channel and associated ebb delta continue to migrate with erosion of eastern Petit Bois Island. The seaward edge of the inlet platform has a $1^{\circ}$ slope between 3 and $8 \mathrm{~m}$ of water depth, which decreases to $<0.5^{\circ}$ with depth (fig. 18, profiles B and C). The Chirp profiles show that most of the inlet platform is 2.3-3.0 m thick, with some areas exceeding $4 \mathrm{~m}$. The estimated volume of sediment contained within this inlet platform is $46.9 \times 10^{6}$ cubic meters $\left(\mathrm{m}^{3}\right)$. For comparison, this amount equals 75 percent of the sediment sequestered within neighboring Petit Bois Island and its underlying platform. 

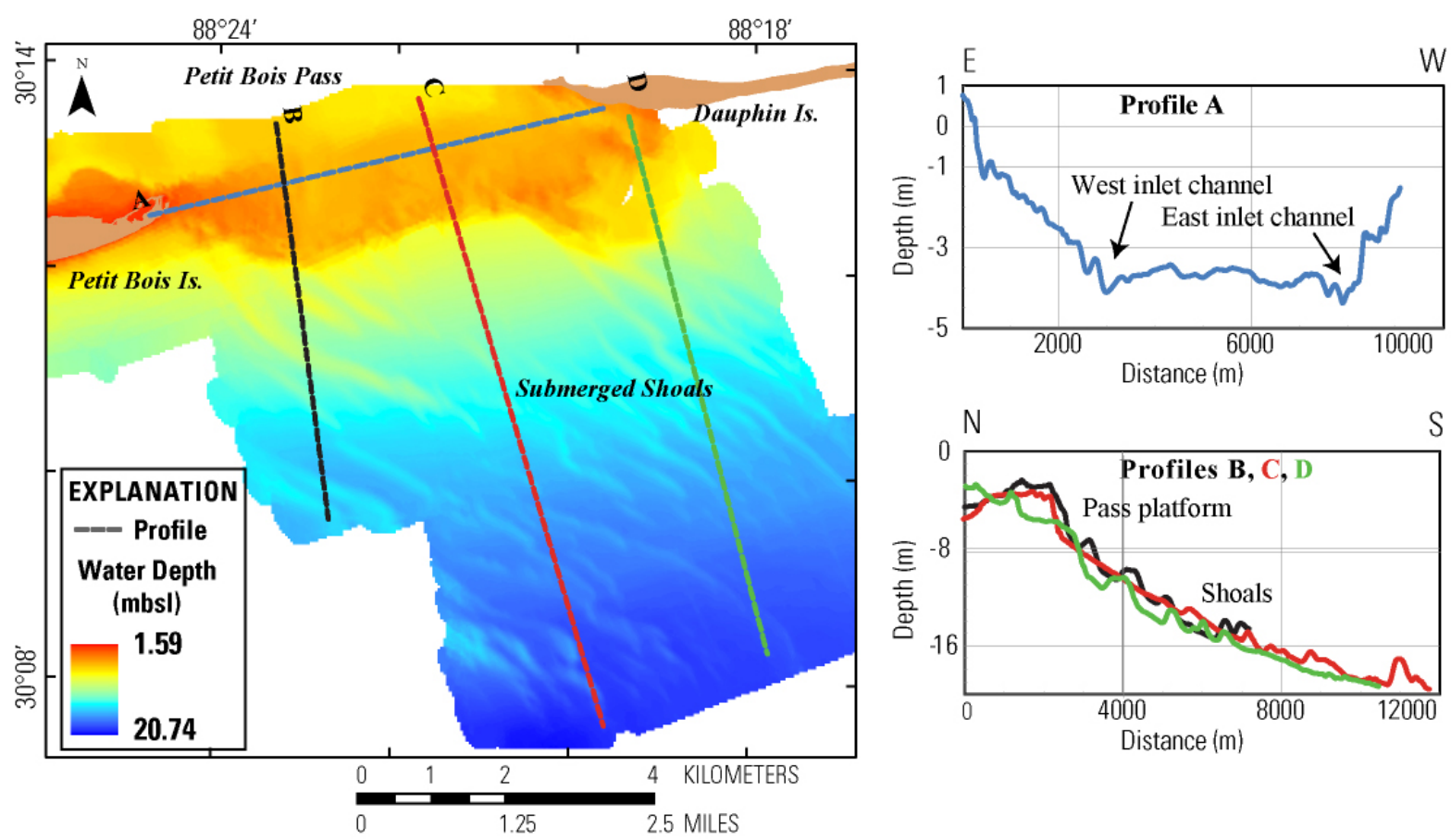

Figure 18. Bathymetry, in meters below sea level (mbsl), of Petit Bois Pass and offshore shoals (Study Area 2) with profiles of transects A-D. Data from Pfeiffer and others (2011).

The seafloor offshore of Petit Bois Pass contains a series of shoals (or ridges) that extend from the western tip of Dauphin Island to mid-Petit Bois Island and offshore beyond Study Area 2. The shoals trend northwest-southeast $\left(115-120^{\circ}\right)$, range in length from 1-3.5 km, and are 200-350 m wide. Shoal thickness, identified in Chirp profiles (fig. 19B), averages about $2 \mathrm{~m}$ but can exceed $5 \mathrm{~m}$. Estimated volumes of some of the shoals are shown in figure 19. The total volume of sediment contained in the shoals within Study Area 2 is approximately $56.6 \times 10^{6} \mathrm{~m}^{3}$, exceeding the volume contained within Petit Bois Pass, with most of this material sequestered in the large shoal field in the southwest corner of the area (fig. 19, area 3). 

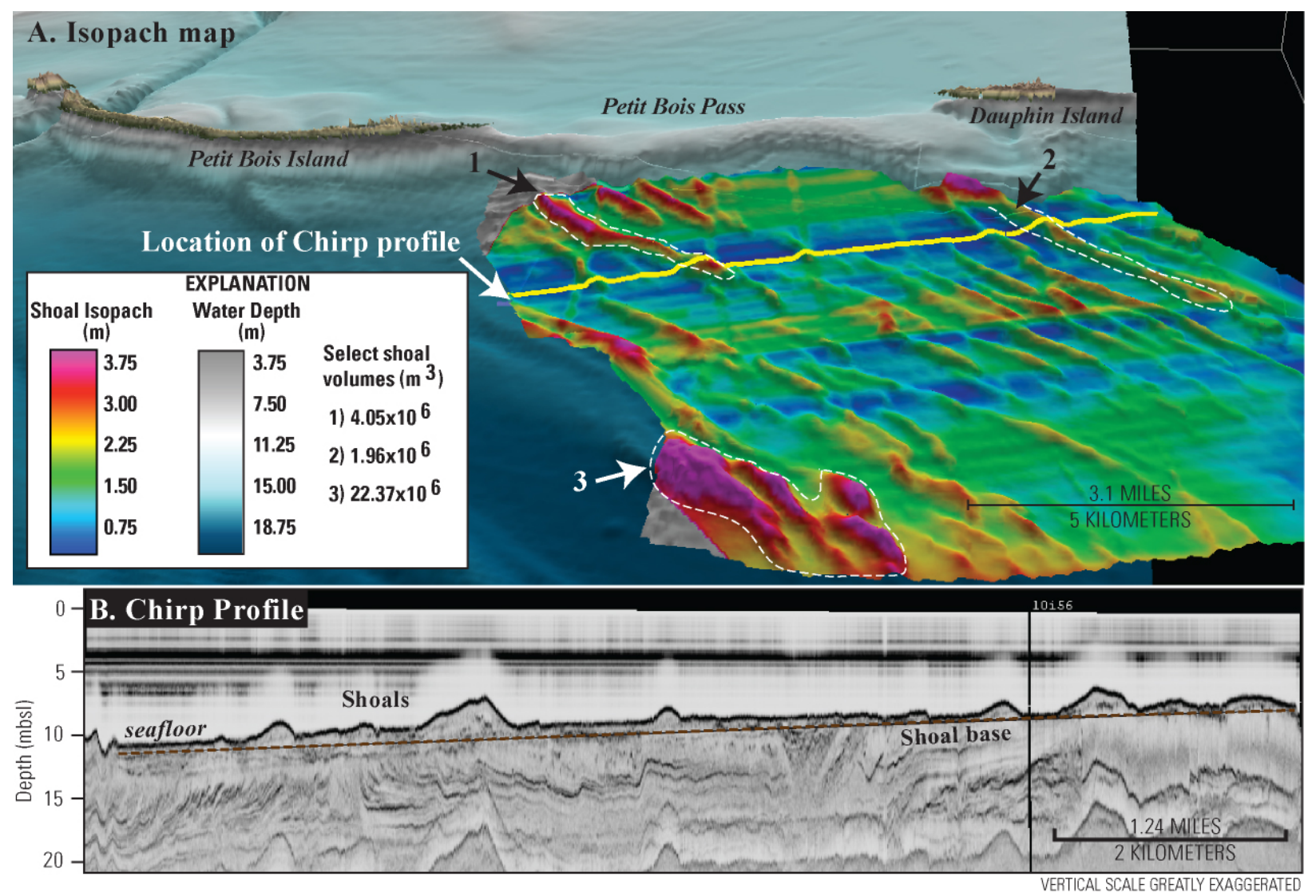

Figure 19. Isopach perspective (A) and example Chirp profile (B) of offshore shoals in Study Area 2. Island topography from 2007 Lidar elevation measurements; bathymetry from the National Geophysical Data Center (NGDC). White dotted lines and accompanying numbers indicate the extent of the shoals used for volume calculations. Zero (0) on the vertical scale of the seismic profile is relative to the sea surface.

The contrasting dynamics that shape Petit Bois Pass and the offshore shoals become apparent by comparing seafloor change over time. Figure 20 shows bathymetric Digital Elevation Models (DEMs) for three time periods between 1917 and 2010 (static arrows and lines between frames are used for reference). During the span of 90 years, the Dauphin Island spit has migrated westward over the east channel. As the inlet expanded westward, a small channel and associated ebb-tidal delta began forming to the west following submergence of the east end of Petit Bois Island. Although grid resolution is reduced in the earlier time period due to decreased data density, it is apparent that the shoals offshore have not migrated over time despite the rapidly changing shoreline and inlet, indicating that independent processes are driving shoal evolution. 

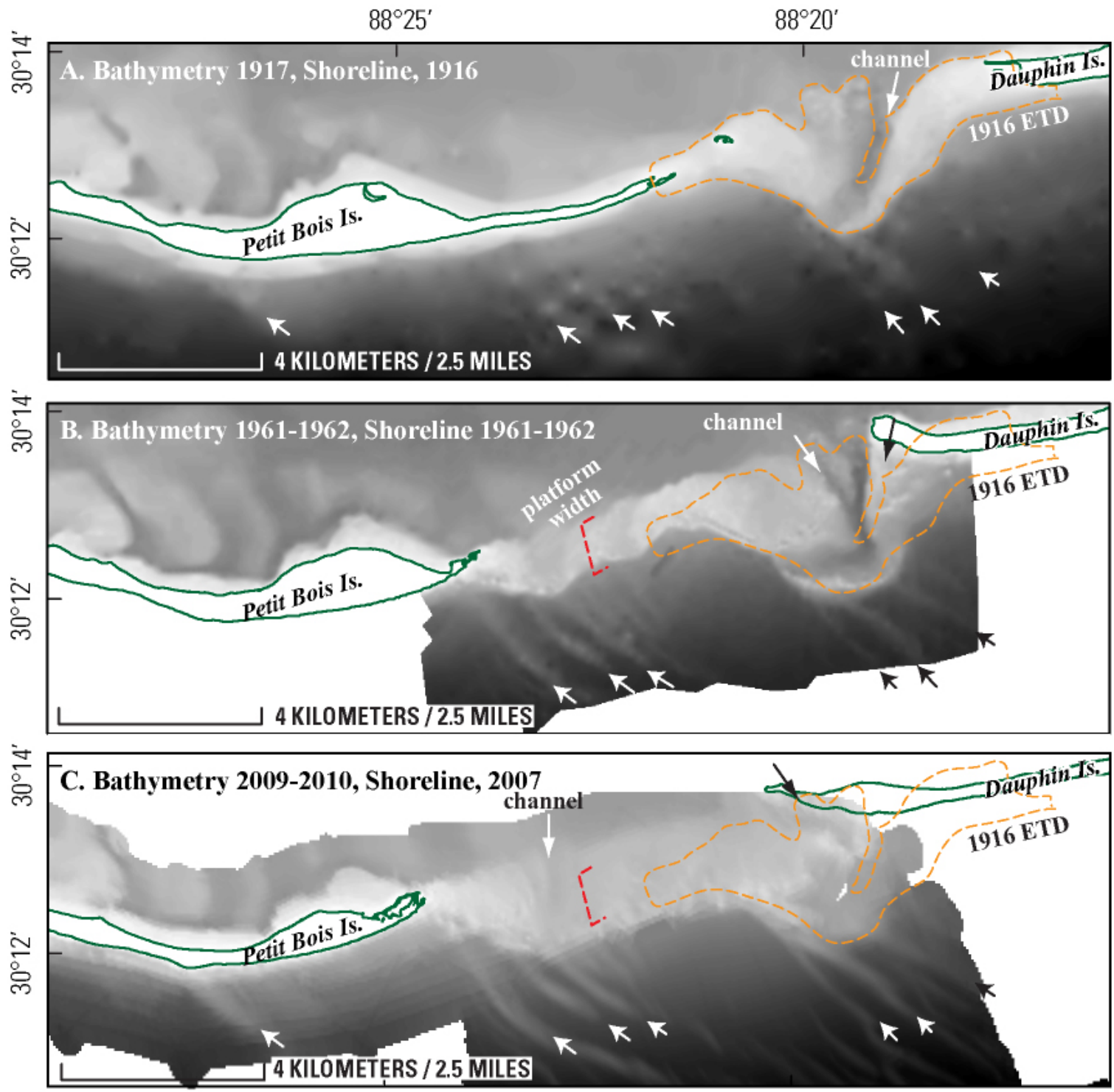

Figure 20. Bathymetric Digital Elevation Models (DEMs) for three time periods. Orange reference line of 1916 ebb-tidal delta (ETD) and location arrows of shoals are static. Historical dataset from Buster and Morton (2011); recent bathymetry data from Pfeiffer and others (2011).

Sidescan-sonar imagery (fig. 21A) depicts the shoals as long, thin areas of high backscatter, separated by wider and shorter areas of lower backscatter, which correspond to troughs in the bathymetry. The shoals taper at the ends and have jagged and variable reflectance along their flanks. Slope angles can be up to $1.4^{\circ}$ along the seaward tip (fig. 21B) and flatten out with decreasing water depth. There does not appear to be a steeper shoreward or seaward side. Elsewhere on the shelf, a steeper shoreward slope has been interpreted to be an indication of active migration (McBride and others, 1999). 


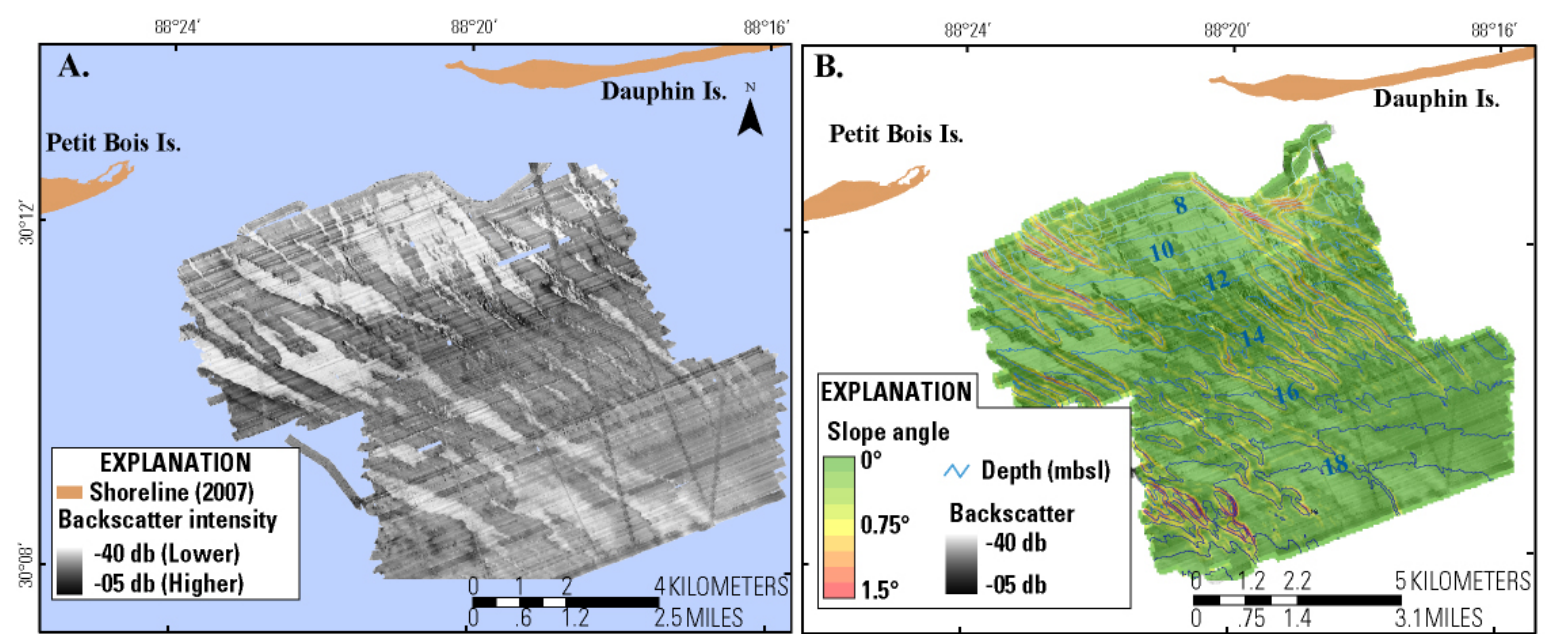

Figure 21. Sidescan-sonar mosaic of the offshore shoals. A, The shoals produce higher backscatter (lighter tones) than the wider and shorter troughs. B, Shoal slope angles overlain on the sidescan-sonar mosaic, with contour intervals indicating depth in meters below sea level (mbsl). Data from Pfeiffer and others (2011). db, decibel.

Sediment cores collected from the shoals contain tan to gray 85-98 percent medium to fine sand (median: 0.23-0.28 mm) with trace amounts of shell fragments. The deposits exposed in the intershoal areas comprise a thin (1-2 $\mathrm{m}$ ) covering of the underlying pre-Holocene sediments. These transgressive deposits are reworked inner-shelf and open-bay sediments and are described in the USACE cores as predominantly silts and clays with a trace of fine-grained sand and shell material. A few of the cores contain a thin $(0.5 \mathrm{~m})$ veneer of muddy sand at the seafloor which may increase backscatter in the sidescan-sonar signal.

\section{Physical Setting, Study Area 3 (Ship Island Pass at Cat Island)}

The pass between Ship and Cat Islands is approximately $8 \mathrm{~km}$ wide and varies in depth from less than $1 \mathrm{~m}$ adjacent to Cat Island to over $12 \mathrm{~m}$ at the maintained shipping channel (fig. 22). The ship channel runs along the eastern edge of the pass and was moved westward at Ship Island to accommodate migration of the island (fig. 22). Other than the channel, the pass is generally less that $5 \mathrm{~m}$ deep and is occupied by dredge spoil banks and natural shoals. Several shoal features are identified in the high-resolution bathymetric map. The spoil deposits associated with excavation of the ship channel are also visible. The largest shoal, adjacent to the northeast tip of Cat Island, covering approximately $5 \mathrm{~km}^{2}$, is located in $4 \mathrm{~m}$ of water and extends to within $2.5 \mathrm{~m}$ of the surface (fig. 23). The western end of the shoal is amalgamated with the northern spit of Cat Island, although the two deposits appear to be distinct. The shoals are not readily discernible in the sidescan-sonar mosaic due to the wide spacing of the survey tracklines and shallow water depth. 


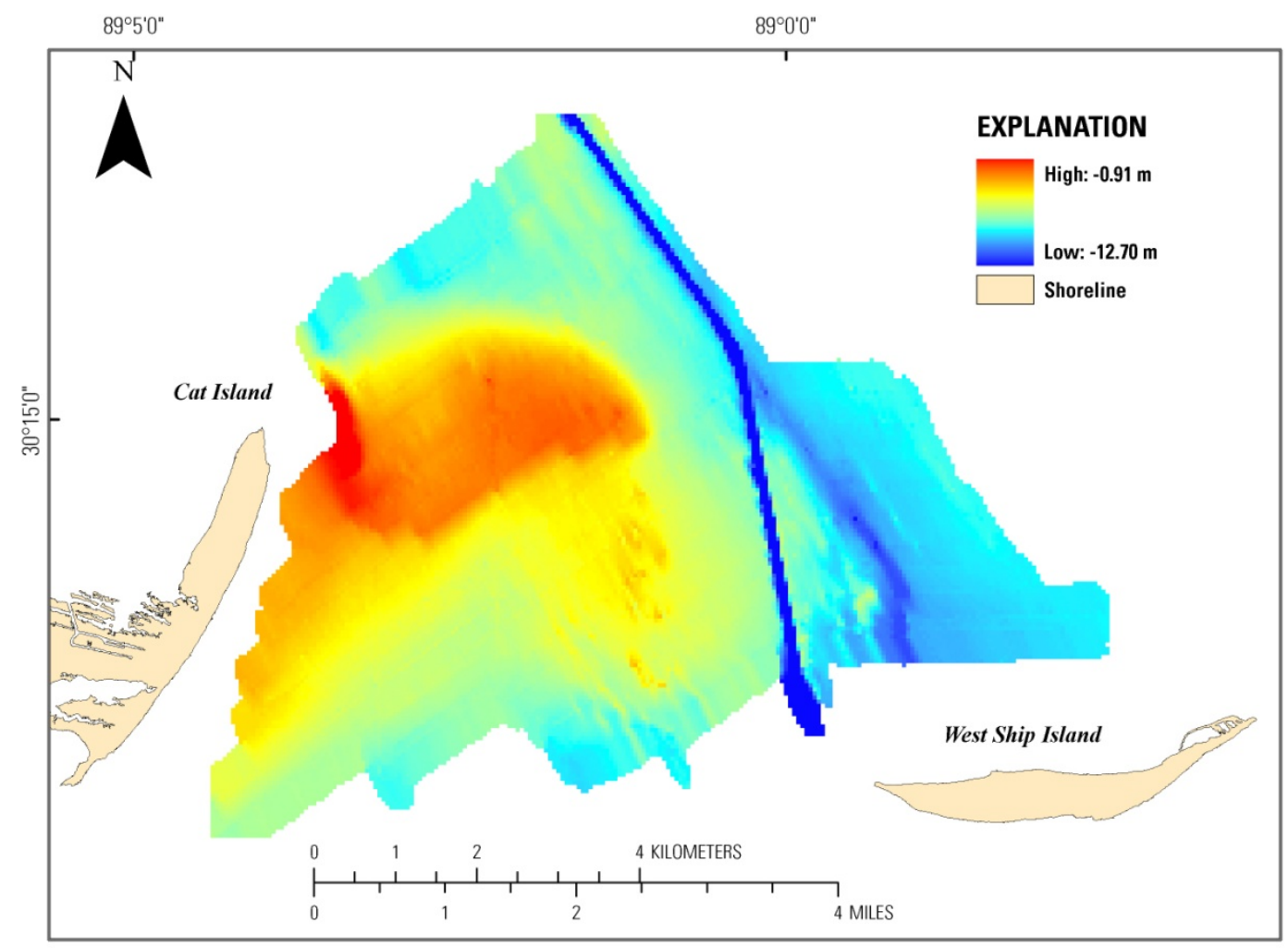

Figure 22. Bathymetry of Study Area 3 showing shoals and spoil deposits. Dark blue line is shipping channel. 


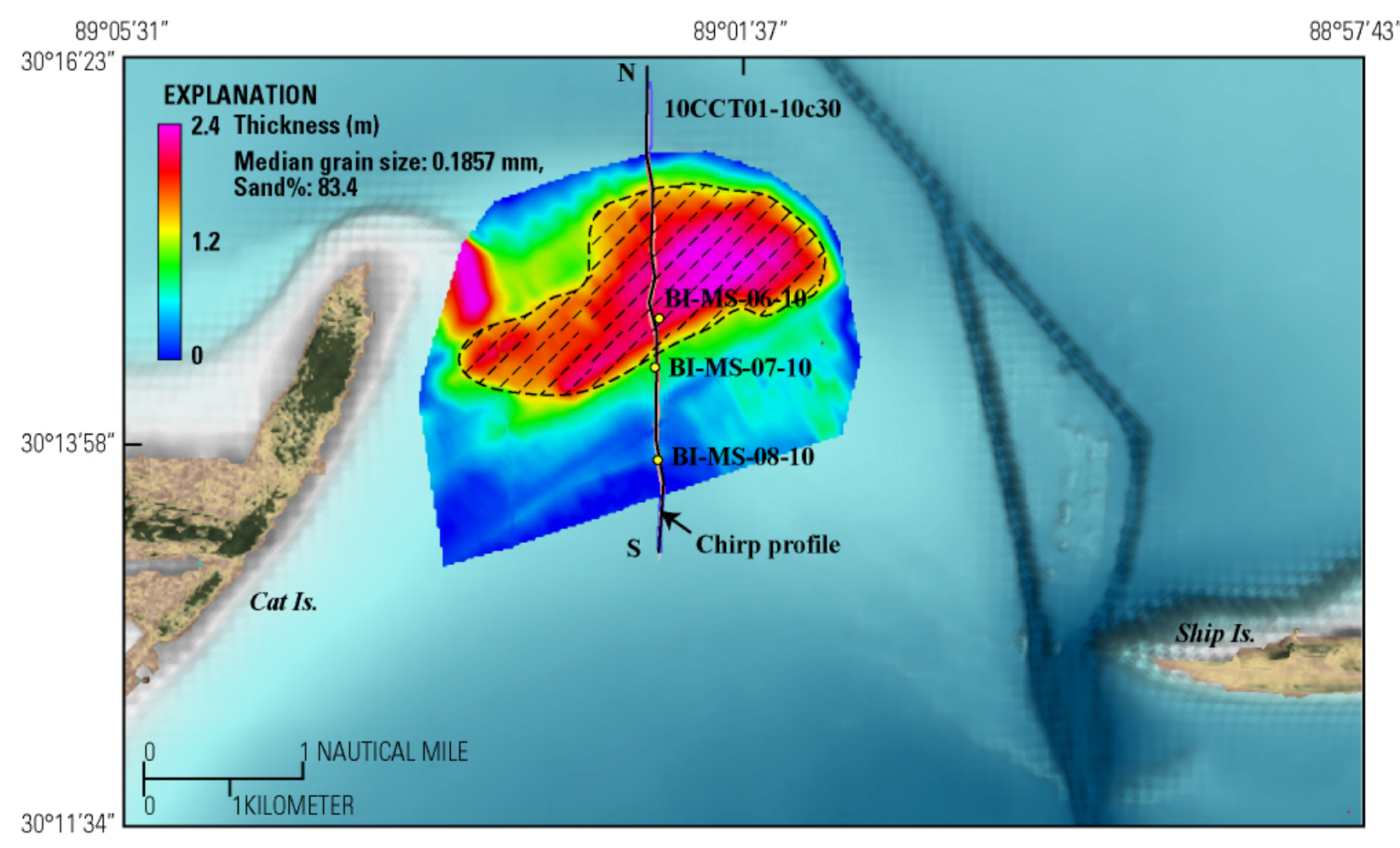

Figure 23. Shaded relief map of Ship Island Pass (Study Area 3) with location and isopach of shoal deposit (hatched area). Location of Chirp profile and cores shown in figure 24 are shown on map.

Chirp profiles of the shoal reveal the area of relief is composed of two overlying deposits separated by a faint, discontinuous reflector (fig. 24). The lower unit is approximately $1.25 \mathrm{~m}$ thick and extends seaward of the upper unit, which is $1 \mathrm{~m}$ thick and has a tapered shoreward side and steep scarp on the seaward side. Sediment cores from these units are composed of gray sand that coarsens upward. The lower unit is a gray silty sand, with an average sand constituent of 83 percent fine sand $(0.185 \mathrm{~mm})$. Non-sand content ranges from 14-20 percent. The upper unit is gray sand, with an average of 97 percent fine sand $(0.19 \mathrm{~mm})$. Both units contain trace shell fragments. Thickness of the upper unit is shown in figure 24. Volume estimates of the lower unit are $18.75 \times 10^{6} \mathrm{~m}^{3}$ of sediment and $15.6 \times 10^{6}$ $\mathrm{m}$ of sand. The upper unit contains $7.0 \times 10^{6} \mathrm{~m}^{3}$ of sediment and $6.8 \times 10^{6} \mathrm{~m}^{3}$ of sand. 

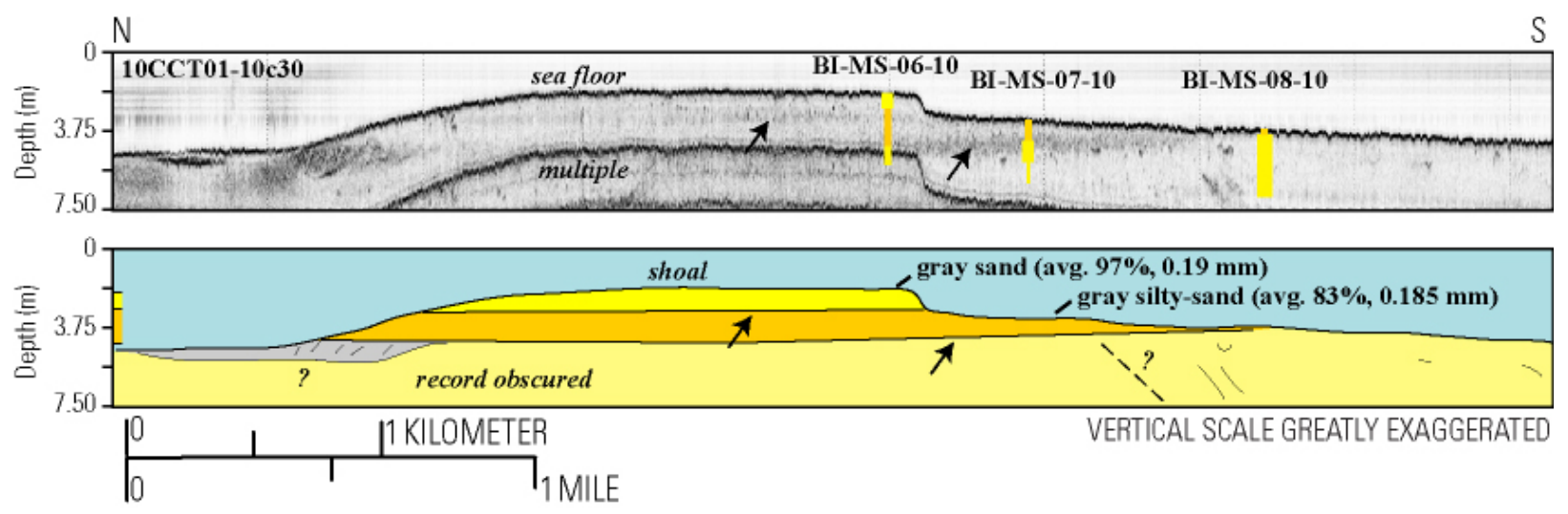

Figure 24. Chirp profile across shoal and interpretation show the two units that comprise the shoal (upper and lower). Profile location shown in figure 23. Core locations are shown with sand content represented by bar thickness. Zero (0) on the vertical scale of the seismic profile is relative to the sea surface. Chirp data from Forde and others (in press).

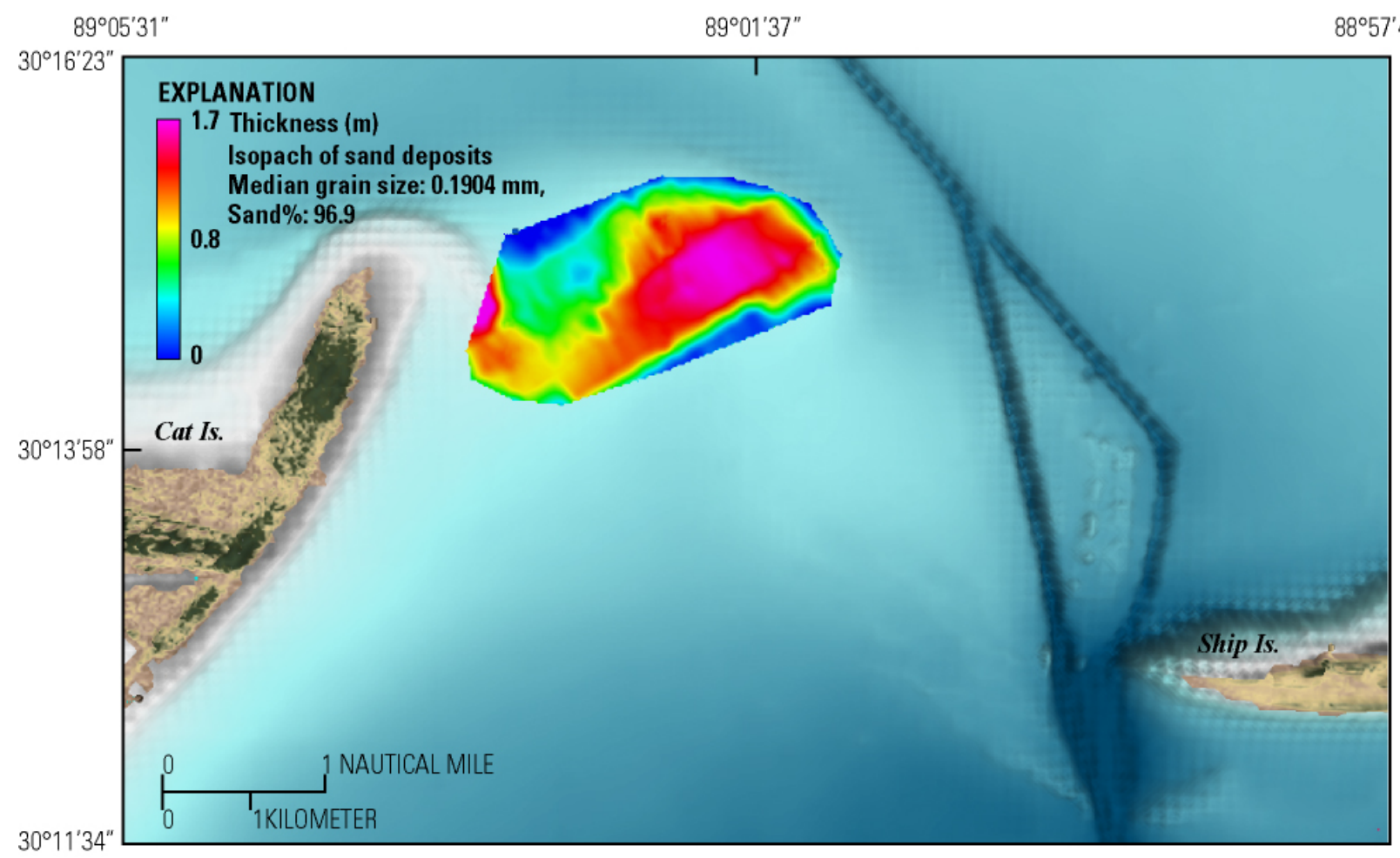

Figure 25. Isopach map of the upper unit of the shoal in Study Area 3.

Due to the proximity of the Chirp transducer to the seafloor in the shallow water, and massive sands of the shallow stratigraphy, the Chirp system could only image the upper $7 \mathrm{~m}$ of sediment. Sediment cores acquired at most the top $6 \mathrm{~m}$ of sediment, so stratigraphy below the shoal deposits could not be determined. 


\section{Discussion}

\section{Geologic Evolution of the Mississippi Inner Shelf}

A conceptual model of Holocene geologic evolution has been developed for the western Mississippi inner shelf based on the seismic stratigraphic reconstruction (fig. 26). The following paragraphs discuss how the stratigraphic relations of unconformities and depositional units are interpreted to infer significant Holocene geologic events. Because no age dating was conducted for this study, the temporal framework for the model is drawn from studies conducted in adjoining areas, including the Mississippi barrier islands (Otvos, 1981; Otvos and Giardino, 2004) and the Mississippi Delta Complex (Frazier, 1967). 
Present-2,000 yr B.P.

Barrier island system rebuilds (by westward deposits, but shoreward of initial barrier location. Waves and inner shelf circulation transport mud from Mobile Bay and tidal delta sand westward to form the modern shelf deposit.

2,000-4,000 yr B.P.

St. Bernard Delta advances eastward, burying the shelf mud deposit and parts of the barrier island chain and tidal delta. progradation) over abandoned St. Bernard Delta
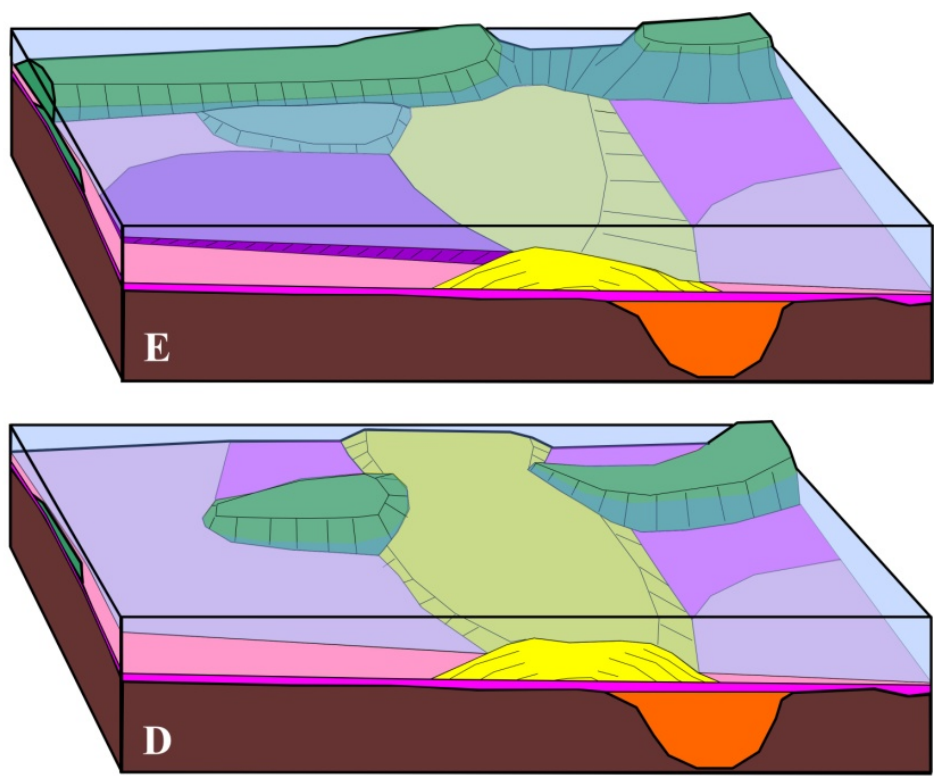

$\sim 4,000-4,600$ yr B.P.

Barrier island chain interrupted by tidal delta, and both the islands and tidal delta partially bury the shelf mud deposit.

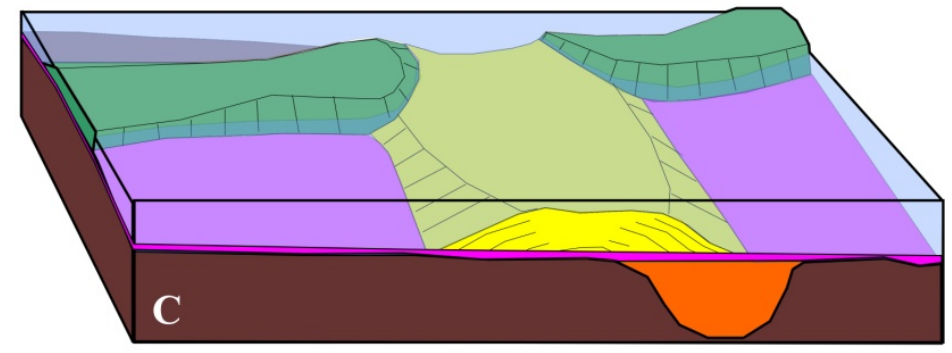

4,600-8,000 yr B.P.

Rising sea level floods valleys, which fill with deltaic and estuarine sediments. Subsequently a thin veneer of mud blankets the shelf.

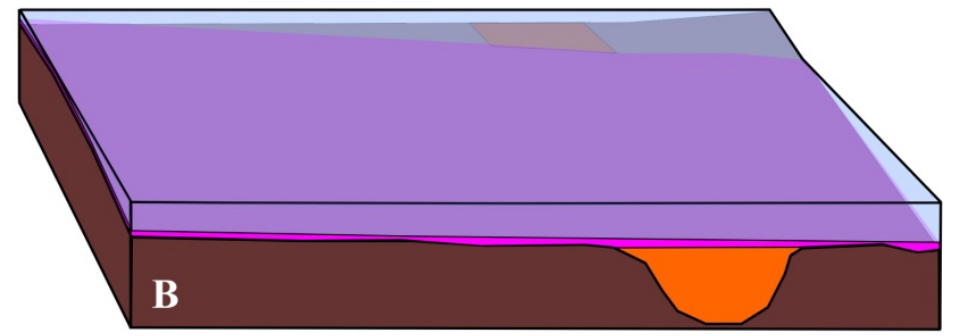

$8,000-10,000$ yr B.P.

Lowstand of sea level and valleys eroded by fluvial incision.

\section{EXPLANATION}

Modern inner shelf deposit

Middle to late Holocene St. Bernard delta deposits

Middle Holocene tidal delta

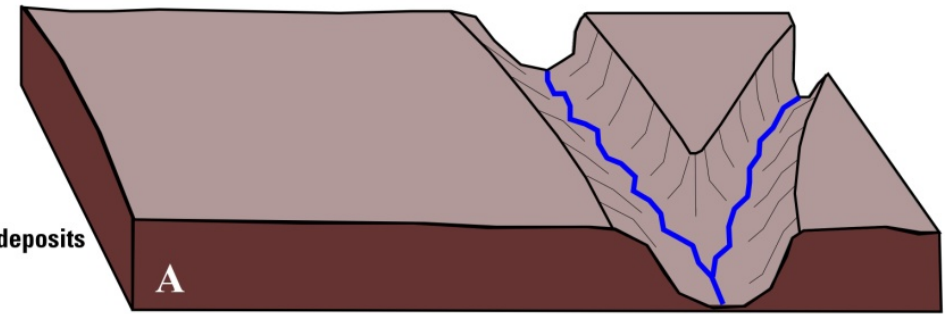

Middle Holocene barrier island deposits

Middle Holocene muddy shelf deposit

Early Holocene valley-fill deposits

Pre-Holocene deposits

Figure 26. Conceptual illustration showing the five major steps in the Holocene evolution of the Study Areas 1 and 3 as derived from the seismic and coring results. Sandy deposits include the tidal delta deposit (yellow) and barrier island deposits (green) that formed since 4,600 yr. B.P. and are shown in sections C, D, and E of the illustration. The remainder of the present shelf surface is mud. See text for discussion. 


\section{Western Mississippi Barrier Islands (Study Areas 1 and 3)}

The valleys in the lowstand erosional unconformity were incised by rivers flowing offshore across Study Areas 1 and 3 during the last Pleistocene lowstand of sea level (figs. 9 and 26A). Seaward of this area, Kindinger (1989) mapped extensions of this network southward across the Mississippi shelf and interpreted them as remnants of the fluvial systems that supplied sediment to the Lagniappe Delta at the shelf edge. As sea level rose during the early Holocene, the fluvial valleys were flooded and the shoreline retreated across the shelf. The thalwegs of the valleys are $18-29 \mathrm{~m}$ below sea level within Study Area 1, and a sea-level curve for the northern Gulf of Mexico (Balsille and Donoghue, 2004) suggests this region would have flooded approximately 8,000-10,000 yr B.P. As the valleys flooded, they were filled with bayhead delta and estuarine deposits. By 6,000-7,000 yr B.P. Study Area 1 was completely submerged. During the transgression, coastal processes planed the upper surfaces of the Holocene-aged valley fills and older surrounding units to form a smooth ravinement surface (fig. 11). During the middle Holocene (4,600-8,000 yr B.P.), mud and sandy mud were deposited unevenly across the marine transgressive unconformity (figs. 11 and 26B). Borings reported by Otvos (1981) and Otvos and Giardino (2004) show a 2-10-m-thick mud to sandy mud deposit overlying the Holocene marine transgressive unconformity below West Ship and Horn Islands but no equivalent deposit below East Ship Island, where barrier island deposits directly overlie the transgressive unconformity. On the inner shelf, the middle Holocene muddy deposit is absent along the northwestern part of Study Area 1 (fig. 13A), but offshore of East Ship Island it is $1.5-3 \mathrm{~m}$ thick and separates the marine transgressive unconformity from younger shelf deposits (figs. 11 and 13B).

Between approximately 4,000 and 4,600 yr B.P., an ancient analog of the Mississippi barrier island chain developed across the area (fig. 26C). The ancestral island chain and associated tidal inlets and shoals initially extended westward from the mouth of Mobile Bay, Ala., to the New Orleans, La., area (fig. 3, inset; Otvos, 1981; Otvos and Giardino, 2004; Stapor and Stone, 2004). Radiocarbon dates from the Mississippi part of the islands indicate that they were established by 4,600 yr B.P. (Otvos and Giardino, 2004). The acoustically massive unit overlying the ravinement surface in Ship Island Pass is interpreted to be one part of this ancestral coastal system (figs. 13A and 14). Seismic data only allowed mapping of the seaward edge of this unit, but it may be equivalent to a broader shoal that was proposed by Otvos (1981) in the same area. Cores from this area recovered sand and muddy sand that is texturally similar to sediments found in the lower parts of drill holes collected on the barrier islands (Otvos, 1981).

The acoustically massive unit south of Camille Cut and East Ship Island is also interpreted to be part of the ancestral barrier island chain (figs. 13B and 14). The narrow western extension of this unit, which coincides with the location of Loggerhead Shoal, is interpreted to be part of a relict barrier island, while the semicircular eastern part is interpreted as an adjacent tidal delta (fig. 26C). Cores from both areas recovered sand and muddy sand that is texturally similar to the sediment in drill holes from the present islands (Otvos, 1981). Alternatively, the semicircular portion of this unit could be interpreted as a fluvial delta, but the absence of organic debris, the presence of shell fragments, and the proximity of this deposit to the adjacent barrier island seem more consistent with a tidal delta origin.

As sea level continued to rise, the original islands would migrate shoreward. Large parts of the ancestral barrier island chain were then buried between 2,000 and 4,000 yr B.P. by the St. Bernard Delta, which started advancing eastward from the New Orleans area about 4,000 yr B.P. It built eastward until approximately 2,000 yr B.P., when it was abandoned due to channel avulsions that redirected the Mississippi River and its load of sediment south (Frazier, 1967). At its maximum extent, the distal part of the St. Bernard Delta covered the western half of Study Area 1(figs. 16 and 26D). These distal deposits show on seismic profiles as a series of closely spaced parallel reflections 
(fig. 15A). Deltaic deposits are greater than $7 \mathrm{~m}$ thick in the southwestern corner of Study Area 1, which was closest to the axis of the St. Bernard Delta, but thin away from this point to the north and east. In the northwestern corner of the Study Area the onlapping delta unit forms a thin cover across Ship Island Pass shoal (fig. 13A). To the east the unit thins to about $1.5 \mathrm{~m}$ prior to onlapping the edge of the tidal delta off Ship Island (fig. 13B and 14). The top of this tidal delta was not buried by St. Bernard Delta deposits (fig. 26D).

By the time the St. Bernard Delta was abandoned, the barrier islands had migrated shoreward of Study Area 1, presumably due to the forcing of overwash processes (figs. 16 and 26E). Loggerhead Shoal and the tidal delta south of Ship Island appear to be remnants of the ancestral barrier system that still remain exposed on the seafloor (fig. 14). The burial of much of the St. Bernard Delta unit south of West Ship Island indicates that shelf sediments continued to accumulate during this time (figs. 15B, 26E). The westward dip of reflectors within this unit suggests that its deposition was driven by westward transport of sediment across this part of the inner shelf. The fact that the deposit overlies the St. Bernard Delta unit indicates that it formed during the last 2,000 years. Cores from this deposit were visually described as being composed of clay (John Baehr, USACE, unpublished data, [8 Feb., 2011]) although the high-backscatter sidescan-sonar signature from the surface of this deposit (fig. 7) and the dipping reflectors within the deposit (fig. 15B) suggest that alternating layers of silt and sand deposits are present. It is likely that the silt and sand components were too small or thin for the general classification used in describing the cores.

The youngest deposits are indicative of the impacts of anthropogenic activities on the Mississippi inner shelf during historic time. The dredge spoil mounds located on either side of the Gulfport Ship Channel are the result of dredging activities aimed at maintaining its required depth for navigation (fig. 17). Cores recovered from the mounds between Ship and Cat Islands consist of muddy sand, while cores from those near the southern edge of Study Area 1 were described as consisting of only mud. The reason for this textural difference may be attributed to the coastal littoral system.

Cipriani and Stone (2001) found that the alongshore sediment transport along the Mississippi barrier islands is consistently to the west. West Ship Island is at the western end of this littoral system, and some of the sand that escapes is deposited in the ship channel off the western end of the island, and once dredged, this material is deposited on the northern of the two mounds. Farther to the south, where the shelf surface surrounding the ship channel is composed of mud, only fine-grained sediment is available to be resuspended by shelf processes and transported to and deposited in the southern part of the channel, and here the dredged material is finer grained.

\section{Eastern Mississippi Barrier Islands (Study Area 2)}

In the eastern portion of the Mississippi barrier islands, the near-surface stratigraphy of the inner shelf is the product of fluvial-deltaic processes, followed by marine transgression and barrier-island development. Across the inner shelf, a regional unconformity is recognized in the stratigraphic record that marks the last sea-level lowstand (marine oxygen isotope Stage 2). This surface truncates underlying reflections and defines broad valleys incised into the Pleistocene surface (Greene and others, 2007). North of the islands, the fluvial systems were fed by the Fowl and Bayou La Batre watersheds (fig. 1). Buried distributary deposits have been mapped originating from these sources and extending across Mississippi Sound to Petit Bois Pass (Green and others, 2007). Interpretation of Chirp profiles in Study Area 2 shows that these deposits pass beneath the inlet and extend offshore (fig. 27A). The fluvial system is $4 \mathrm{~km}$ wide and depth to the thalweg is about $7.5 \mathrm{~m}$ below the seafloor. On the mid-shelf, the system merged with channels from the Pascagoula and Pearl watersheds to feed the Lagniappe and other shelf-edge deltas (Bartek and others, 2004). 

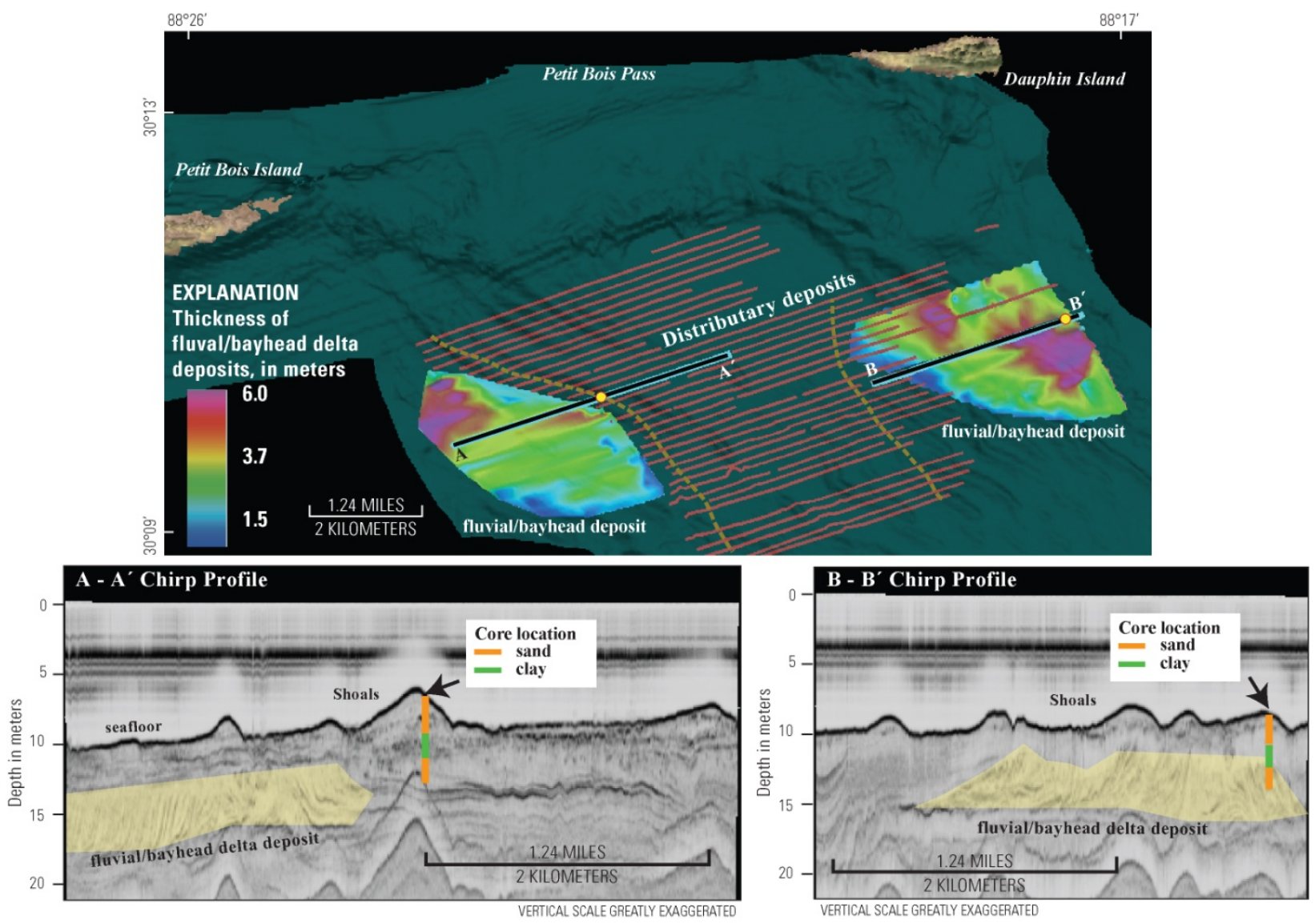

Figure 27. Trackline locations where buried distributary deposits are identified in Chirp profiles. The extent and thickness of two buried fluvial/bayhead delta deposits are shown on the map and on two Chirp profiles=. Two cores (orange dots) showing sand deposits within the shoals and deeper units. Zero (0) on the vertical scale of the seismic profile is relative to the sea surface.

At the end of the last glacial maximum, sea-level rise flooded the incised valleys, which backfilled with fluvial and estuarine material (Bart and Anderson, 2004). Preservation of these valleyfill deposits provides the most complete stratigraphic history of the shelf. The distributary deposits (fig. 27) are flanked by high-amplitude, bi-directional, downlapping seismic reflectors (fig. 27, chirp profiles). This geometry has been identified in other studies on the shelf as channel-fill or bayhead-delta deposits (Bartek and others, 2004). Channel-fill deposits described in cores from Mississippi Sound contain bioturbated mixed clays and sand with wood fragments and shell material (Greene and others, 2007), and the 2010 USACE cores that penetrated these features offshore consist of poorly graded, medium sand and silt with a trace of shell fragments.

Another regional characteristic of the Pleistocene surface is a decrease in elevation seaward across the barrier islands. Within Mississippi Sound, sediment cores described in McBride and others (1991) place the Pleistocene contact between 5 and 10 mbsl. Greene and others (2007) describe paleohighs in the sound with elevations of 5 mbsl. On the gulf side of the islands, this surface drops to 17-20 mbsl. Otvos and Carter (2008) suggest the scarp is a remnant Pleistocene shoreline. McBride and others (1991) attribute the scarp to erosion during a Holocene transgressive stillstand which, along with 
increased sediment supply, allowed for the construction of the barrier shoreline (Swift and others, 1978). The top of the Pleistocene deposit below the barrier platform cannot be identified in Chirp profile due to depth and masking by acoustically massive sediments. Similar stillstands occurred across the middle shelf throughout the Holocene transgression, where similar scarps are observed below other shoals on the shelf (McBride and others, 1999). Along the Mississippi coast, as sea level reached its present position, the scarp defined the seaward edge of the Mississippi Sound and provided the nucleus for sediments driven by westward littoral transport, sourced from the Mobile Bay ebb-tide delta and offshore, to develop into shoals and ultimately the barrier islands of GUIS (Otvos, 1981). Within Study Area 2, radiocarbon dates indicate flooding and island formation began 5,000-4,000 yr B.P. (Otvos and Giardino, 2004; Greene and others, 2007).

The dominant Holocene facies on the middle Mississippi-Alabama shelf is an extensive sand sheet that extends from De Soto Canyon off Florida to the St. Bernard deltaic deposits east of the Mississippi River Delta. Due to its geographic extent, this facies has been called the MississippiAlabama-Florida (MAFLA) sand sheet and is characterized as moderately sorted, medium sand (Doyle and Sparks, 1980; McBride and others, 2004; Flocks and others, in press). These sediments are composed of reworked sediments from the valley-fill and transgressive marine deposits. The MAFLA sand sheet averages 2-3 m thick but is thicker where sediment has filled in fluvial channels and in the substantial shoal fields across the shelf (Kindinger 1989; McBride and others, 1999). Adjacent to the barrier islands, the sand sheet thins and is diluted by lagoonal mud. Cores within Study Area 2 indicate the sand sheet is thin $(<1 \mathrm{~m})$ to absent.

\section{Barrier Island Development}

The barrier islands off the Mississippi coast are part of an island chain that presently extends along the northern Gulf of Mexico coast for approximately $100 \mathrm{~km}$ (fig. 1). While these islands have existed for over 4,000 years, their locations and spatial extents have changed dramatically. This complex history needs to be reviewed and considered when assessing the suitability and potential of nearshore sediment deposits as mining resources.

Historical shoreline change shows a net westward shift in the location of the islands (Otvos, 1970; Morton, 2008), which has been attributed to strong westward littoral transport (Otvos, 1970; Cipriani and Stone, 2001; Morton, 2008). The western end of Horn Island extended westward approximately $5 \mathrm{~km}$ and narrowed due to erosion of its soundward and seaward sides over a period of 158 years (Morton, 2008). During the same time, Ship Island accreted approximately $1 \mathrm{~km}$ at its western end, eroded about $2 \mathrm{~km}$ at its eastern end, and after the breaching of Camille Cut, West Ship Island retreated slightly landward, while East Ship Island retreated landward by nearly $1 \mathrm{~km}$ (Morton, 2008). The location of Cat Island remained relatively stable over the same period, aside from some westward retreat of its eastern edge. Overall, Horn Island has receded more at the eastern end of Study Area 1 than the east-west- trending part of Cat Island has at the western end. In part, this difference in island retreat has been attributed to the influence of St. Bernard Delta antecedent topography on the wave approach and refraction along the Mississippi barrier islands. Rucker and Snowden (1989) suggested that the "T" shape of Cat Island was a consequence of the change in incoming wave direction caused by eastward advance of the St. Bernard Delta. The counterclockwise rotation of Ship Island documented by Morton (2008) may represent a similar result. In this instance, Ship Island is not as sheltered by the trend of the St. Bernard Delta, so wave refraction and the resulting reorientation of the island has not been as extreme. One consequence of the counterclockwise rotation of Ship Island is that part of the pre-St. Bernard Delta island chain is still exposed on the seafloor (fig. 26E). 
The ancestral Mississippi barrier island chain was nearly twice the length of its modern analog, extending at least to New Orleans (fig. 3, inset), but advance of the St. Bernard Delta largely buried its western half (Otvos, 1981; Otvos and Giardino, 2004; Stapor and Stone, 2004). Optically Stimulated Luminescence (OSL) dates verify the difference in age east and west of Cat Island (Otvos and Giardino, 2004). OSL dates from beach ridges on Cat Island and the islands farther to the west all predate St. Bernard Delta deposits, while dates from recurved spit ridges on Ship and Horn Islands are younger than the St. Bernard deposits. Despite the differences in island age, fine to medium sands compose the cores of both the ancestral island remnants west of Cat Island and the modern islands to the east (Otvos, 1981; Otvos and Giardino, 2004; Stapor and Stone, 2004). Only Dauphin Island at the very easternmost end of the island chain has different material at its core. Pleistocene and older deposits form the core of the eastern part of this island (Otvos and Giardino, 2004). Borings through Ship and Horn Islands indicate that for much of their length they are built upon muddy to sandy mud deposits containing a marine biofacies (Otvos, 1981). Overlying the muddy shelf deposits is a thick interval (6-15 m) of poorly sorted muddy sand that is capped by a thinner layer $(<6 \mathrm{~m})$ of well-sorted sand. The absence of mud in the uppermost unit of the barrier deposit indicates that the present inner shelf, which is dominantly covered with muddy sediment (figs. 7 and 28), supplies very little sediment to the western barrier system. Within Study Area 1, the relict tidal delta off Ship Island is the only potential inner shelf source of sand-sized sediment, and it covers only 6 percent of this Study Area. 


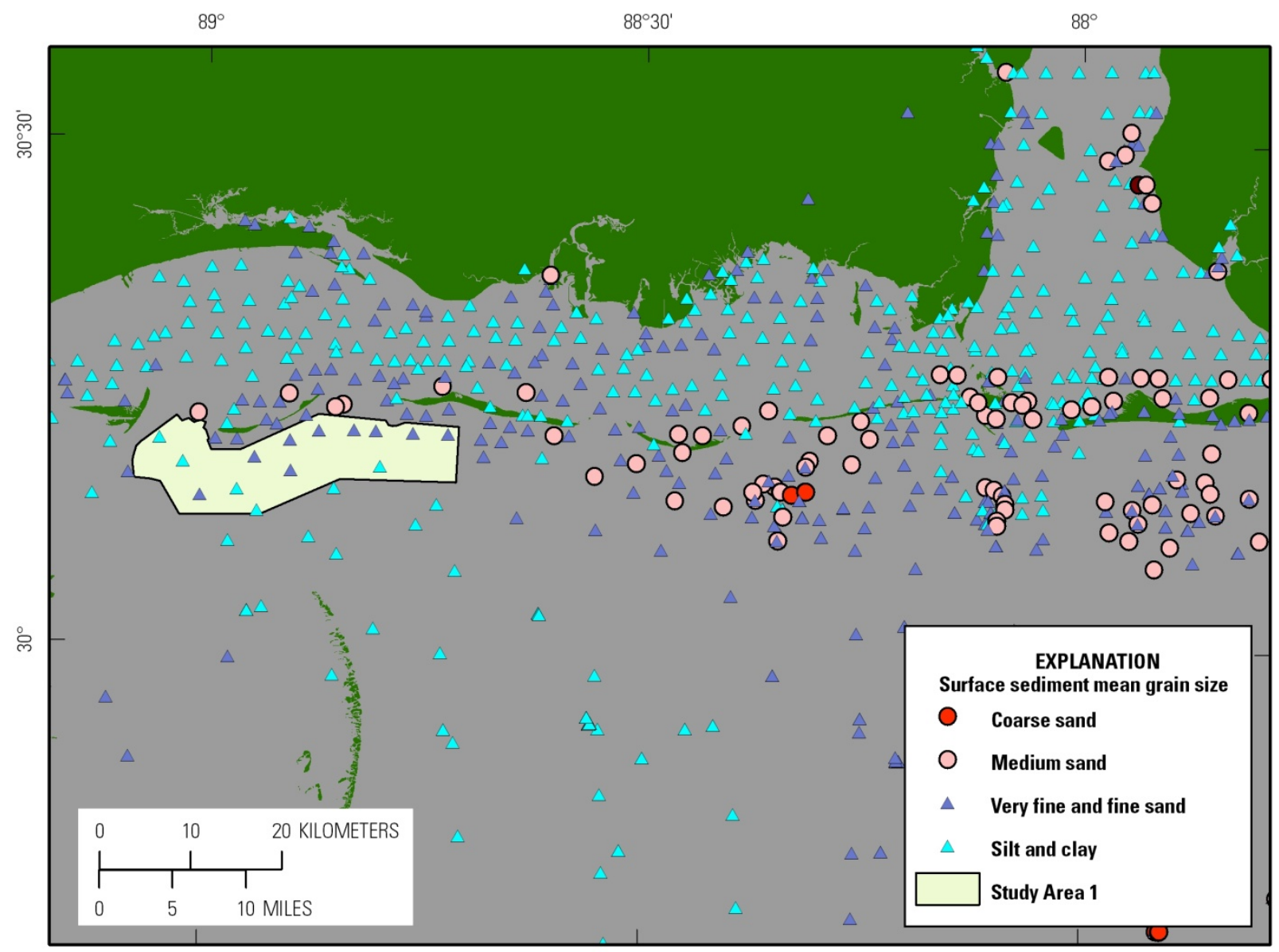

Figure 28. Map showing the distribution of the mean grain size of surface sediment samples contained in the USGS uSSEABED database (Williams and others, 2007). The only location where surface samples with a mean grain size of coarse sand were reported is off Petit Bois Pass.

The sediment recovered in drill borings through the Mississippi barrier islands and vibracores from the shoals and tidal deltas offshore of these islands is predominantly fine to medium sand or muddy sand (Otvos, 1981), yet samples from the lower foreshore along the entire island chain from Mobile Bay to Ship Island consist of coarse sand (Cipriani and Stone, 2001). Farther up the beach, samples from the mid-tide level and foredune crest were medium sand. The concentration of coarse sand in the lower foreshore is likely due to the higher expenditure of wave energy in this zone, but the source of the coarse sand is unclear. A local offshore source is unlikely, as the only sand exposed on the seafloor within Study Area 1 is on Loggerhead Shoal and the tidal delta east of the shoal. Samples from these two areas are composed primarily of medium and fine sand and on average contain only 7 percent coarse sand. Substantial winnowing would be required for these deposits to be a significant source. A more likely source is the inner shelf east of the survey area, offshore of Petit Bois Island near Study Area 2, where surface sediment samples were collected from localized patches of coarse sand exposed on the inner shelf (fig. 28). The eastern, updrift location of this source is consistent with the net 
westward littoral transport observed along the island chain (Cipriani and Stone, 2001); however, the bathymetry change analysis (fig. 20) suggests limited exchange between the shelf and coastal system.

\section{Potential Sand Resources}

Through analysis of the geophysical and sedimentologic data, seafloor and subsurface deposits have been identified that may provide suitable material for shoreline restoration projects (fig. 29). The deposits are related to pre-Holocene fluvial processes, or modern shoaling and tidal processes. Sand content in these deposits is highly variable but is greatest in the shoaling and tidal deposits. The older

fluvial deposits may be covered by 1-2 $\mathrm{m}$ of muddy overburden. Of these features, primary targets for borrow material are described below. 


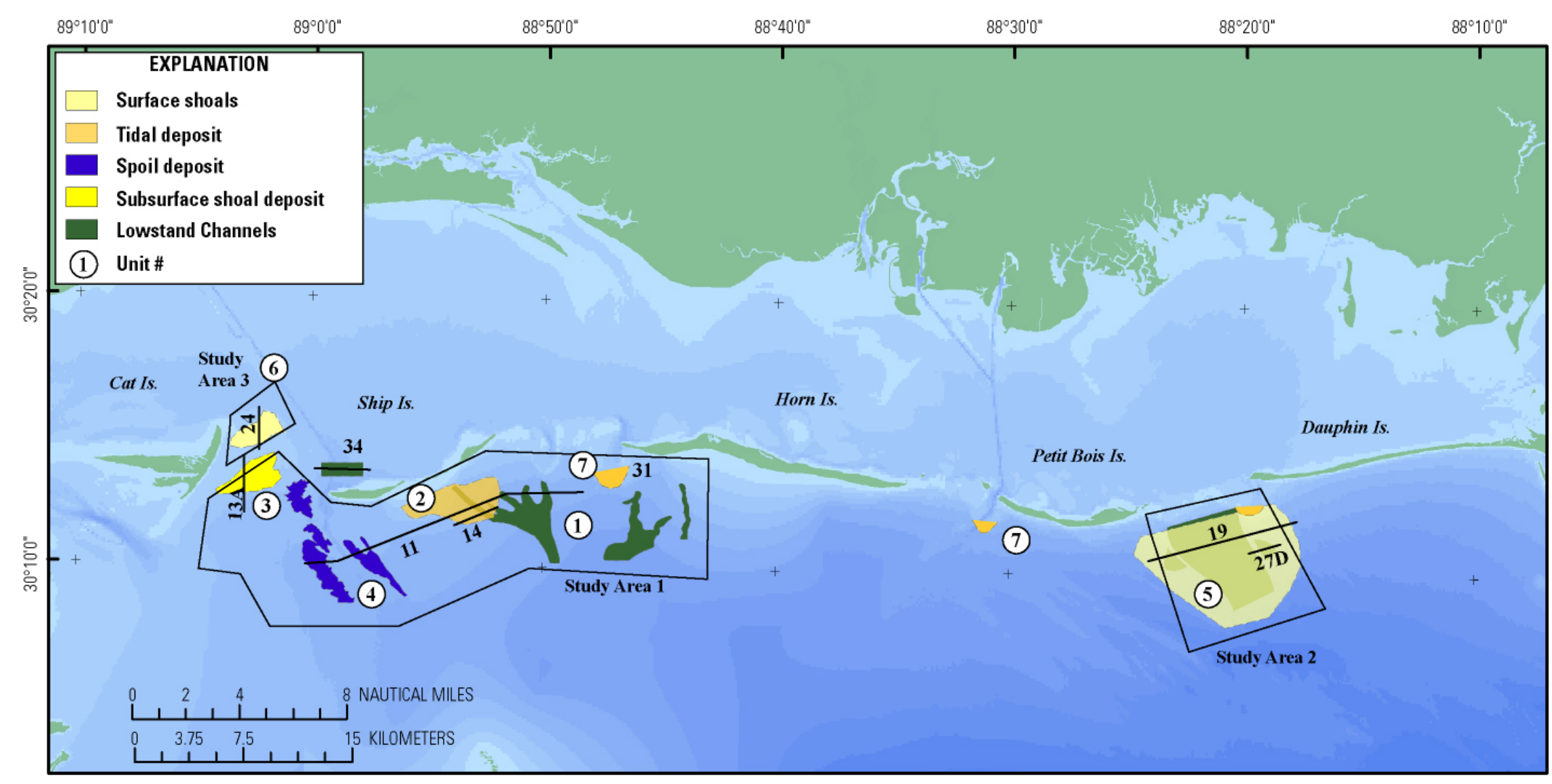

Figure 29. Locations of potential sand resources identified in this study. Each deposit is assigned a unit number that corresponds to textural information in table 1. Profiles provided in this report for each deposit are shown by location (black lines) and figure numbers. 
Table 1. Characteristics of potential sand-resource deposits located on the shelf offshore of the barrier islands off the western Mississippi coast.

\begin{tabular}{|c|c|c|c|c|c|c|c|c|}
\hline $\begin{array}{l}\text { Unit } \\
\text { Number }\end{array}$ & $\begin{array}{l}\text { Study } \\
\text { Area }\end{array}$ & Deposit & $\begin{array}{l}\text { Total } \\
\text { volume } \\
\left(\mathrm{x} 10^{6} \mathrm{~m}^{3}\right)\end{array}$ & $\begin{array}{l}\text { Volume of } \\
\text { deposit }>1 \mathrm{~m} \\
\text { thick } \\
\left(\mathrm{x} 10^{6} \mathrm{~m}^{3}\right)\end{array}$ & $\begin{array}{l}\text { Proximity to } \\
\text { Camille Cut } \\
(\mathrm{km})\end{array}$ & $\begin{array}{l}\text { Sediment } \\
\text { cover }(\mathrm{m})\end{array}$ & $\begin{array}{l}\text { Median } \\
\text { grain-size } \\
\text { range } \\
(\mathrm{mm})\end{array}$ & $\begin{array}{l}\text { Estimated } \\
\text { sand (\%) }\end{array}$ \\
\hline 1 & 1 & $\begin{array}{l}\text { Lowstand } \\
\text { Channels }\end{array}$ & $97^{*}$ & $70^{*}$ & $3-17$ & $>3$ & $\begin{array}{l}0.1694- \\
0.2778\end{array}$ & $25-75$ \\
\hline 2 & 1 & $\begin{array}{l}\text { Loggerhead } \\
\text { Shoal and } \\
\text { Tidal Delta }\end{array}$ & 40 & 29 & $1.5-6$ & 0 & $\begin{array}{l}0.1409- \\
0.3360\end{array}$ & $92-95$ \\
\hline 3 & 1 & $\begin{array}{l}\text { Ship Island } \\
\text { Pass Shoal }\end{array}$ & 7* & 4* & $9-14$ & $<1$ & $\begin{array}{l}0.1275- \\
0.1992\end{array}$ & 94-97 \\
\hline 4 & 1 & $\begin{array}{l}\text { Dredge } \\
\text { Spoil }\end{array}$ & 11 & 2 & $8-10$ & 0 & $\begin{array}{l}0.1991- \\
0.2030\end{array}$ & $30-96$ \\
\hline 5 & 2 & $\begin{array}{l}\text { Petit Bois } \\
\text { Shoals }\end{array}$ & 56 & $2-22$ & 52 & 0 & $\begin{array}{l}0.2300- \\
0.2800\end{array}$ & $>90$ \\
\hline 6 & 3 & $\begin{array}{l}\text { Cat Island } \\
\text { Shoal }\end{array}$ & 25 & 20 & 10 & 0 & $\begin{array}{l}0.1850- \\
0.1900\end{array}$ & $88-97$ \\
\hline 7 & 1 & $\begin{array}{l}\text { Modern ebb- } \\
\text { deltas }\end{array}$ & $>6$ each & $>4$ each & $11,33,50$ & 0 & $\begin{array}{l}0.1600- \\
0.2300\end{array}$ & $94-99$ \\
\hline
\end{tabular}

* Volumes only for the part of the deposit within the Study Area.

\section{Study Area 1 (offshore Ship Island)}

Seismic-reflection and vibracore data indicate that the shallow stratigraphy of the western Mississippi inner shelf mainly consists of fine-grained sediment, but four potential borrow areas have been identified within Study Area 1 for mining sand-sized material (fig. 30). The target areas include the lowstand channels, the tidal delta off East Ship Island, the submerged Ship Island Pass shoal, and the dredge spoil mounds. The characteristics of each site are summarized in table 1 and discussed in the following paragraphs. 


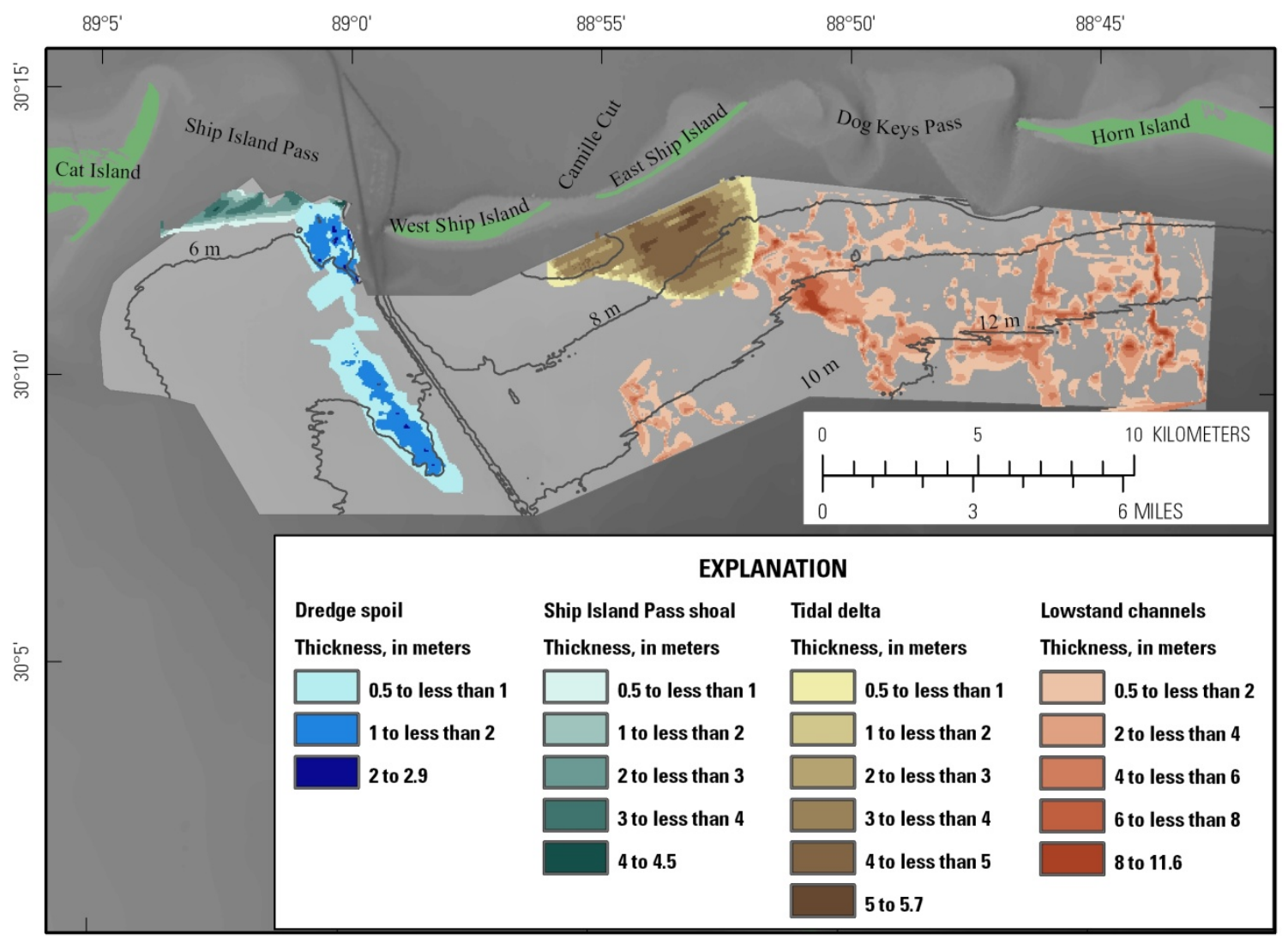

Figure 30. Map showing the distribution and thickness of four potential sand resource targets within Study Area 1. The volume and range in median grain size for each of these deposits is given in table 1.

Within Study Area 1, the lowstand channels represent the largest target area, containing a total volume of approximately $97 \times 10^{6} \mathrm{~m}^{3}$, with $70 \times 10^{6} \mathrm{~m}^{3}$ being in areas where the deposit is greater than $1 \mathrm{~m}$ thick (table 1). These deposits are mostly long, linear features that can extend up to the entire $6.5 \mathrm{~km}$ width of the surveyed area (fig. 30). Large parts of these valley fills are more than $5 \mathrm{~m}$ thick, but they are also generally narrow, between 200 and $400 \mathrm{~m}$ wide. One exception is where three tributaries in the westernmost channel system converge to form a deposit approximately $1 \mathrm{~km}$ wide and $2 \mathrm{~km}$ long (fig. 12). The median grain size of the limited number of samples from these deposits is fine to medium sand (fig. 29). The deposits are 3-17 km from the Camille Cut restoration area. A major complicating factor in extracting this resource is that these deposits are all buried beneath 2.5- $6 \mathrm{~m}$ of muddy sediment (figs. 11 and 12, profile).

The former tidal delta deposit that lies south of East Ship Island contains a total volume of approximately $40 \times 10^{6} \mathrm{~m}^{3}$, with $29 \times 10^{6} \mathrm{~m}^{3}$ of the deposit being greater than $1 \mathrm{~m}$ thick (table 1). The deposit stretches along the front of East Ship Island for $9 \mathrm{~km}$, is as much as $5 \mathrm{~km}$ wide, and reaches $5.7 \mathrm{~m}$ in thickness (fig. 30). The median grain size of samples from these deposits is fine to medium sand. The deposit is 1.5-6 km from the Camille Cut restoration area. Seismic data and cores show that this sandy deposit is exposed on the seafloor for much of its extent (fig. 14). 
The distal ends of the modern tidal deposits may also contain material suitable for sand resources. The ebb-tidal delta associated with Dog Keys Pass (fig. 31) contains deposits up to $4 \mathrm{~m}$ thick, with an estimated volume exceeding $4 \times 10^{6} \mathrm{~m}^{3}$. Cores collected in this deposit contain 94-99 percent sand (median grain size: $0.16-0.23 \mathrm{~mm}$ ). The majority of the ebb-tidal deltas that occur within GUIS boundaries are located adjacent to active tidal inlets. Removal of sediments from the inlets could destabilize the system, enhance tidal scour, and disrupt littoral processes.

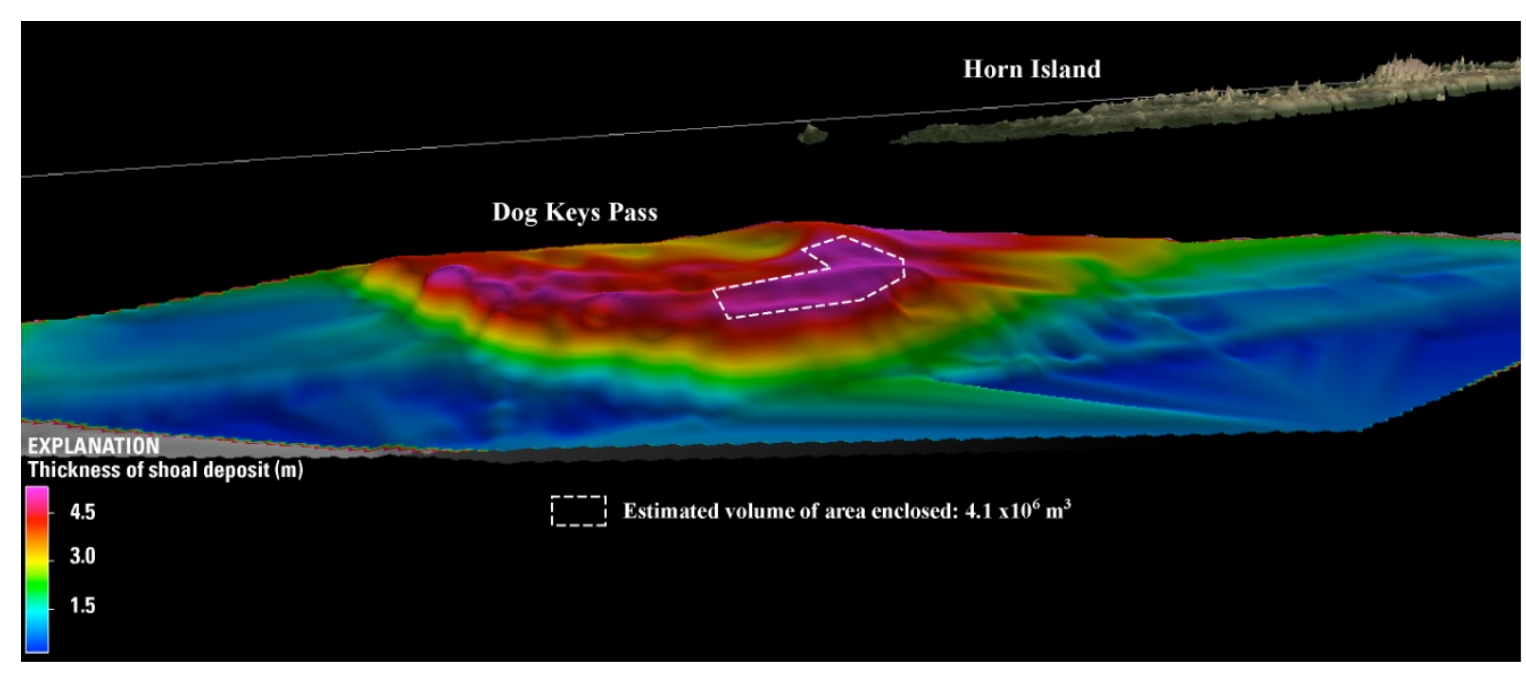

Figure 31. Isopach perspective of the seaward end of Dog Keys Pass ebb-tidal delta in Study Area 1 (see fig. 29, unit 7, for location), interpreted from Chirp profiles.

The third target area is the buried Ship Island Pass shoal that straddles Study Areas 1 and 3 (figs. 29, 30, and 32). This feature trends along the axis of the barrier island system and is approximately $5 \mathrm{~km}$ long and $1.5 \mathrm{~km}$ wide and up to $3.5 \mathrm{~m}$ thick (figs $13 \mathrm{~A}$ and 14). Over $6 \mathrm{~km}^{2}$ of the deposit is greater than $1 \mathrm{~m}$ thick, with a volume of $13 \times 10^{6} \mathrm{~m}^{3}$. Two cores collected within the deposit contain 94-97 percent fine sand (table 1). Seismic profiles suggest that the deposit has $0.5 \mathrm{~m}$ of muddy overburden (fig. 13A). 


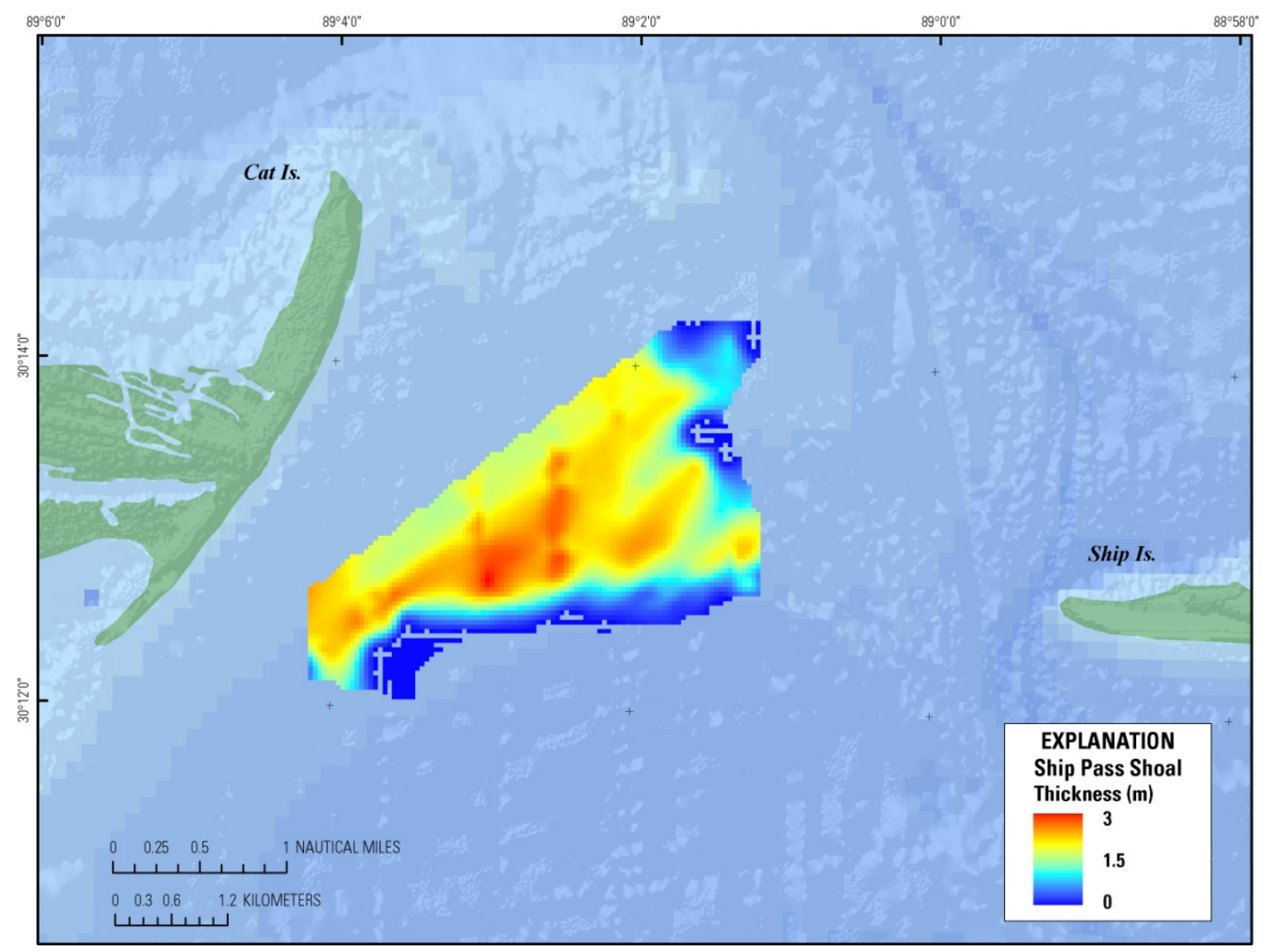

Figure 32. Isopach map of Ship Island Pass Shoal, interpreted from Chirp profiles. The subsurface deposit contains $1 \mathrm{~m}$ of muddy overburden.

The final target areas are the dredge spoil mounds west of the Gulfport Ship Channel (fig. 30). The total volume of sediment in the mounds is approximately $11 \times 10^{6} \mathrm{~m}^{3}$ but only $2 \times 10^{6} \mathrm{~m}^{3}$ in places where the deposit is greater than $1 \mathrm{~m}$ thick. Textural analyses of two cores that penetrated the dredge spoil (both from the northern part) indicate a median grain size of fine sand (table 1), although sand content in the spoil deposits is variable. The deposit is $8-10 \mathrm{~km}$ from the Camille Cut restoration area.

\section{Study Area 2 (Offshore Petit Bois Pass)}

The ebb-tide delta of Petit Bois Pass and the offshore shoal system contain $>90$ percent sand (fig. 29). The ebb-tide delta is $2.3-4 \mathrm{~m}$ thick and contains moderately well-sorted medium sand. The seaward edge of the ebb-tide delta deposit contains up to $14 \times 10^{6} \mathrm{~m}^{3}$ of sediment. Removal of sediments within the inlet itself would destabilize the system, enhance tidal scour, and further disrupt littoral processes. The offshore shoals contain poorly sorted medium sand (fig. 29). They range from 2-5 $\mathrm{m}$ in thickness (fig. 19) and are surrounded by a 1-2-m mantle of poorly sorted sandy silt. The shoals are vestiges of the marine environment prior to the present sea-level highstand. They are no longer active, and migration, if any, is slow or episodic. Due to depth and distance, the shoals do not contribute significantly to the littoral system that maintains the islands. The largest shoals are located in the southwestern part of Study Area 2 and possibly 
outside of the surveyed area. Figure 33 demonstrates the potential for additional resources within shoal systems to the southwest of the survey. Within this Study Area, fluvial deposits below the shoals may contain significant amounts of sand (fig. 27). There may be muddier deposits between the shoals and deeper fluvial deposits, but together the thickness of these deposits may include over $5 \mathrm{~m}$ of sandy material. Although the shoals did not evolve at the same time or through the same transgressive processes as the barrier islands, they originate from the same fluvial sources.

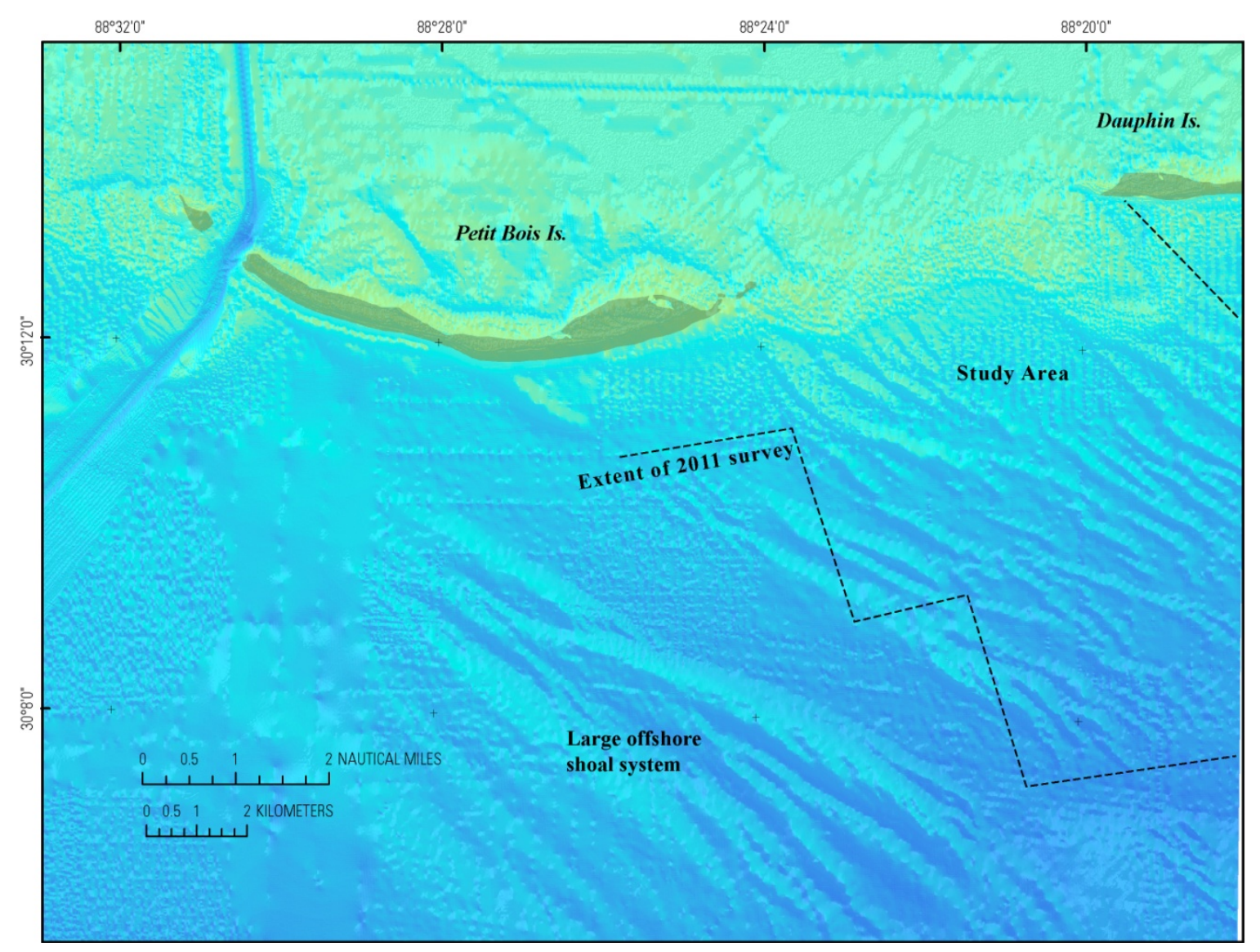

Figure 33. Regional shaded-relief perspective surrounding Study Area 2, to highlight shoals. Additional shoal systems farther offshore may contain significant volumes of sediment.

\section{Study Area 3 (Ship Island Pass at Cat Island)}

The shoal adjacent to Cat Island represents a large accumulation of sand in shallow water with no mud overburden (fig. 23). The shoal contains approximately $25 \times 10^{6} \mathrm{~m}^{3}$ of sediment with a sand content of at least 88 percent, with the uppermost meter providing 97 percent sand (fig 29). Analysis of bathymetric data from the late 1800s shows the shoal is a stable feature that has accreted approximately $1 \mathrm{~m}$ of sediment, likely from erosion of neighboring Cat Island shoreline. Shoal development was likely through similar processes that developed the rest of the Mississippi barrier islands and would contain compatible material to the island shoreface. 
Deeper deposits exist in this area related to pre-Holocene fluvial processes similar to those described in Study Area 2. Some of these features are shown in figure 34. These deposits contain variable amounts of muddy sands. On the sound-side of the barrier islands, these deposits are typically overlain by 1-2 m of estuarine mud.
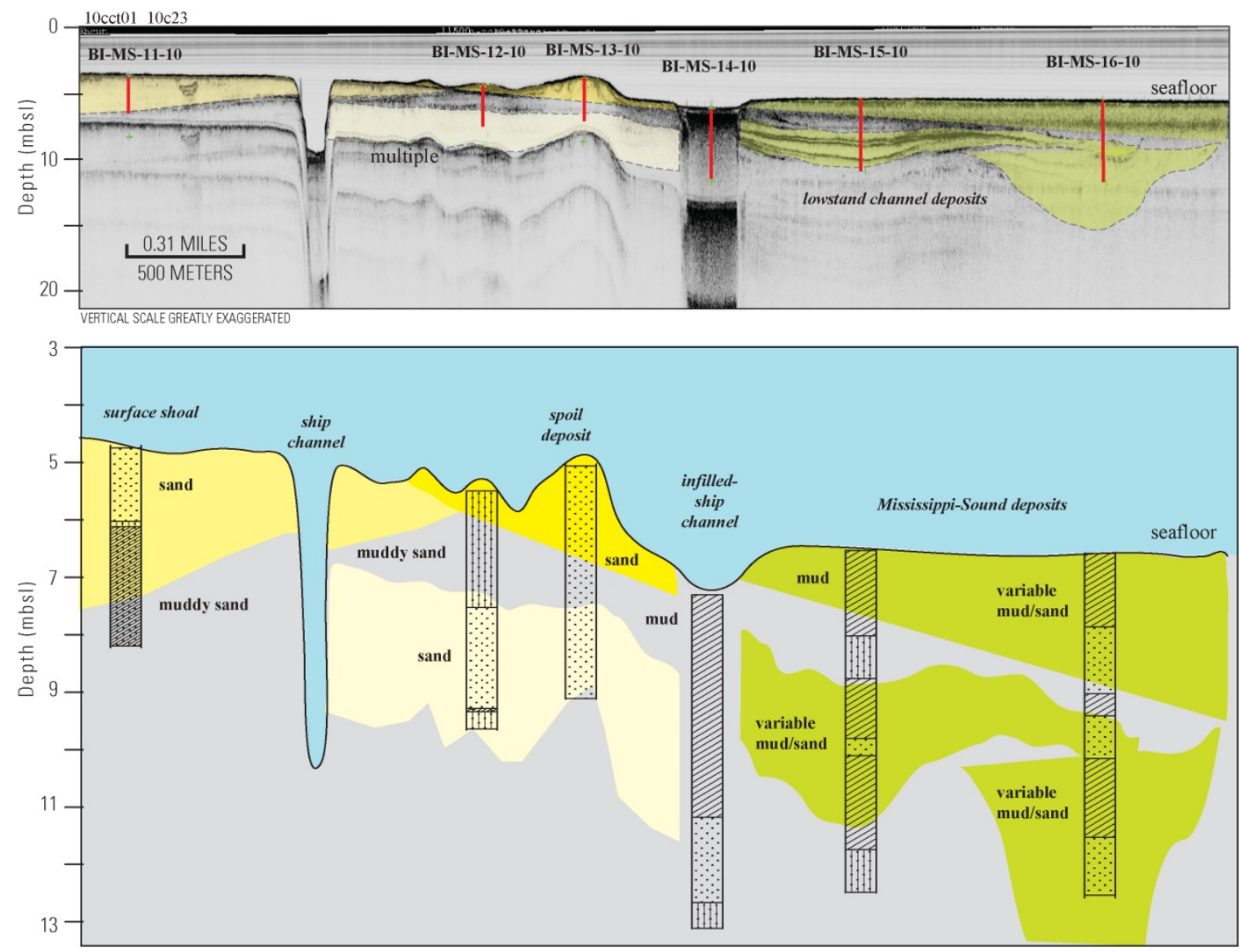

Figure 34. Chirp profile (top) and vibracores along a transect within Mississippi Sound showing the highly variable stratigraphy adjacent to the island platform. Zero (0) on the vertical scale of the seismic profile is relative to the sea surface. Profile location shown in figure 28. Deeper deposits, related to pre-Holocene fluvial processes identified in the offshore, contain variable amounts of sand. These deposits may also be overlain by estuarine mud and sand. 


\section{Conclusions}

Densely spaced, high-resolution seismic profiles and vibracore data have been used to investigate the shallow stratigraphy of the inner shelf offshore of the Mississippi barrier islands. The facies and distributions of inner shelf seismic units in three Study Areas were detailed and compiled into a stratigraphic reconstruction that was used to interpret the regional Holocene geologic history. During the last Pleistocene lowstand of sea level, large river valleys incised the inner shelf within this region. During the Holocene transgression, the valleys were flooded and filled with deltaic and estuarine deposits. By 4,000-5,000 years before present, sea level was within 3 meters of its present elevation when an ancestral Mississippi barrier island chain developed close to, or slightly seaward of, the location of its modern analog. Between approximately 4,000 and 2,000 years before present the St. Bernard Delta Complex of the Mississippi River advanced eastward and blanketed much of the inner shelf off the western Mississippi barriers with a layer of muddy sediment. The westernmost islands of the ancestral chain were partially to completely buried by the deltaic deposits, leaving only a tidal delta and some sections of the ancestral barrier complex partially uncovered. The shelf surface, both the sandy and muddy parts, has been reworked by inner shelf and anthropogenic processes. The parts of the Holocene stratigraphy that have the highest potential as borrow areas for mining sand-sized sediment include sandy, former tidal delta and barrier deposits associated with the initial island system, offshore shoals, and some of the dredge spoil deposits west of the Gulfport Ship Channel, while the lowstand channel deposits are probably not viable because they are too deeply buried. Because of the shallow ( $<10$ meters), nearshore locations of the potential borrow areas, hydrodynamic modeling studies will be needed to ascertain whether disruption of these deposits will disrupt or negatively impact the inner shelf transport system that may naturally supply sediment to the barrier islands.

\section{Acknowledgments}

We thank the captain and crew of the R/V Tommy Munro along with USGS technicians Dana Weise, Charles Worley, Emile Bergeron, and USGS scientists William Danforth and Aaron Turecek for their skilled assistance in the collection and processing of this extraordinary geophysical dataset. This report has benefited from discussions with D. Lavoie and J. Williams (USGS) and M. Byrnes (Applied Coastal Research and Engineering). Funding was provided by the U.S. Army Corps of Engineers and the U.S. Geological Survey. This report was reviewed by J. Denny, K. Scanlon, S. Dadisman, and K. Morgan.

\section{References Cited}

AML Oceanographic, 2011, Sound velocity SV Plus v2: Applied Microsystems, accessed 27 April, 2011, at http://www.amloceanographic.com/LinkClick.aspx?fileticket $=0 \mathrm{U} 4 \mathrm{zWzO}$ OPP4\%3d\&tabid=170

Balsille, J.H., and Donoghue, J.F., 2004, High resolution sea-level history for the Gulf of Mexico since the last glacial maximum: Florida Geological Survey Report of Investigations No. 103, $66 \mathrm{p}$.

Barry, K.M., Carver, D.A., and Kneate, C.W, 1975, Report on recommended standards for digital tape formats: Geophysics, v. 40, no. 2, p. 344-352. 
Bart, P.J., and Anderson, J.B., 2004, Late Quaternary stratigraphic evolution of the Alabamawest Florida outer continental shelf, in Anderson, J.B., and Fillon, R.H., eds., Late Quaternary stratigraphic evolution of the northern Gulf of Mexico margin: SEPM, Special Publication, v. 79 , p. 43-55.

Bartek, L.R., Cabote, B.S., Young, Tonja, and Schroeder, William, 2004, Sequence stratigraphy of a continental margin subjected to low-energy and low-sediment-supply environmental boundary conditions: late Pleistocene-Holocene deposition offshore Alabama, in Anderson, J.B., and Fillon, R.H., eds., Late Quaternary stratigraphic evolution of the northern Gulf of Mexico margin: SEPM Special Publication, v. 79, p. 85-109.

Buster, N.A., and Morton, R.A., 2011, Historical bathymetry and bathymetric change in the Mississippi-Alabama coastal region 1847-2009: U.S. Geological Survey Scientific Investigations Map. SIM 3154, 1 sheet, 13-p. pamphlet, accessed April 12, 2011, at http://pubs.usgs.gov/sim/3154/.

CARIS, 2011, Geomatics Software Solutions, CARIS-HIPS and SIPS: CARIS, accessed April 12, 2011, at http://www.caris.com/products/hips-sips/.

Chesapeake Technology, Inc., 2011, SonarWiz.MAP +SBP: Chesapeake Technology Inc., accessed April 12, 2011, at http://www.chesapeaketech.com/prod-plussbp.html.

Cipriani, L.E., and Stone, G.W., 2001, Net longshore sediment transport and textural changes in beach sediments along the southwest Alabama and Mississippi barrier islands: Journal of Coastal Research, v. 17, p. 443-458.

Coda Octopus Group, Inc., 2011, Octopus F180 Attitude and Positioning System: Coda Octopus, accessed April 12, 2011, at http://www.codaoctopus.com/products/motionsensing/f180/index.asp.

Coleman, J.M., 1988, Dynamic changes and processes in the Mississippi River delta: Geological Society of America Bulletin, v. 100, p. 999-1015.

Danforth, W.W., 1997, Xsonar/ShowImage, a complete system for rapid sidescan sonar processing and display: U.S. Geological Survey Open-File Report 97-686, accessed April 12, 2011, at http://pubs.er.usgs.gov/usgspubs/ofr/ofr97686.

Doyle, L.J., and Sparks, T.N., 1980, Sediments on the Mississippi, Alabama, and Florida (MAFLA) continental shelf. Journal of Sedimentary Petrology, v. 50, p. 905-915.

EdgeTech, 2011, Sub-bottom profiling systems: EdgeTech, accessed April 12, 2011, at http://www.edgetech.com/productlinemarine.html.

ESRI, 2011, ArcGIS: ESRI, accessed April 12, 2011, at http://www.esri.com/products/index.html.

Flocks, J.G., Kelso, K.W., Twichell, D.C., Buster, N.A., and Baehr, J.N., 2011, Offshore sandshoal development and evolution of Petit Bois Pass, Mississippi-Alabama barrier islands, Mississippi, USA (extended abstract): Coastal Sediments 2011 Annual Meeting, Proceedings, Miami, Fla., 14 p. 
Flocks, J.G, Ferina, Nicholas, and Kindinger, J.L, in press, Recent geologic framework and geomorphology of the Mississippi-Alabama shelf, northern Gulf of Mexico, in Buster, N., and Holmes, C., eds., Gulf of Mexico: Origins, waters and biota, v. 3- Geology: Texas A\&M University Press, College Station, Tex., 475 p.

Forde, A.S., Dadisman, S.V., Flocks, J.G., Wiese, D.S., DeWitt, N.T., Pfeiffer, W.R., Kelso, K.W., and Thompson, P.R., in press, Archive of digital Chirp sub-bottom profile data collected during USGS cruises 10CCT01, 10CCT02, and 10CCT03, Mississippi and Alabama Gulf Islands, March and April 2010, U.S. Geological Survey Data Series Report, 7 DVD discs.

Frazier, D.E., 1967, Recent deltaic deposits of the Mississippi River: Their development and chronology: Transactions of the Gulf Coast Association of Geological Societies, v. 27, p. $287-$ 315.

Greene, D.L., Jr., Rodriguez, A.B., and Anderson, J.B, 2007, Seaward-branching coastal-plain and piedmont incised-valley systems through multiple sea-level cycles: Late Quaternary examples from Mobile Bay and Mississippi Sound, U.S.A.: Journal of Sedimentary Research, v. 77 , p. 139-158.

Halliburton, 2008, SeisVision Seismic Interpretation Software: Halliburton, accessed July 1, 2008, at http://www.geographix.com/solutions/geophysics/seismic-interpretationsystems/seisvision.aspx.

Hardin, J.D., Sapp, C.D., Emplaincourt, J.L., and Richter, K.E., 1976, Shoreline and bathymetric changes in the coastal area of Alabama, Geological Survey of Alabama Information Series 50, $125 \mathrm{p}$.

Kindinger, J.L., 1988, Seismic stratigraphy of the Mississippi-Alabama shelf and upper continental slope: Marine Geology, v. 83, p. 79-94.

Kindinger, J.L., 1989, Depositional history of the Lagniappe Delta, Northern Gulf of Mexico, Geo-Marine Letters, v. 9, p. 59-66.

Klein Associates, Inc., 2011, Klein System 3000 Sonar System: Klein Associates, Inc., accessed April 12, 2011, at http://www.1-3klein.com/3000series/3000.html.

McBride, R.A., Anderson, L.C., Tudoran, Andrei, and Roberts, H.H., 1999, Holocene stratigraphic architecture of a sand-rich shelf and the origin of linear shoals: northeastern Gulf of Mexico, SEPM Special Publication 64, p. 95-126.

McBride, R.A., Byrnes, M.R., and Hiland, M.W., 1995, Geomorphic response-type model for barrier coastlines: a regional perspective: Marine Geology, v. 126, p. 143-149.

McBride, R.A., Byrnes, M.R., Penland, S.J., Pope, D.L., and Kindinger, J.L., 1991, Geomorphic history, geologic framework, and hard mineral resources of the Petit Bois Pass area, Mississippi-Alabama [abs.]: Gulf Coast Section SEPM, Twelfth Annual Research Conference, Programs and Abstracts, p. 116-127.

McBride, R.A., Moslow, T.F., Roberts, H.H., and Diecchio, R.J., 2004, Late Quaternary geology of the northeastern Gulf of Mexico shelf: Sedimentology, depositional history, and ancient analogs of a major shelf sand sheet of the modern transgressive systems tract, in Anderson, 
J.B. , and Fillon, R.H., eds., Late Quaternary stratigraphic evolution of the northern Gulf of Mexico, SEPM Special Publication 79, p. 55-83.

Morton, R.A., 2008, Historical changes in the Mississippi-Alabama barrier-island chain and the roles of extreme storms, sea level, and human activities: Journal of Coastal Research, v. 24, p. 1587-1600.

Morton R.A., and Rogers, B.E., 2009, Depositional subenvironments of Gulf Islands National Seashore, Mississippi: U.S. Geological Survey Open-File Report 2009-1250, accessed April 12, 2011, at http://pubs.usgs.gov/of/2009/1250/.

Morton, R.A., 2010, First-order controls of extreme-storm impacts on the Mississippi-Alabama barrier-island chain: Journal of Coastal Research, v. 26, p. 635-648.

Norris, M.W., and Faichney, A.K., eds., 2002, SEG Y rev 1 Data Exchange format, SEG Technical Standards Committee, Release 1.0, May 2002: Tulsa, OK, Society of Exploration Geophysicists, 45 p., accessed April 12, 2011, at http://www.seg.org/resources/publications/misc/technical-standards.

Otvos, E.G. 1970, Development and migration of barrier islands, northern Gulf of Mexico: Geological Society of America Bulletin, v. 81, p. 241-246.

Otvos, E.G., 1981, Barrier island formation through nearshore aggradation - stratigraphic and field evidence: Marine Geology, v. 43, p. 195-243.

Otvos, E.G., and Carter, G.A., 2008, Hurricane degradation-barrier development cycles, northeastern Gulf of Mexico: Landform evolution and island chain history: Journal of Coastal Research, v. 24, no. 2, p. 463-478.

Otvos, E.G., and Giardino, M.J., 2004, Interlinked barrier chain and delta lobe development, northern Gulf of Mexico: Sedimentary Geology, v. 169, p. 47-73.

Pendleton, E.A., Baldwin, W.E., Danforth, W.W., Dewitt, N.T., Forde, A.S., Foster, D.S., Kelso, K.W., Pfeiffer, W. R., Turecek, A.M., Flocks, J.G., and Twichell, D.C., 2011, Geophysical data from offshore of the Gulf Islands National Seashore, Cat Island to Western Horn Island, Mississippi: U.S. Geological Survey Open-File Report 2010-1178.

Pfeiffer, W.R., Flocks, J.G., DeWitt, N.T., Forde, A.S., Kelso, Kyle, Thompson, P.R., and Wiese, D.S., in press, Archive of side scan sonar and swath bathymetry data collected during USGS cruise 10CCT02 offshore of Petit Bois Island, including Petit Bois Pass, Gulf Islands National Seashore, Mississippi, March 2010: U.S. Geological Survey Data Series 577, 1 DVD disc.

Rucker, J.B. and Snowden, J.O., 1989, Relict progradational beach ridge complex on Cat Island in Mississippi Sound: Transactions Gulf Coast Association of Geological Societies, v. 39, p. 531-539.

SIOSEIS, 2011, SIOSEIS -The introduction: SIOSEIS, accessed April 12, 2011, at http://sioseis.ucsd.edu/sioseis.html. 
Stapor, F.W., Jr., and Stone, G.W., 2004, A new depositional model for the buried 4000 yr BP New Orleans barrier: implications for sea-level fluctuations and onshore transport from a nearshore shelf source: Marine Geology, v. 204, p. 215-234.

Stockwell, J.W., Jr., and Cohen, J.K., 2007, The New SU User's Manual (version 3.3): Golden, Colo., Colorado School of Mines Center for Wave Phenomena, $153 \mathrm{p}$.

Systems Engineering and Assessment, Ltd (SEA), 2008, Swathplus - Wide Swath Bathymetry and Sidescan: SEA, Ltd., accessed April 12, 2011, at http://www.sea.co.uk/products/survey/SWATHplus.aspx.

Swift, D.J.P.., Sears, P.C., Bohlke, Brenda, and Hunt, Robert, 1978, Evolution of a shoal retreat massif, North Carolina shelf: Inferences from areal geology: Marine Geology, v. 27, p. 19-42.

Twichell, David, Pendleton, Elizabeth, Baldwin, Wayne, and Flocks, James, 2009, Subsurface control on seafloor erosional processes offshore of the Chandeleur Islands, Louisiana: GeoMarine Letters, v. 29, p. 349-358.

U.S. Army Corps of Engineers, 2009, Comprehensive plan and integrated programmatic environmental impact statement, Mississippi Coastal Improvements Program (MsCIP) Hancock, Harrison, and Jackson Counties, Mississippi: U.S. Army Corps of Engineers, accessed April 12, 2011, at http://www.sam.usace.army.mil/mscip/MsCIP_Comprehensive_Plan.htm.

Williams, SJ.., Arsenault, M.A., Buczkowski, B.J., Reid, J.A., Flocks, J.G., Kulp, M.A., Penland, Shea, and Jenkins, C.J., 2007, Surficial sediment character of the Louisiana offshore continental shelf region; a GIS compilation: U.S. Geological Survey Open-File Report 20061195, 1 CD-ROM, accessed April 12, 2011, at http://pubs.usgs.gov/of/2006/1195/. 
For more information concerning this report, contact

Director

U.S. Geological Survey

Woods Hole Coastal and Marine Science Center

384 Woods Hole Road

Quissett Campus

Woods Hole, MA 02543-1598

WHSC_science_director@usgs.gov

508-548-8700 or 508-457-2200

or visit our Web site at:

http://woodshole.er.usgs.gov 
